\title{
SIMULATION OF GROUND-WATER FLOW IN SOUTHEASTERN COASTAL PLAIN CLASTIC AQUIFERS IN EORGIA AND ADJACENT PARTS OF ALABAMA AND SOUTH CAROLINA
}

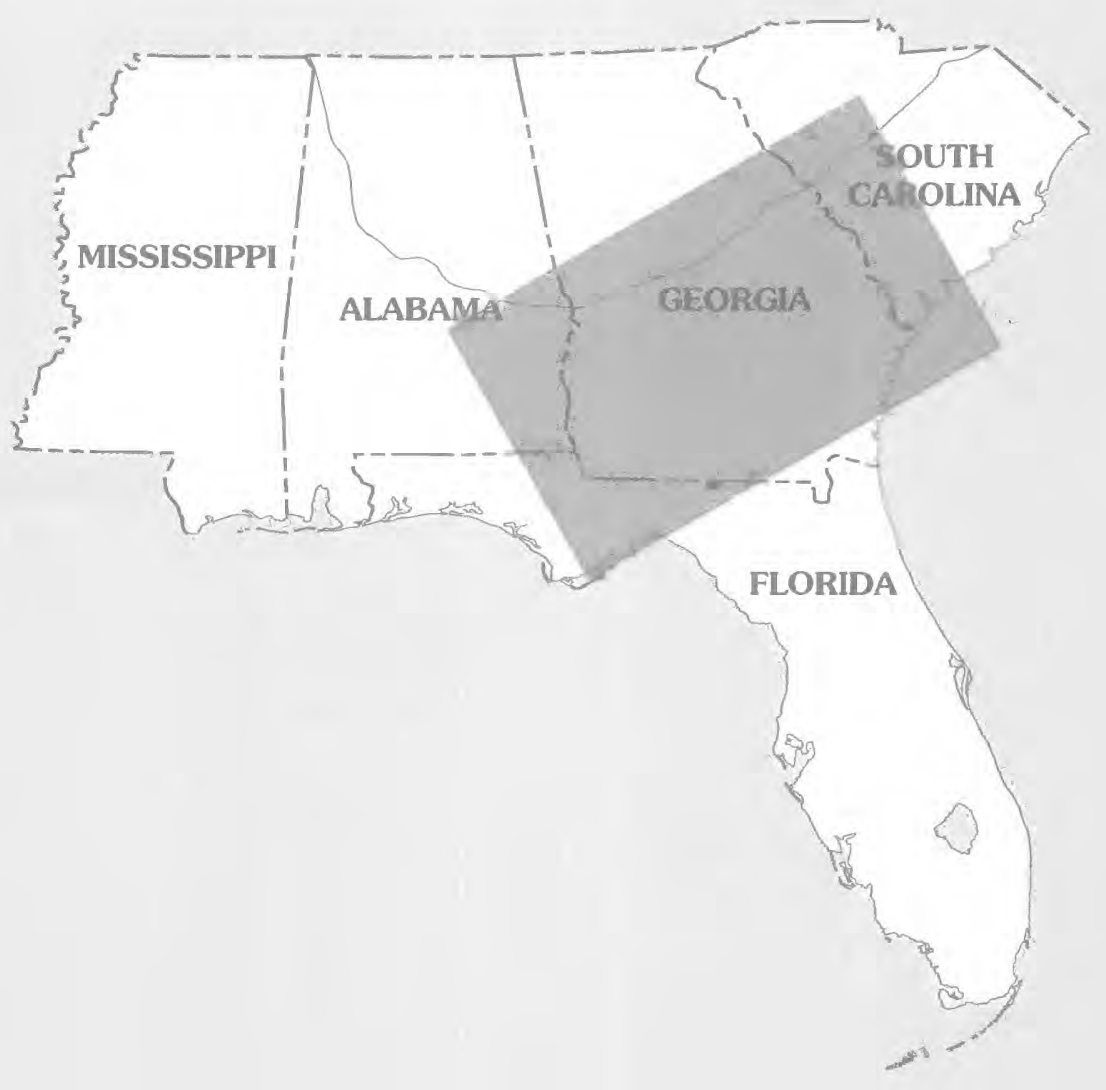




\section{AVAILABILITY OF BOOKS AND MAPS OF THE U.S. GEOLOGICAL SURVEY}

Instructions on ordering publications of the U.S. Geological Survey, along with prices of the last offerings, are given in the currentyear issues of the monthly catalog "New Publications of the U.S. Geological Survey." Prices of available U.S. Geological Survey publications released prior to the current year are listed in the most recent annual "Price and Availability List." Publications that may be listed in various U.S. Geological Survey catalogs (see back inside cover) but not listed in the most recent annual "Price and Availability List" may be no longer available.

Order U.S. Geological Survey publications by mail or over the counter from the offices given below.

\section{BY MAIL}

\section{Books}

Professional Papers, Bulletins, Water-Supply Papers, Techniques of Water-Resources Investigations, Circulars, publications of general interest (such as leaflets, pamphlets, booklets), single copies of Preliminary Determination of Epicenters, and some miscellaneous reports, including some of the foregoing series that have gone out of print at the Superintendent of Documents, are obtainable by mail from

\section{U.S. Geological Survey, Information Services Box 25286, Federal Center, Denver, CO 80225}

Subscriptions to Preliminary Determination of Epicenters can be obtained ONLY from the

\section{Superintendent of Documents Government Printing Office Washington, DC 20402}

(Check or money order must be payable to Superintendent of Documents.)

\section{Maps}

For maps, address mail orders to

U.S. Geological Survey, Information Services Box 25286, Federal Center, Denver, CO 80225

\section{OVER THE COUNTER}

\section{Books and Maps}

Books and maps of the U.S. Geological Survey are available over the counter at the following U.S. Geological Survey Earth Science Information Centers (ESIC's), all of which are authorized agents of the Superintendent of Documents:

- ANCHORAGE, Alaska-Rm. 101, 4230 University Dr.

- LAKEWOOD, Colorado-Federal Center, Bldg. 810

- MENLO PARK, California-Bldg. 3, Rm. 3128, 345 Middlefield Rd.

- RESTON, Virginia-USGS National Center, Rm. 1C402, 12201 Sunrise Valley Dr.

- SALT LAKE CITY, Utah-Federal Bldg., Rm. 8105, 125 South State St.

- SPOKANE, Washington-U.S. Post Office Bldg., Rm. 135, West 904 Riverside Ave.

- WASHINGTON, D.C.-Main Interior Bldg., Rm. 2650, 18th and C Sts., NW.

\section{Maps Only}

Maps may be purchased over the counter at the following U.S. Geological Survey office:

- ROLLA, Missouri-1400 Independence Rd. 
Simulation of Ground-Water Flow in Southeastern Coastal Plain Clastic Aquifers in Georgia and Adjacent Parts of Alabama and South Carolina

By ROBERT E. FAYE and GREGORY C. MAYER

REGIONAL AQUIFER-SYSTEM ANALYSIS-

SOUTHEASTERN COASTAL PLAIN

U.S. GEOLOGICAL SURVEY PROFESSIONAL PAPER 1410-F

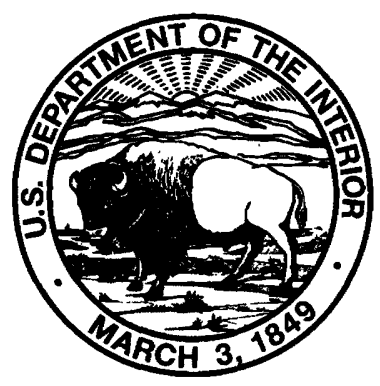




\section{U.S. DEPARTMENT OF THE INTERIOR \\ BRUCE BABBITT, Secretary}

\section{U.S. GEOLOGICAL SURVEY}

Gordon P. Eaton, Director

Any use of trade, product, or firm names in this publication is for descriptive purposes only and does not imply endorsement by the U.S. Government.

\section{Library of Congress Cataloging in Publication Data}

Faye, Robert E

Simulation of ground-water flow in Southeastern Coastal Plain clastic aquifers in Georgia and adjacent parts of Alabama and South Carolina / by Robert E. Faye and Gregory C. Mayer

p. cm. - ( U.S. Geological Survey professional paper ; 1410-F) (Regional aquifer-system analysis - Southeastern Coastal Plain) Includes bibliographical references.

1. Gorundwater flow - Southern States - Computer simulation. I. Mayer, Gregory C. II. Title. III. Series. IV. Series:

GB1197.7.F39 1996

$551.49^{\prime} 0975-\mathrm{dc} 20$

ISBN 0-607-87031-1

For sale by U.S. Geological Survey

Branch of Information Services, Box 25286,

Federal Center, Denver, CO 80225 


\section{FOREWORD}

\section{THE REGIONAL AQUIFER-SYSTEM ANALYSIS PROGRAM}

The RASA Program represents a systematic effort to study a number of the Nation's most important aquifer systems, which, in aggregate, underlie much of the country and which represent an important component of the Nation's total water supply. In general, the boundaries of these studies are identified by the hydrologic extent of each system and, accordingly, transcend the political subdivisions to which investigations have often arbitrarily been limited in the past. The broad objective for each study is to assemble geologic, hydrologic, and geochemical information, to analyze and develop an understanding of the system, and to develop predictive capabilities that will contribute to the effective management of the system. The use of computer simulation is an important element of the RASA studies to develop an understanding of the natural, undisturbed hydrologic system and the changes brought about in it by human activities and to provide a means of predicting the regional effects of future pumping or other stresses.

The final interpretive results of the RASA Program are presented in a series of U.S. Geological Survey Professional Papers that describe the geology, hydrology, and geochemistry of each regional aquifer system. Each study within the RASA Program is assigned a single Professional Paper number beginning with Professional Paper 1400.

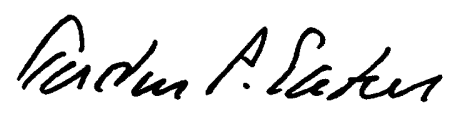

Gordon P. Eaton Director 



\section{CONTENTS}

Foreword

Abstract.

Introduction

Purpose and Scope

Description of Study Area.

Physiography and Drainage.

Climate and Runoff.

Land Use....

Data Sources and Previous Work

Geologic and Geohydrologic Frameworks

Geologic Framework

Geohydrologic Framework

Subregional Ground-Water Flow

Conceptual Model

Hydrologic Budget
Page Page

III $\mid$ Simulation of Ground-Water Flow ................................. F29

F1 Model Description............................................ 29

Boundary and Initial Conditions ............................... $\quad 30$

Hydrologic Input Data.......................................... 38

Calibration ....................................................... 38

Predevelopment (Steady-State) Simulations of

Ground-Water Flow

44

Sensitivity Analyses of Steady-State Model............. $\quad 52$

Simulation of Transient Ground-Water Flow ............ $\quad 53$

Sensitivity Analysis of Transient Model................... 69

Linkage with Floridan Regional Aquifer-System

Analysis Models .................................. $\quad 69$

Summary and Conclusions............................................ 71

References Cited .................................................... $\quad 72$

\section{ILLUSTRATIONS}

[Plates are in a separate case]

Plate 1. Correlation chart of chronostratigraphic, formational, and regional and subregional geohydrologic units.

2. Geohydrologic section $A-A^{\prime}$, Macon County, Alabama, to Jackson County, Florida.

3. Geohydrologic section $B-B^{\prime}$, Bibb County to Echols County, Georgia.

4. Geohydrologic section $C-C^{\prime}$, Aiken County to Beaufort County, South Carolina.

5-9. Maps showing simulated predevelopment potentiometric surface of model layer-
5. A2a2 (Tallahatta-Gordon aquifer).
6. A3a1 (Clayton-Ellenton aquifer).
7. A3a2 (Providence Sand-Peedee aquifer).
8. A3a3 (Eutaw-Midville aquifer).
9. A4a1 (upper Atkinson-upper Tuscaloosa aquifer).

10. Maps showing ground-water use in the Georgia subregion, 1900-80.

11. Hydrographs of observed and simulated water levels.

12-16. Maps showing simulated potentiometric surface of model layer-

12. A2a2 (Tallahatta-Gordon aquifer), 1980.

13. A3a1 (Clayton-Ellenton aquifer), 1980.

14. A3a2 (Providence Sand-Peedee aquifer), 1980.

15. A3a3 (Eutaw-Midville aquifer), 1980.

16. A4a1 (upper Atkinson-upper Tuscaloosa aquifer), 1980. 


\section{CONTENTS}

FIGURE 1. Map showing study area, drainage network, major Coastal Plain structural features, stream data-collection sites, geohydrologic section lines, and flow model boundary

2, 3. Maps showing-

2. Mean annual rainfall, $1941-70$

3. Mean annual runoff, 1941-70

4-11. Maps showing altitude at the-

4. Base of Coastal Plain sediments.

5. Top of Eaglefordian sediments

6. Top of Navarroan sediments

7. Top of Jacksonian sediments

8. Top of the Tallahatta-Gordon aquifer

9. Top of the Tuscahoma-Fishburne confining unit

10. Top of the upper Atkinson-upper Tuscaloosa aquifer

11. Top of the middle Atkinson confining unit

12, 13. Maps showing estimated potentiometric surface $(1940-55)$ for the-

12. Combined Clayton-Ellenton, Providence Sand-Peedee, and Eutaw-Midville aquifers near the Inner Coastal Plain Margin and the Savannah River, Georgia and South Carolina ...

13. Tallahatta-Gordon aquifer near the Inner Coastal Plain Margin and the Savannah River, Georgia and South Carolina.

14. Cross-sectional model grid, geohydrology, stream-discharge locations, and selected qualitative flow lines

15. Map showing areal distribution and predevelopment potentiometric surface of specified-head, source-sink model layer A2a1 (Barnwell-Upper Floridan aquifer).

16. Map showing model grid discretization and grid numbering scheme.....

17-21. Maps showing extent of model layer, area where direct recharge is possible, and boundary conditions:

17. Model layer A2a2 (Tallahatta-Gordon aquifer)

18. Model layer A3a1 (Clayton-Ellenton aquifer)

19. Model layer A3a2 (Providence Sand-Peedee aquifer)

20. Model layer A3a3 (Eutaw-Midville aquifer)

21. Model layer A4a1 (upper Atkinson-upper Tuscaloosa aquifer)

22-26. Maps showing calibrated transmissivity distribution for model layer-

22. A2a2 (Tallahatta-Gordon aquifer)

23. A3a1 (Clayton-Ellenton aquifer)

24. A3a2 (Providence Sand-Peedee aquifer)

25. A3a3 (Eutaw-Midville aquifer).

26. A4a1 (upper Atkinson-upper Tuscaloosa aquifer)

27-31. Maps showing calibrated leakance distribution for model layer-

27. A2c1 (Lisbon-McBean confining unit).

28. C2 (Tuscahoma-Fishburne confining unit)

29. A3c1 (Providence Sand-Peedee confining unit)

30. A3c2 (Ripley-Black Creek confining unit).

31. C3 (Eutaw-Cape Fear confining unit).

32. Diagram showing simulated components of the predevelopment water budget, by model layer .....................................50

33-37. Maps showing calibrated storativity distribution for model layer-

33. A2a2 (Tallahatta-Gordon aquifer)

34. A3a1 (Clayton-Ellenton aquifer).....

35. A3a2 (Providence Sand-Peedee aquifer)

36. A3a3 (Eutaw-Midville aquifer).

37. A4a1 (upper Atkinson-upper Tuscaloosa aquifer)

38. Map showing potentiometric surface of specified-head, source-sink model layer A2a1 (Barnwell-Upper Floridan aquifer), 1980

39. Diagram showing simulated components of the 1980 water budget, by model layer

13

14

15

ps showing simulated water-level decline for model layer-

40. A2a2 (Tallahatta-Gordon aquifer), 1900-80

41. A3a1 (Clayton-Ellenton aquifer), 1900-80 .

42. A3a2 (Providence Sand-Peedee aquifer), 1900-80

43. A3a3 (Eutaw-Midville aquifer), 1900-80

44. A4a1 (upper Atkinson-upper Tuscaloosa aquifer), 1900-80

45. Map showing areas common to Floridan Regional Aquifer-System Analysis models 


\section{TABLES}

TABLE 1. Relation of geohydrologic nomenclature and model layers used for regional and Georgia subregional Regional

Aquifer-System Analysis studies.

F

3. Selected predevelopment ground-water net rech

4. Summary of mean annual ground-water discharge to regional drains and corresponding net gain between gaging stations .

5. Summary of mean annual ground-water discharge to regional drains from combined intermediate and regional flow regimes based on drought streamflows .....

6. Components of the subregional ground-water budget

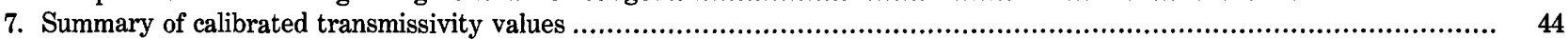

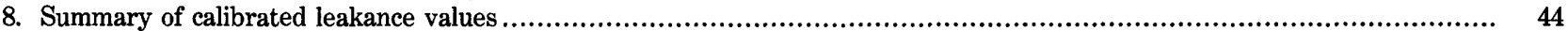

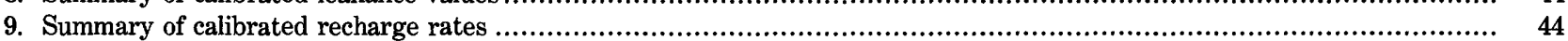

10. Summary of statistical evaluations of the simulated predevelopment potentiometric surfaces .................................... 51

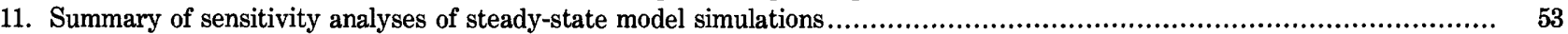

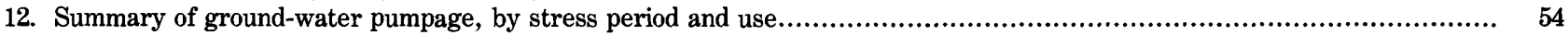

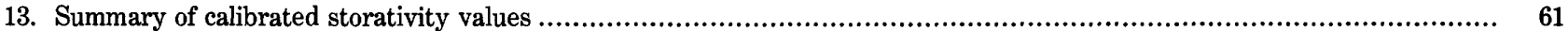

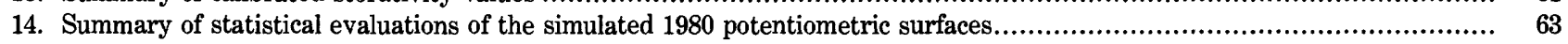

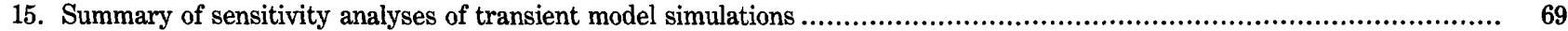

\section{CONVERSION FACTORS AND VERTICAL DATUM}

For use of readers who prefer to use International System (SI) units, rather than the inch-pound terms used in this report, the following conversion factors are provided:

\begin{tabular}{rll}
\hline Multiply inch-pound units & By & To obtain SI units \\
\hline inch (in.) & 25.4 & millimeter $(\mathrm{mm})$ \\
foot $(\mathrm{ft})$ & 0.3048 & meter $(\mathrm{m})$ \\
mile $(\mathrm{mi})$ & 1.609 & kilometer $(\mathrm{km})$ \\
square mile $\left(\mathrm{mi}^{2}\right)$ & 2.590 & square kilometer $\left(\mathrm{km}^{2}\right)$ \\
square foot per day $\left(\mathrm{ft}^{2} / \mathrm{d}\right)$ & 0.09290 & square meter per $\mathrm{day}\left(\mathrm{m}^{2} / \mathrm{d}\right)$ \\
cubic foot per second $\left(\mathrm{ft}^{3} / \mathrm{s}\right)$ & 0.02832 & cubic meter per second $\left(\mathrm{m}^{3} / \mathrm{s}\right)$ \\
cubic foot per second & 0.01093 & cubic meter per second per \\
per square mile $\left[\left(\mathrm{ft}^{3} / \mathrm{s}\right) / \mathrm{mi}^{2}\right]$ & & square kilometer $\left[\left(\mathrm{m}^{3} / \mathrm{s}\right) / \mathrm{km}^{2}\right]$ \\
million gallons per day $(\mathrm{Mgal} / \mathrm{d})$ & 0.04381 & cubic meters per second $\left(\mathrm{m}^{3} / \mathrm{s}\right)$ \\
\hline
\end{tabular}

Temperature in degrees Fahrenheit $\left({ }^{\circ} \mathrm{F}\right)$ can be converted to degrees Celsius $\left({ }^{\circ} \mathrm{C}\right)$ as follows:

$$
{ }^{\circ} \mathrm{F}=1.8^{\circ} \mathrm{C}+32
$$

Sea level: In this report "sea level" refers to the National Geodetic Vertical Datum of 1929 (NGVD of 1929) - a geodetic datum derived from a general adjustment of the first order nets of both the United States and Canada, formerly called "Mean Sea Level of 1929." 



\title{
SIMULATION OF GROUND-WATER FLOW IN SOUTHEASTERN COASTAL PLAIN CLASTIC AQUIFERS IN GEORGIA AND ADJACENT PARTS OF ALABAMA AND SOUTH CAROLINA
}

\author{
By Robert E. Faye and Gregory C. Mayer
}

\begin{abstract}
A coarse-grid, digital model was used to simulate ground-water flow in five areally extensive, generally clastic aquifers within a $60,000-$ square-mile area of the Coastal Plain of Georgia and contiguous parts of Alabama and South Carolina. Aquifers investigated are the Tallahatta-Gordon, the Clayton-Ellenton, the Providence SandPeedee, the Eutaw-Midville, and the upper Atkinson-upper Tuscaloosa. The uppermost aquifer was simulated as a specified-head, source-sink layer and represents the Barnwell-Upper Floridan aquifer. The downgradient boundary for each model layer was specified as the limit of freshwater or was arbitrarily defined by a specified-head boundary. The base of the model corresponds either to the base of Coastal Plain sediments or to the top of the middle Atkinson confining unit. Western and eastern model boundaries were simulated as a line of specified-head or zero flow, depending on aquifer and location.

Regional components of ground-water flow were of major interest to this study and composed about 12 percent of total ground-water flow through the major clastic Coastal Plain aquifers. Model investigations included simulations of predevelopment and 1980 conditions. Simulated predevelopment (circa 1900) direct recharge to the model was about 670 cubic feet per second. This quantity represents net infiltration of precipitation to the regional flow regime. Simulated predevelopment vertical leakage from the source-sink layer was about 570 cubic feet per second. Simulated predevelopment discharge from the regional flow regime occurred to major rivers at about 830 cubic feet per second. Upward leakage to the Barnwell-Upper Floridan aquifer was about 370 cubic feet per second, and net discharge to specified heads along boundaries was about 40 cubic feet per second. Simulated predevelopment flow rates were at steady state.

Transient flow conditions were simulated for the period 1900-80. After 80 years of simulated ground-water pumping, ground-water discharge to major rivers was reduced to about 670 cubic feet per second, or about 19 percent below predevelopment rates. Related reductions in aquifer storage were about 22 cubic feet per second. Simulated downward leakage from the Barnwell-Upper Floridan aquifer increased to about 725 cubic feet per second, or about 27 percent over the predevelopment rate. Corresponding upward leakage to the Barnwell-Upper Floridan aquifer was about 430 cubic feet per second during 1980. Net boundary discharges decreased from 44 cubic feet per second out of the model to about 3 cubic feet per second into the model. Simulated rates of direct recharge during transient simulations were maintained at the predevelopment rate of about 670 cubic feet per second. Total mean annual pumping for the period 1976-80 was about
\end{abstract}

370 cubic feet per second. Major areas of water-level declines were simulated in the Tallahatta-Gordon aquifer in southeastern Georgia; the Clayton-Ellenton aquifer in Houston County, Alabama; the Clayton-Ellenton and Providence Sand-Peedee aquifers in southwestern Georgia; and the Clayton-Ellenton aquifer in Hampton County, South Carolina.

\section{INTRODUCTION}

The U.S. Geological Survey has undertaken a study of 28 regional aquifer systems in the United States. These studies, which began in 1978, are collectively termed the Regional Aquifer-System Analysis (RASA) Program. The general objectives of RASA are to define the regional hydrogeology and to establish a framework of background information and data that can be used for assessment of regional and local ground-water resources (Sun, 1986). The Southeastern Coastal Plain regional aquifer system includes about 130,000 square miles $\left(\mathrm{mi}^{2}\right)$ of the Southeastern U.S. Coastal Plain in South Carolina, Georgia, Alabama, and Mississippi (Miller and Renken, 1988). The aquifer systems of this area are composed largely of Cretaceous and Tertiary clastic sediments. The Southeastern Coastal Plain RASA was divided into several subregional projects to facilitate areally specific hydrologic investigations. The Georgia subregion, which is the focus of this report, includes about $60,000 \mathrm{mi}^{2}$ of the Georgia Coastal Plain and adjacent parts of Alabama and South Carolina (fig. 1).

This report summarizes the results of RASA investigations of areally extensive ground-water flow within major aquifers of the Georgia subregion. Other reports, which summarize the results of similar Southeastern Coastal Plain RASA investigations, are the other chapters of U.S. Geological Survey Professional Paper 1410. 


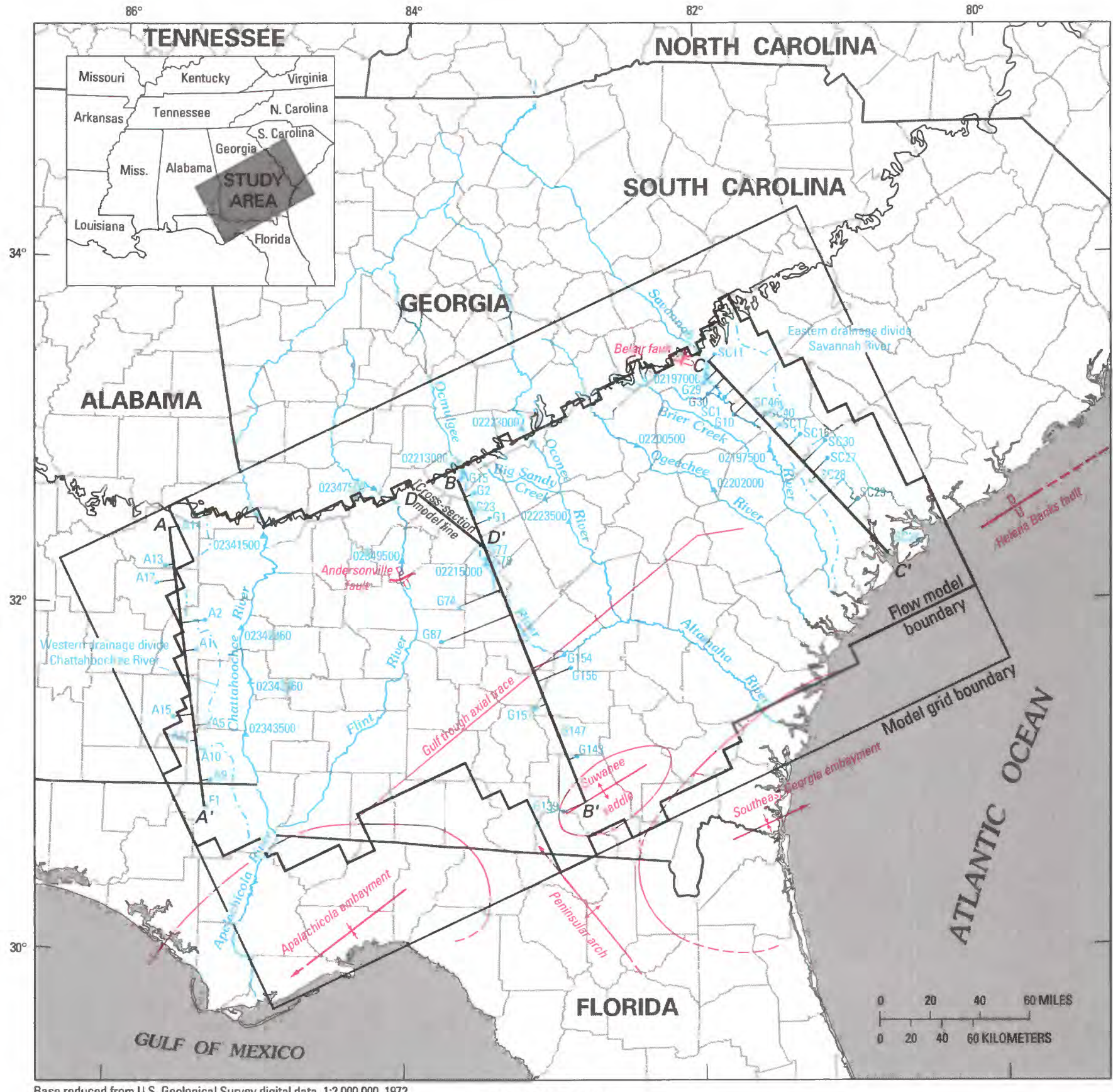

Base reduced from U.S. Geological Survey digital data, 1:2,000,000, 1972

U - - Fault-Dashed where approximately located. $\mathrm{U}$, upthrown side. $\mathrm{D}$, downthrown side

\section{EXPLANATION}

\section{Shyon Inner margin of Coastal Plain sediments}

- Limit of structural feature-Dashed where approximately located

Axial trace of structural feature-Large arrow indicates direction of plunge. Dashed where approximately located

$\downarrow-$ Axis of positive feature

A $\quad A^{\prime}$ Line of geohydrologic section

+-- Axis of negative feature

\section{Drainage divide}

Site and number of periodic stream discharge measurement

Site and number of continuous-record stream gaging station

Control site for geohydrologic section

Figure 1. - Study area, drainage network, major Coastal Plain structural features, stream data-collection sites, geohydrologic section lines, and flow model boundary. County boundaries are shown here; county names are shown on plate 5 . 


\section{PURPOSE AND SCOPE}

The principal purposes of this report are to describe and evaluate the results of investigations of areally extensive ground-water flow within major clastic aquifers of the Georgia subregion. Specific components of this report include descriptions of the following:

1. calibration of a digital computer model that simulates ground-water flow in vertically contiguous subregional aquifers, and

2. application of this model to quantitatively describe conditions of predevelopment (circa 1900) and modern (1980) subregional ground-water flow.

\section{DESCRIPTION OF STUDY AREA}

The Georgia subregion includes, from west to east, that part of the Southeastern Coastal Plain generally bounded by the drainage divide of the Chattahoochee River in eastern Alabama and the drainage divide of the Savannah River in South Carolina. North-to-south, the subregion extends south from the Inner Margin of the Coastal Plain to approximately the Florida State line (fig. 1).

\section{PHYSIOGRAPHY AND DRAINAGE}

The Georgia subregion is located within the Coastal Plain physiographic province of the Southeastern United States and includes parts of both the Atlantic and Gulf Coastal Plains. The seaward margin of the subregion contains the offshore coastal islands, tidal marshes, coastal terraces, and lowland and tidally affected areas that extend inland as much as 85 miles (mi). Maximum land-surface altitude in this part of the subregion is about 250 feet ( $\mathrm{ft}$ ). The northern boundary of the subregion is marked by the Inner Margin of Coastal Plain sediments. By definition, this margin is the geologic boundary between Coastal Plain unconsolidated sediments and consolidated Piedmont rocks. In the Georgia subregion, the Inner Coastal Plain Margin also approximately defines the Fall Line, which is the boundary between the Coastal Plain and Piedmont physiographic provinces. The landscape near and somewhat south of the Inner Coastal Plain Margin is characterized, from east to west, by alternating river valleys and high hills. Maximum land-surface altitude in this part of the subregion is about $700 \mathrm{ft}$.

The highest order streams that drain the Georgia subregion (fig. 1) are herein referred to as regional drains, and all head north of the subregion in the Blue Ridge or Piedmont physiographic provinces. The westernmost regional drain is the Chattahoochee River, which flows southward and forms all of the GeorgiaAlabama State boundary within the subregion. Near the
Georgia-Florida State boundary, the Flint River, which drains much of southwestern Georgia, joins the Chattahoochee River to form the Apalachicola River. The Apalachicola River flows directly southward across the Florida panhandle and discharges to the Gulf of Mexico. The major streams that drain the central part of the Georgia subregion are the Ocmulgee and Oconee Rivers, which combine in south-central Georgia to form the Altamaha River. The Altamaha River flows eastward and southeastward to discharge to the Atlantic Ocean near Brunswick, Ga. The Ogeechee River heads just north of the Coastal Plain in eastern Georgia and flows southeastward to the Atlantic Ocean. The Savannah River is the easternmost regional drain, and it forms most of the Georgia-South Carolina State boundary. The Savannah River also flows southeastward and discharges to the Atlantic Ocean near Savannah, Ga. Brier Creek, a major tributary to the Savannah River, heads in the Piedmont physiographic province in Warren County, Ga., and flows southeastward to join the Savannah River near Sylvania, Ga., in northern Screven County (fig. 1).

\section{CLIMATE AND RUNOFF}

The climate of the study area is characterized by short, mild winters and hot, humid summers. Winter temperatures generally are above freezing but occasionally drop below $20^{\circ} \mathrm{F}$. Daily summer temperatures commonly are above $90^{\circ} \mathrm{F}$, and temperatures of $100^{\circ} \mathrm{F}$ are not unusual. The frost-free growing season typically is about 240 days and extends from about mid-March to mid-November. Mean annual air temperature is about $66^{\circ} \mathrm{F}$ (U.S. Department of Agriculture, 1982).

Precipitation in the Georgia subregion occurs almost entirely as rainfall and ranges from about 44 to 56 inches per year (in/yr) (U.S. Study Commission-Southeast River Basins, 1963; Bingham, 1982; Carter and Stiles, 1983). Mean annual rainfall generally increases from north to south across the subregion and decreases from the eastern and western peripheries of the subregion toward the east-central part of the Coastal Plain of Georgia (fig. 2).

Annual runoff in the Georgia subregion is highly variable spatially and ranges from about 0.8 to 1.7 cubic feet per second per square mile $\left[\left(\mathrm{ft}^{3} / \mathrm{s}\right) / \mathrm{mi}^{2}\right]$ (fig. 3). Runoff is most variable in the southwestern part of the subregion, where rapidly increasing seaward changes in runoff may be the result of tropical storm- and hurricanegenerated precipitation in coastal areas. Runoff is high in southwestern Georgia between Sumter County and the Inner Coastal Plain Margin and in central Georgia in the vicinity of Dodge County. Runoff is low near the Chattahoochee River in the vicinity of Bullock County, Ala., and Stewart County, Ga. 


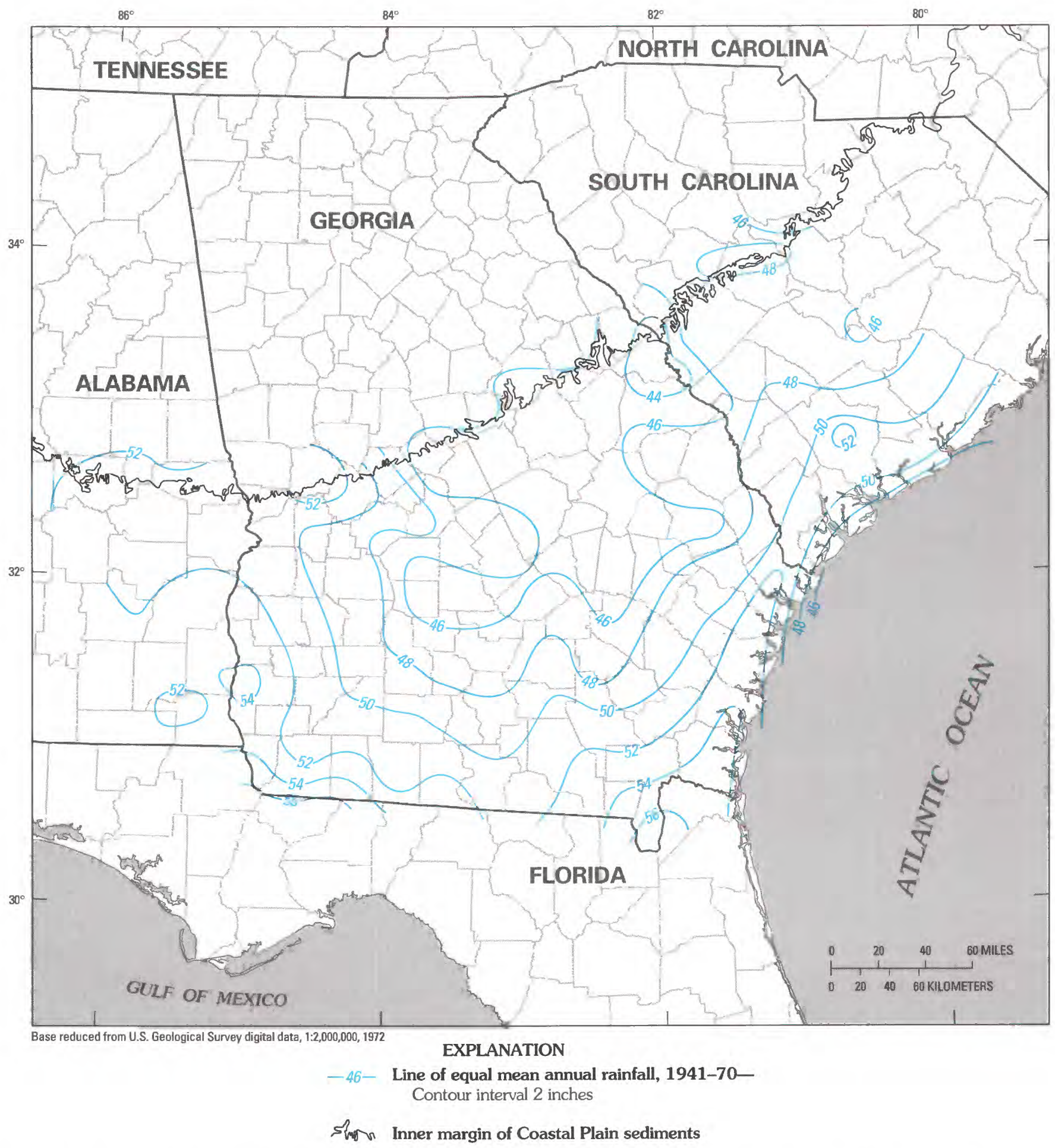

FiguRE 2.-Mean annual rainfall, 1941-70 (modified from Bingham, 1982; Carter and Stiles, 1983; South Carolina Water Resources Commission, 1983). 


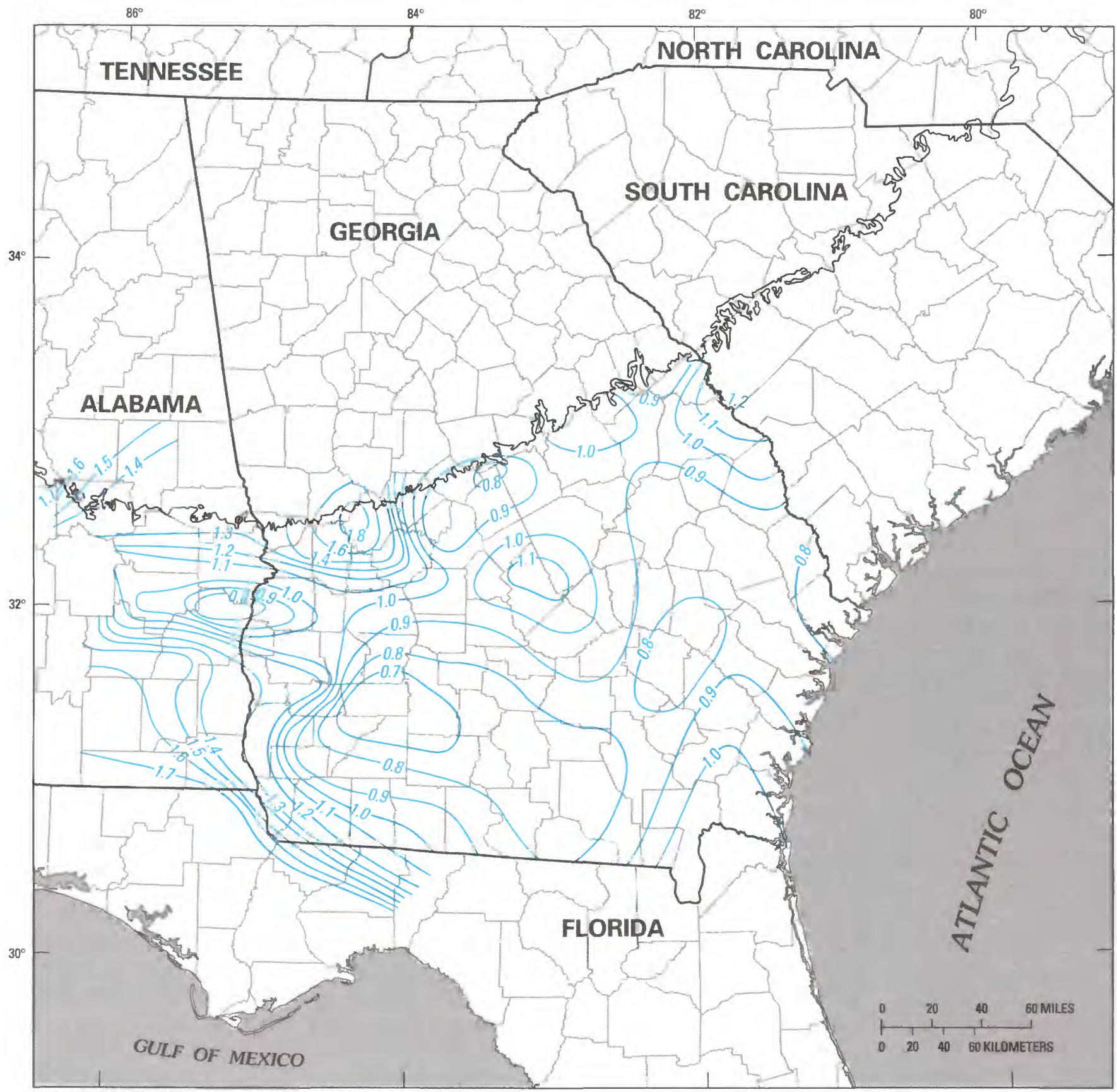

Base reduced from U.S. Geological Survey digital data, 1:2,000,000, 1972 EXPLANATION
ENAN

- 0.9- Line of equal mean annual runoff, 1941-70 - Contour interval, in cubic feet per second per square mile, is variable

sforn Inner margin of Coastal Plain sediments

FiguRE 3.-Mean annual runoff, 1941-70 (Alabama contours modified from unpublished U.S. Geological Survey map; Georgia contours modified from Carter and Stiles, 1983). 


\section{LAND USE}

Land area within the Georgia subregion largely is occupied by forests and farm lands. Minor areas are occupied by small cities, Federal installations, mines, and industries. Prominent cities are near the coast and near the Inner Coastal Plain Margin and include Columbus, Macon, Milledgeville, Augusta, and Savannah in Georgia; Phenix City, Ala.; and Aiken, S.C. Cities within the interior of the Coastal Plain include Eufaula and Dothan in eastern Alabama and Americus and Albany in southwestern Georgia. Mining of kaolin and other clay minerals is an important industry in eastern Georgia and western South Carolina near the Inner Coastal Plain Margin. Large Federal installations within the subregion include Fort Benning near Columbus, Ga.; Fort Gordon near Augusta, Ga.; and the Savannah River Site (SRS) near Aiken, S.C.

Land-use data for the entire Georgia subregion are unavailable. Data listed by the U.S. Department of Agriculture $(1982,1985)$ are inclusive of the northern two-thirds of the Georgia Coastal Plain and, for this study, are considered representative of the entire Georgia subregion. The total area described by the U.S. Department of Agriculture $(1982,1985)$ is approximately 15.4 million acres. Of this area, approximately 55 percent is forest, 32 percent is crop land, 6 percent is pasture, and 7 percent accounts for urban, water, mining, transportation, and other minor land usages.

\section{DATA SOURCES AND PREVIOUS WORK}

Basic hydrologic data used in this study include ground-water levels and water-quality analyses; wellsite inventories and descriptions; and records of streamflow, water-use, and aquifer tests. Hydrologic data were obtained largely from unpublished sources, including the files of the U.S. Geological Survey; the Georgia Geologic Survey; the Georgia Environmental Protection Division; the South Carolina Water Resources Commission; the U.S. Department of Energy; and numerous industries, well drillers, and municipalities.

Ground-water levels that approximate predevelopment conditions in the Georgia Coastal Plain were obtained from McCallie $(1898,1908)$ and Stephenson and Veatch (1915). Comprehensive, historical water-level data pertinent to the northern part of the Georgia Coastal Plain were listed by LaMoreaux (1946), LeGrand and Furcron (1956), and LeGrand (1961, 1962). Historical ground-water-level data within the northern Coastal Plain of Alabama were published by Smith (1904) and Carlston (1944). Historical ground-water levels in the South Carolina Coastal Plain were obtained from Cooke (1936) and Siple (1946). Water-level data pertinent to
Aiken, Barnwell, and Allendale Counties in South Carolina were published in Siple (1955?). Historical data generally refer to the period $1939-55$ and were utilized extensively in the development of preliminary maps showing predevelopment and historic potentiometric surfaces. Miscellaneous water-level data applied to these potentiometric maps were published in Owen (1959, 1963a), Wait (1960a,b,c, 1963), Stringfield (1966), and Stewart (1973). Historical ground-water levels used indirectly in the development of potentiometric maps were obtained from Warren (1945), Wait (1963), and Owen (1963b), and were shown on maps by Counts and Donsky (1963), Callahan (1964), McCollum and Counts (1964), Sever (1965a,b, 1966), Vorhis (1972), Counts and Krause (1976), Hayes (1979), Johnston and others $(1980,1981)$, Watson (1981), and Vincent (1982).

Recent measurements of ground-water levels in the northern part of the Georgia Coastal Plain were listed by Clarke and others $(1983,1984,1985)$ and Brooks and others (1985). Faye and Prowell (1982) showed several interpretations of predevelopment potentiometric maps for aquifers of Cretaceous and Tertiary age in the vicinity of the Savannah River in Georgia and South Carolina. Hicks and others (1981) showed recent potentiometric maps for equivalent aquifers in the vicinity of Albany in southwestern Georgia. Similar potentiometric maps for Richmond and Burke Counties in Georgia were shown by Gorday (1985).

Recent ground-water levels in eastern Alabama were listed by county by Scott (1960, 1962a,b, 1964), Newton and others (1966), Scott and others (1967, 1968, 1984), Newton, Golden, and others (1968), Newton, McCain, and Avrett (1968), Shamburger and others (1968), Scott and Lines (1972), Davis (1980), and Moffett and others (1985). Measurements in these reports generally span the period 1960-70. A map showing the recent (1983) potentiometric surface of the basal Tertiary aquifer in the vicinity of Fort Rucker in southeastern Alabama is shown in a report by Scott and others (1984).

In western South Carolina, recent water-level data were reported by Christl (1964), Siple (1975), Cahill (1982), and Bennett and others (1983). These data largely are site specific and pertain only to parts of Aiken, Barnwell, and Orangeburg Counties, S.C.

Hydraulic-characteristic data used in this study are based on aquifer tests summarized by Faye and McFadden (1986). Numerous unpublished specific-capacity data also were used to estimate aquifer transmissivity. Published specific-capacity data for eastern Alabama were listed by Scott (1960, 1962a,b, 1964), Scott and others (1967, 1968), Newton, Golden, and others (1968), Newton, McCain, and Avrett (1968), Shamburger and others (1968), and Scott and Lines (1972). Similar data in Georgia were summarized by Clarke and others (1983, 
1984, 1985) and Brooks and others (1985). In South Carolina, specific-capacity data were reported by Siple (1955?, 1975).

Water use at about the beginning of the century at several municipalities in the Georgia Coastal Plain was reported by McCallie $(1898,1908)$ and Stephenson and Veatch (1915). Similar data at about 1940 for the northern part of the Alabama Coastal Plain and the South Carolina Coastal Plain were included in Carlston (1944) and South Carolina State Planning Board (1944), respectively. Municipal water-use data for the southeastern Alabama Coastal Plain at about 1945 were reported by Carter and Williams (1949). Municipal and industrial water-use data for 1960 for the entire study area were included in U.S. Study Commission-Southeast River Basins (1963). Recent water-use data for Alabama for municipal, industrial, and irrigation purposes were reported by Baker and others (1982). Similarly, recent water-use data for the Coastal Plain of South Carolina were listed in reports by South Carolina Water Resources Commission (1971, 1977). Published references to recent water use in Georgia are more numerous and include those by Thomson and others (1956), Carter and Johnson (1974), Pierce and others (1982, 1984), Clarke and others $(1983,1984,1985)$, and Brooks and others (1985). In addition, numerous unpublished data on municipal water use for Georgia were obtained for the period 1955-70 from Insurance Services of Georgia.

A subregional hydrologic budget and conceptual models of subregional ground-water flow and groundwater/surface-water relations were developed specifically for the Georgia subregion RASA and were described by Faye and Mayer (1988). Elements of the conceptual model were based largely on descriptions by Toth (1962, 1963), Freeze (1966), Freeze and Witherspoon (1966, 1967), Hitchon (1969), and Winter (1976). Much of the subregional hydrologic budget was based on data listed by Thomson and Carter (1955).

The results of previous RASA model studies also were incorporated into the calibration of the subregional, digital flow model. These studies, described by Maslia and Hayes (1988) and Krause and Randolph (1989), refer to the Floridan aquifer system, which overlies the aquifers of interest to this study throughout most of the Georgia subregion. Similarly, the Georgia subregion digital flow model was required to interface with neighboring subregional RASA studies, as well as the regional RASA digital model, which encompasses most of the Coastal Plain of the Southeastern United States. Results of adjacent subregional studies in South Carolina were described by Aucott (1988). Corresponding results of regional RASA modeling efforts were described by Barker (1986).
Geologic data utilized in this study included well-site inventories and descriptions, logs and descriptions of borehole cuttings and cores, borehole geophysical logs, outcrop descriptions, paleontologic identifications, and analyses of ground-water quality. Published references included maps, guidebooks, and bulletins. Sources of unpublished data included the files of the U.S. Geological Survey, the Georgia Geologic Survey, and the Geological Surveys of Alabama and South Carolina.

Contributions to knowledge of Southeastern Coastal Plain geology within the study area can be numbered in the hundreds and include papers, theses, bulletins, journal articles, maps, and atlases. To some degree, most of these publications were utilized in the development of the subregional geologic and geohydrologic frameworks. Those publications that were utilized extensively, however, are relatively few and are listed and briefly described below. Emphasis was placed to a large degree on articles that relate geology to aquifers and confining units, that describe geologic or geohydrologic sections, and that describe borehole lithology and paleontology.

Two texts that profoundly contributed to the development of a geohydrologic framework are those of Herrick (1961) and Applin and Applin (1964). Both reports contain detailed descriptions of borehole lithology and paleontology at numerous locations within the Georgia Coastal Plain. These and other chronostratigraphic and lithologic interpretations were combined into a comprehensive description of sediments of Late Cretaceous age in southern Georgia and northern Florida by Applin and Applin (1967). This text contains geologic sections and contour and isopach maps of chronostratigraphic units that were utilized extensively for this study. Maher (1971) also presented cross sections and paleontological data relative to boreholes in the Coastal Plains of eastern and southwestern Georgia and in northern Florida.

In addition, critical paleontological data were published in Applin (1955), McLean (1960), Swain and Brown (1964), Pooser (1965), Herrick and Counts (1968), Hazel (1969), Tschudy and Patterson (1975), Gohn and others (1977), Hazel and others (1977, 1984), Christopher (1982a,b), Colquhoun and others (1982), Valentine (1982, 1984), Gohn, Hazel, and others (1983), Gohn, Houser, and others (1983), Owens and Gohn (1985), Prowell and others (1985), and McFadden and others (1986). In general, these data helped establish provincial stage boundaries and the Cretaceous-Tertiary boundary at boreholes throughout the study area. Beginning with Hazel (1969), many of these studies also indicated that sediments contained within much of the upper Tuscaloosa and upper Atkinson Formations (Applin and Applin, 1967) (pl. 1) were significantly younger than previously considered. A younger age was also suggested for the upper part of the lower Tuscaloosa 
and lower Atkinson Formations of Applin and Applin (1967) (pl. 1). Together these age revisions significantly affected interpretations of geologic and geohydrologic unit continuity north to south across the Georgia subregion.

By far, the greatest number of fossil data utilized in this study were obtained from unpublished data from the files of S.M. Herrick, E.R. Applin, R.A. Christopher, L.E. Edwards, L.M. Bybell, N.O. Frederiksen, J.E. Hazel, and J.A. Miller of the U.S. Geological Survey; W. McGlamery of the Geological Survey of Alabama; K.H. Keahne of the Humble Oil and Refining Co.; E.T. Caldwell of the Humble Oil and Refining Co. and Carpenter Oil Co.; and B.W. McNeely and V.V. Vanstrum of the Shell Oil Co.

The range of selected index fossils was determined by charts and other tabulations published in Pessagno (1967), Charm and others (1969), Owens and others (1970), Pickering (1970), Postuma (1971), Skinner and Steinkraus (1972), Stainforth and others (1975), VanHinte (1976), Gibson (1980b, 1982a,b), Robertson Research (1980), Sohl and Smith (1980), Hazel and Brouwers (1982), and Valentine (1984).

Regional and large-area geological maps used in this study were published by Carlston (1944), Eargle (1955), Siple (1967), Georgia Department of Natural Resources (1976), Buie and others (1979), Huddlestun and Hetrick (1979), and Markewich and Christopher (1982). Corresponding maps of local areas included those published in Alabama by Scott (1961, 1962a), Newton (1965, 1968a,b), and Shamburger (1968). Similar maps in South Carolina by Overstreet and Bell (1965), Smith (1979, 1980), and Nystrum and Willoughby (1982) were also utilized.

Lithostratigraphic cross sections that significantly influenced the geologic interpretations presented in this report were published by Toulmin and LaMoreaux (1963), Gohn and others (1978), Gohn, Bybell, and others (1980), Gohn, Smith, and others (1980), and Prowell and others (1985).

References used to determine the top and nature of rocks at the base of Coastal Plain sediments were those by Christl (1964), Milton and Hurst (1965), Marine and Siple (1974), Marine (1979), Chowns and Williams (1983), and Gohn (1983).

Comprehensive descriptions of faulting and structural effects on Coastal Plain sediments are included in Owen (1963b), Zapp (1965), Prowell and O'Conner (1978), Brown and others (1979), Behrendt and others (1981), Faye and Prowell (1982), Gelbaum and Howell (1982), Miller (1982), Cofer and Manken (1983), McDowell and Houser (1983), Prowell (1983), and Wentworth and Mergner-Keefer (1983).

Other geologic guidebooks, reports, and theses utilized for this study include those written by Cooke
(1943), Owen (1951), Cooke and MacNeil (1952), Siple (1959), Clark (1965), Snipes (1965), Warren and Clark (1965), Zapp and Clark (1965), Sandy and others (1966), Nikravesh (1967), Hester (1968), Scrudato (1969a,b), Herrick (1972), Huddlestun and others (1974), Marsalis and Friddell (1975), Buie (1978), Huddlestun and Hetrick (1978, 1982), Frazier and Taylor (1980), Frederiksen (1980), Gibson (1980a), Gibson and others (1980), Reinhardt (1980, 1982), Oldham (1981), Cofer and Frederiksen (1982), Frazier (1982), Gohn and others (1982), Hack (1982), and Huddlestun (1982).

\section{GEOLOGIC AND GEOHYDROLOGIC FRAMEWORKS}

The correlation of the geologic and geohydrologic units of the Georgia subregion and the relation of geohydrologic units to subregional model layers are summarized in table 1 and plate 1 . The correlation of Georgia subregional framework units with units of adjacent Southeastern Coastal Plain RASA subregions and units of the Floridan RASA are also shown in plate 1. Geohydrologic units defined for the Georgia subregion generally conform to the regional framework described by Renken (1984).

Nomenclature schemes and corresponding regional and subregional geohydrologic unit names were based on criteria established by Laney and Davidson (1986). Geohydrologic nomenclature for the entire Southeastern Coastal Plain RASA is explained by Miller and Renken (1988).

The subsurface distribution and relation of geologic and geohydrologic units are shown in sections drawn parallel to the Chattahoochee, Ocmulgee, and Savannah Rivers in plates 2,3 , and 4 , respectively. The location of geohydrologic section lines and respective borehole locations are shown in figure 1. Site data for boreholes used in geohydrologic sections $A-A^{\prime}, B-B^{\prime}$, and $C-C^{\prime}$ are listed in table 2.

\section{GEOLOGIC FRAMEWORK}

The geologic framework for the Georgia subregion was developed to provide a basis for demonstrating the lateral continuity and stratigraphic relations of subregional aquifers and confining units. Subdivisions of the geologic framework are chronostratigraphic and are based on Gulf Coast provincial stages. Cretaceous units of interest to the digital model analysis range in age from Eaglefordian through Navarroan stages; Tertiary units range in age from Midwayan through Jacksonian stages. Geologic unit boundaries were determined in boreholes by observing the occurrence of index fossils and by using 
TABLE 1.-Relation of geohydrologic nomenclature and model layers used for regional and Georgia subregional Regional Aquifer-System Analysis studies

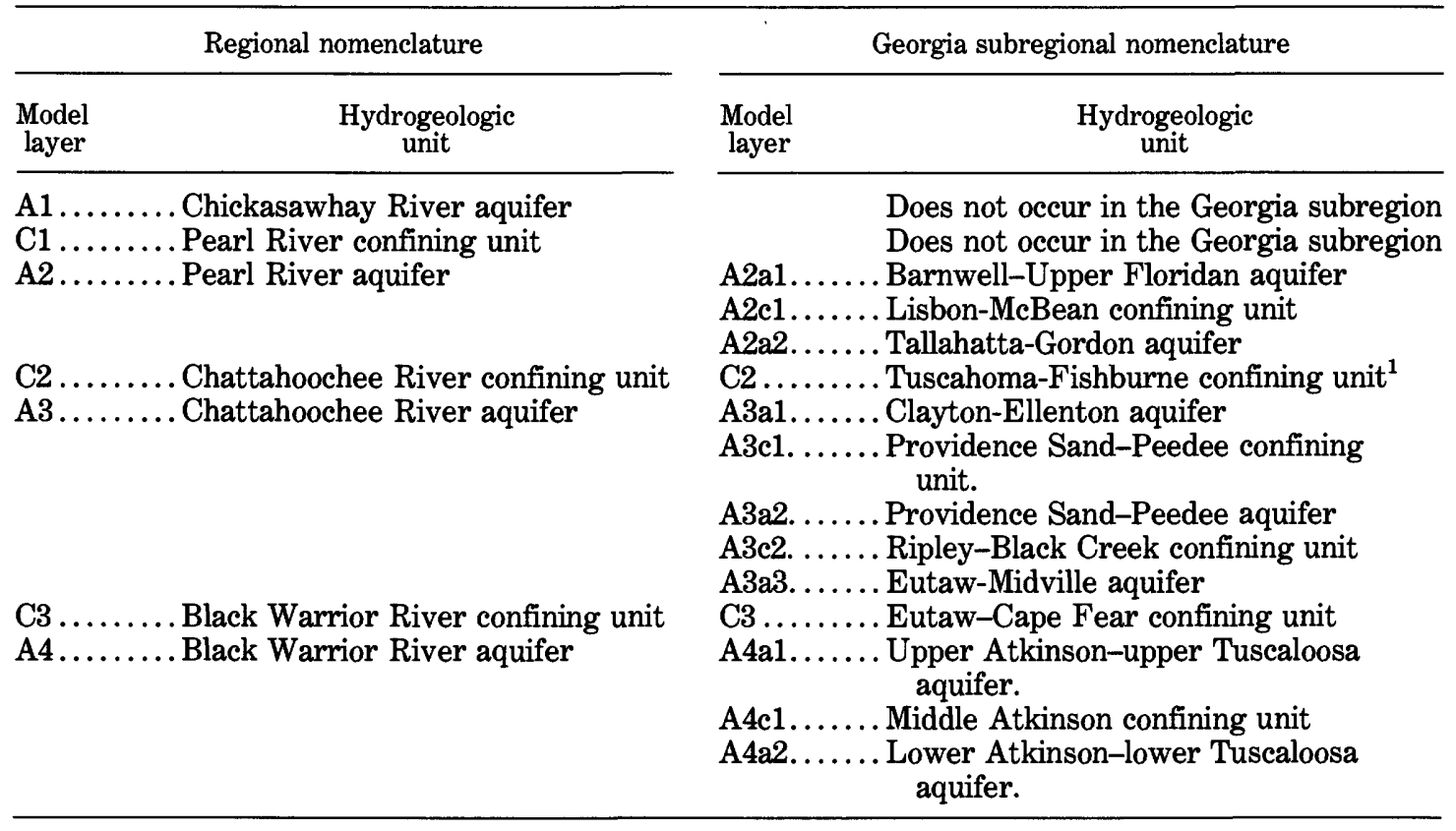

${ }^{1}$ Includes Tuscahoma-Black Mingo aquifer in South Carolina and eastern Georgia.

borehole geophysical logs to characterize a distinct unit lithology or lithologic sequence. Because of the fluviodeltaic nature of Coastal Plain sediments, considerable lithologic variability generally occurs within a single chronostratigraphic unit.

Areas of outcrop of Upper Cretaceous sediments occur along most of the length of the Inner Coastal Plain Margin. In the western part of the subregion, areas of outcrop may extend seaward as much as $50 \mathrm{mi}$. Commonly, the width of individual outcrop areas ranges from about 5 to $15 \mathrm{mi}$. Maps showing areas of outcrop of Upper Cretaceous sediments are included in Carlston (1944), Eargle (1955), Overstreet and Bell (1965), Georgia Department of Natural Resources (1976), Buie and others (1979), Smith (1979, 1980), Markewich and Christopher (1982), and Nystrum and Willoughby (1982).

The subregional lithostratigraphy of Upper Cretaceous sediments is characterized by areally extensive layers of sand and clayey sand alternating vertically with extensive beds of clay, marl, and shale. Where units occur in outcrop in updip parts of the subregion, deposits or beds of clay and marl are lensoidal or otherwise discontinuous. Downgradient near the southern periphery of the subregion, most of the vertical sequence of Upper Cretaceous sediments consists of alternating layers of chalk, shale, clay, marl, sandstone, and, uncommonly, limestone. Areally extensive lithofacies of clay, marl, and shale also occur at or near the tops of Eaglefordian, Austinian, Tayloran, and Navarroan sediments (pls. 2-4). Note that the top of sediments mapped as Eaglefordian age (fig. 5) generally conforms to the top of the "marine shale," which was originally identified as a middle member of the Atkinson and Tuscaloosa Formations (Applin and Applin, 1947, 1964, 1967). This shale is the uppermost stratum in the study area that can be correlated with the Complexiopollis-Atlantopollis zone of Christopher (1982a,b). The actual tops of sediments of Eaglefordian age may occur above the "marine shale" in generally unfossiliferous sediments located for this study in the basal part of sediments of Austinian age.

The maximum thickness of Upper Cretaceous sediments is unknown but probably exceeds $2,000 \mathrm{ft}$ (pl. 2, borehole A1). The maximum thickness of individual units is about $1,500 \mathrm{ft}$, which occurs for Austinian sediments in central-southwest Georgia and adjacent parts of Alabama (pl. 3, borehole G87). Basal Austinian sediments are composed of a thick, areally persistent unit of coarse sand and sandstone thinly interbedded with clay and, infrequently, with shale and mudstone. These sediments were previously related to the upper parts of the Atkinson and Tuscaloosa Formations (Applin and Applin, 1967) and compose most of the upper Atkinson-upper Tuscaloosa aquifer mapped for this study (pls. 1-4). Laterally equivalent sediments compose the upper part of the regional Black Warrior River aquifer (pl. 1) that extends from northeastern South Carolina to northwestern Mississippi (Miller and Renken, 1988). 
TABLE 2.-Index of boreholes used for geohydrologic sections

\begin{tabular}{|c|c|c|c|c|c|c|c|c|}
\hline $\begin{array}{c}\begin{array}{c}\text { Borehole } \\
\text { number } \\
\text { (this report) }\end{array} \\
\end{array}$ & $\begin{array}{l}\text { Operator: } \\
\text { owner name }\end{array}$ & $\begin{array}{c}\text { State } \\
\text { well } \\
\text { number }\end{array}$ & $\begin{array}{c}\text { Other } \\
\text { number }\end{array}$ & $\begin{array}{c}\text { Datum } \\
\text { altitude } \\
\text { (feet) }\end{array}$ & County & $\begin{array}{l}\text { Latitude- } \\
\text { longitude }\end{array}$ & $\begin{array}{c}\text { Total depth } \\
\text { (feet below } \\
\text { datum) }\end{array}$ & $\begin{array}{c}\begin{array}{c}\text { Date } \\
\text { of } \\
\text { completion }\end{array} \\
\end{array}$ \\
\hline \multicolumn{9}{|c|}{$\begin{array}{l}\text { Section } \boldsymbol{A - A ^ { \prime }} \\
\text { Macon County, Alabama, to Jackson County, Florida }\end{array}$} \\
\hline $\mathrm{A} 1 \ldots \ldots \ldots$ & $\begin{array}{l}\text { W.B. Hinton: } \\
\text { O.S. Creel. }\end{array}$ & AP3 & - & 504 & Barbour & $\begin{array}{l}314540 \\
852459\end{array}$ & 8,112 & September 1938 \\
\hline $\mathrm{A} 2 \ldots \ldots \ldots$ & $\begin{array}{l}\text { Williams Develop- } \\
\text { ment Syndicate: } \\
\text { T.R. Grubbs. }\end{array}$ & - & - & 630 & Barbour & $\begin{array}{l}315622 \\
852554\end{array}$ & 3,272 & May 1948 \\
\hline $\mathrm{A} 5 \ldots \ldots \ldots$ & Town of Headland & - & 2 & 373 & Henry & $\begin{array}{l}312037 \\
852020\end{array}$ & 720 & June 1964 \\
\hline A8.......... & $\begin{array}{l}\text { R.W. Williams: } \\
\text { T.H. Whitfield. }\end{array}$ & $\mathrm{I}-4$ & - & 270 & Houston & $\begin{array}{l}311401 \\
852901\end{array}$ & 6,008 & June 1953 \\
\hline$A 9 \ldots \ldots \ldots$ & $\begin{array}{l}\text { Union Producing } \\
\text { Company: } \\
\text { E.P. Kirkland. }\end{array}$ & $\mathrm{Z}-1$ & - & 140 & Houston & $\begin{array}{l}310033 \\
851934\end{array}$ & 8,100 & July 1949 \\
\hline $\mathrm{A} 10 \ldots \ldots$ & $\begin{array}{l}\text { Paul R. Flowers } \\
\text { and Furnie W. } \\
\text { Johnston: } \\
\text { P.E. Mixon. }\end{array}$ & - & - & 280 & Houston & $\begin{array}{l}310713 \\
852418\end{array}$ & 3,201 & November 1966 \\
\hline$A 13 \ldots \ldots$ & Vail Plantation & $\mathrm{U}-4$ & - & 356 & Macon & $\begin{array}{l}321511 \\
853937\end{array}$ & 600 & September 1957 \\
\hline $\mathrm{A} 14 \ldots \ldots$ & $\begin{array}{l}\text { Wadsworth Service } \\
\text { Station. }\end{array}$ & F-5 & - & 544 & Macon & $\begin{array}{l}322802 \\
853443\end{array}$ & 375 & - \\
\hline $\mathrm{A} 15 \ldots \ldots$ & $\begin{array}{l}\text { U.S. Geological } \\
\text { Survey: } \\
\text { Dale County. }\end{array}$ & - & - & 245 & Dale & $\begin{array}{l}312239 \\
853449\end{array}$ & 556 & September 1980 \\
\hline $\mathrm{A} 17 \ldots \ldots$ & $\begin{array}{l}\text { Town of Union } \\
\text { Springs. }\end{array}$ & $\mathrm{L}-3$ & - & 492 & Bullock & $\begin{array}{l}320828 \\
854240\end{array}$ & 1,308 & March 1947 \\
\hline F1......... & $\begin{array}{l}\text { Humble Oil and } \\
\text { Refining Company: } \\
\text { Claude W. Tindel. }\end{array}$ & - & - & 128 & Jackson & $\begin{array}{l}305122 \\
852109\end{array}$ & 9,245 & March 1949 \\
\hline
\end{tabular}

Section $B-B^{\prime}$

Bibb County to Echols County, Georgia

\begin{tabular}{|c|c|c|c|c|c|c|c|c|}
\hline G1 ........ & $\begin{array}{l}\text { Energy Resources } \\
\text { Incorporated: } \\
\text { Georgia Kraft. }\end{array}$ & - & 2 & 442 & Twiggs & $\begin{array}{l}323301 \\
832639\end{array}$ & 1,560 & May 1975 \\
\hline G2 $\ldots \ldots \ldots$ & $\begin{array}{l}\text { J.M. Huber } \\
\text { Company } \\
\text { Plant Well. }\end{array}$ & - & 5 & 265 & Twiggs & $\begin{array}{l}324150 \\
833321\end{array}$ & 615 & December 1976 \\
\hline G15....... & $\begin{array}{l}\text { Strietman } \\
\text { Biscuit Company. }\end{array}$ & GGS357 & - & 370 & Bibb & $\begin{array}{l}324656 \\
833826\end{array}$ & 303 & September 1953 \\
\hline G23....... & $\begin{array}{l}\text { City of } \\
\text { Warner Robins. }\end{array}$ & GGS910 & 5 & 425 & Houston & $\begin{array}{l}323552 \\
833848\end{array}$ & 455 & October 1962 \\
\hline G74....... & $\begin{array}{l}\text { Georgia-Florida } \\
\text { Drilling Company: } \\
\text { H.E. Walton. }\end{array}$ & GGS619 & - & 446 & Dooly & $\begin{array}{l}320345 \\
834004\end{array}$ & 3,748 & April 1960 \\
\hline G77....... & $\begin{array}{l}\text { U.S. Geological } \\
\text { Survey: } \\
\text { Arrowhead \#1. }\end{array}$ & GGS3511 & - & 332 & Pulaski & $\begin{array}{l}322245 \\
832901\end{array}$ & 1,558 & April 1981 \\
\hline G78....... & $\begin{array}{l}\text { Leighton Drilling } \\
\text { Company: } \\
\text { Dana. }\end{array}$ & GGS491 & - & 300 & Pulaski & $\begin{array}{l}321808 \\
832858\end{array}$ & 6,035 & September 1958 \\
\hline
\end{tabular}


TABLE 2.-Index of boreholes used for geohydrologic sections-Continued

\begin{tabular}{|c|c|c|c|c|c|c|c|c|}
\hline $\begin{array}{l}\text { Borehole } \\
\text { number } \\
\text { (this report) }\end{array}$ & $\begin{array}{l}\text { Operator: } \\
\text { owner name }\end{array}$ & $\begin{array}{c}\text { State } \\
\text { well } \\
\text { number }\end{array}$ & $\begin{array}{l}\text { Other } \\
\text { number }\end{array}$ & $\begin{array}{l}\text { Datum } \\
\text { altitude } \\
\text { (feet) }\end{array}$ & County & $\begin{array}{l}\text { Latitude- } \\
\text { longitude }\end{array}$ & $\begin{array}{l}\text { Total depth } \\
\text { (feet below } \\
\text { datum) }\end{array}$ & $\begin{array}{c}\text { Date } \\
\text { of } \\
\text { completion }\end{array}$ \\
\hline \multicolumn{9}{|c|}{$\begin{array}{l}\text { Section } B-B^{\prime} \\
\text { Bibb County to Echols County, Georgia-Continued }\end{array}$} \\
\hline G87....... & $\begin{array}{l}\text { Kerr-McGee } \\
\text { Oil Company: } \\
\text { Cecil Pate. }\end{array}$ & GGS108 & - & 365 & Crisp & $\begin{array}{l}314936 \\
834612\end{array}$ & 5,010 & February 1946 \\
\hline G139...... & $\begin{array}{l}\text { Humble Oil and } \\
\text { Refining Company: } \\
\text { Bennett and Langsdale. }\end{array}$ & GGS189 & - & 181 & Echols & $\begin{array}{l}304529 \\
825436\end{array}$ & 4,185 & May 1949 \\
\hline G143...... & $\begin{array}{l}\text { Wiley P. Ballard, Jr.: } \\
\text { Timber Products } \\
\text { Company. }\end{array}$ & GGS496 & $1 \mathrm{~A}$ & 215 & Clinch & $\begin{array}{l}310906 \\
825150\end{array}$ & 4,232 & February 1956 \\
\hline G147...... & $\begin{array}{l}\text { Sun Oil Company: } \\
\text { Doster-Ladson. }\end{array}$ & GGS107 & - & 222 & Atkinson & $\begin{array}{l}311600 \\
825700\end{array}$ & 4,296 & January 1945 \\
\hline G154...... & $\begin{array}{l}\text { Carpenter Oil } \\
\text { Company: } \\
\text { Nina McLean. }\end{array}$ & GGS445 & $1 \mathrm{~A}$ & 199 & Coffee & $\begin{array}{l}314540 \\
825625\end{array}$ & 1,903 & August 1954 \\
\hline G156...... & $\begin{array}{l}\text { R.O. Leighton } \\
\text { Drilling Company: } \\
\text { T.H. Knight. }\end{array}$ & GGS508 & - & 267 & Coffee & $\begin{array}{l}314107 \\
825319\end{array}$ & 4,151 & May 1956 \\
\hline G157...... & $\begin{array}{l}\text { Chevron Oil } \\
\text { Company: } \\
\text { Oveda Fussell. }\end{array}$ & GGS3127 & - & 295 & Coffee & $\begin{array}{l}312705 \\
830806\end{array}$ & 4,342 & February 1974 \\
\hline \multicolumn{9}{|c|}{$\begin{array}{c}\text { Section } C-C^{\prime} \\
\text { Aiken County to Beaufort County, South Carolina }\end{array}$} \\
\hline $\mathrm{G} 10 \ldots \ldots$ & $\begin{array}{l}\text { Georgia Power Company } \\
\text { Plant Vogtle. }\end{array}$ & - & - & 218 & Burke & $\begin{array}{l}330828 \\
814548\end{array}$ & 928 & June 1972 \\
\hline G29....... & $\begin{array}{l}\text { Continental } \\
\text { Can Company. }\end{array}$ & GGS585 & - & 153 & Richmond & $\begin{array}{l}331941 \\
815712\end{array}$ & 370 & March 1959 \\
\hline G30....... & $\begin{array}{l}\text { Kimberly Clark } \\
\text { Corporation. }\end{array}$ & GGS3446 & - & 287 & Richmond & $\begin{array}{l}331630 \\
815558\end{array}$ & 710 & April 1980 \\
\hline $\mathrm{SC} 1 \ldots \ldots$ & $\begin{array}{l}\text { Savannah River } \\
\text { Plant. }\end{array}$ & $\mathrm{AK}-610$ & $\mathrm{P}-4 \mathrm{~A}$ & 105 & Aiken & $\begin{array}{l}331502 \\
814812\end{array}$ & 697 & September 1962 \\
\hline SC11...... & Town of Bath & AK-438 & - & 240 & Aiken & $\begin{array}{l}332921 \\
815250\end{array}$ & 220 & September 1974 \\
\hline SC16....... & $\begin{array}{l}\text { City of } \\
\text { Allendale. }\end{array}$ & $\mathrm{AL}-23$ & - & 181 & Allendale & $\begin{array}{l}330101 \\
811808\end{array}$ & 882 & February 1967 \\
\hline SC17...... & $\begin{array}{l}\text { Fred Whitaker } \\
\text { Company. }\end{array}$ & AL-19 & - & 162 & Allendale & $\begin{array}{l}330429 \\
812649\end{array}$ & 800 & November 1959 \\
\hline SC26....... & $\begin{array}{l}\text { U.S. Marine Corps } \\
\text { Parris Island. }\end{array}$ & BFT-10 & 2 & 18 & Beaufort & $\begin{array}{l}321947 \\
804227\end{array}$ & 3,450 & November 1940 \\
\hline SC27....... & $\begin{array}{l}\text { Westinghouse } \\
\text { Corporation. }\end{array}$ & HAM-38 & - & 105 & Hampton & $\begin{array}{l}325227 \\
810641\end{array}$ & 1,468 & June 1965 \\
\hline SC28....... & Town of Estill & HAM-92 & - & 110 & Hampton & $\begin{array}{l}324453 \\
811406\end{array}$ & 1,015 & November 1978 \\
\hline SC29...... & $\begin{array}{l}\text { Buckfield } \\
\text { Plantation. }\end{array}$ & HAM-30 & - & 40 & Hampton & $\begin{array}{l}323855 \\
805317\end{array}$ & 1,390 & April 1953 \\
\hline SC30....... & Unknown & HAM-72 & - & 118 & Hampton & $\begin{array}{l}325844 \\
810645\end{array}$ & 551 & December 1976 \\
\hline SC40....... & $\begin{array}{l}\text { U.S. Geological } \\
\text { Survey: } \\
\text { Duncan Farm. }\end{array}$ & $\mathrm{AL}-324$ & - & 203 & Allendale & $\begin{array}{l}330737 \\
813245\end{array}$ & 1,356 & May 1984 \\
\hline SC46....... & $\begin{array}{l}\text { Savannah River } \\
\text { Plant. }\end{array}$ & - & P-5R & 206 & Barnwell & $\begin{array}{l}330848 \\
813627\end{array}$ & 1,270 & November 1962 \\
\hline
\end{tabular}


Water containing dissolved-solids concentrations less than 10,000 milligrams per liter $(\mathrm{mg} / \mathrm{L})$ is considered freshwater for this study and occurs in postEaglefordian, Upper Cretaceous sediments in all but the most seaward parts of the subregion.

Contour maps showing the altitude and the structure at the base of the Coastal Plain sediments and at the top of sediments of Eaglefordian, Navarroan, and Jacksonian age are shown in figures 4-7. The base of Coastal Plain sediments is considered to be the base of rocks of Cretaceous or Jurassic age. The dip at the top of individual units is variable in the vicinity of several major structural features identified as the Apalachicola and the Southeast Georgia embayments and the Peninsular arch (Chowns and Williams, 1983). These structural features are shown schematically in figure 1. Comparison of figures 4-7 indicates the relative continuity of these structural features through time. Depressions at the top of Jacksonian sediments in the central part of the subregion (fig. 7) may be related to the Gulf trough (fig. 1), which is described by Miller (1986) as a narrow series of northeast-trending grabens in central and southwestern Georgia. The Gulf trough is the only structural feature known to extensively influence ground-water flow in the study area (Miller, 1986). A potentiometric map by Johnston and others (1981) indicates that ground-water flow through rocks of Jacksonian age is restricted across the Gulf trough. Flow is probably also restricted through underlying Claibornian rocks in the vicinity of the Gulf trough.

Lower Cretaceous sediments also probably occur within much of the Georgia subregion but have been identified paleontologically only in the western panhandle of Florida (J.A. Miller, U.S. Geological Survey, written commun., 1984). Lower Cretaceous sediments and sediments called Jurassic(?) by Chowns and Williams (1983) occur in the western and south-central parts of the Georgia subregion. The total thickness of these sediments probably exceeds $3,000 \mathrm{ft}$ in southwestern Georgia and adjacent areas of Alabama and panhandle Florida. Lower Cretaceous and older sediments contain saline water throughout most or all of their area of occurrence. Flow within Lower Cretaceous and older Coastal Plain sediments was not simulated by the subregional digital model.

Tertiary lithostratigraphic units of Midwayan through Jacksonian age are characterized by generally clastic sediments in outcrop that grade progressively to carbonate rocks downgradient. The zone of transition between clastic and carbonate rocks within different chronostratigraphic units is variable within the subregion; however, most Tertiary units consist of limestone, dolomite, and coquina within the seaward half of the Coastal Plain. Tertiary clastic units that are updip generally consist of unconsolidated, frequently calcareous sands that commonly are interbedded with lensoidal deposits of clay, marl, and limestone. Clay units at or near the top of Claibornian sediments and within Sabinian sediments seem to be areally persistent and extensive. Gypsum and anhydrite commonly occur in basal Claibornian carbonate rocks and may also occur locally in Sabinian or Midwayan rocks in areas south and southeast of the Gulf trough. In the south-central and eastern parts of the subregion, a relatively thick unit of sand, sandy limestone, or limestone occurs near the midpart and base of Sabinian sediments. This unit is a major source of ground water to wells in southwestern South Carolina (Tuscahoma-Black Mingo aquifer; pls. 1, 3, 4) but was considered to be of insufficient areal extent for study as a subregional aquifer (table 1, pl. 1).

Dissolved-solids concentrations in water samples from lower Tertiary sediments upgradient of the Gulf trough generally are less than $300 \mathrm{mg} / \mathrm{L}$. Seaward of the Gulf trough, in parts of southwestern Georgia and northern Florida, saline water occurs in basal Claibornian rocks, probably in conjunction with gypsiferous and anhydrous rocks (Miller, 1986) and also may occur in contiguous underlying Sabinian and Midwayan rocks. Saline water also occurs in these rocks and in Jacksonian rocks in coastal Georgia and southwestern coastal South Carolina.

\section{GEOHYDROLOGIC FRAMEWORK}

Each geologic (chronostratigraphic) unit was subdivided into areally extensive lithostratigraphic units based on texture, lithology, and apparent permeability. Lithologies characteristic of permeable sediments, such as sands and clayey sands, were combined into aquifer lithofacies. Aquifer lithofacies within each geologic unit were combined with vertically contiguous aquifer lithofacies from underlying and overlying geologic units and mapped as subregional aquifers. Confining-unit lithofacies were organized similarly and mapped as subregional confining units. Consequently, the subregional geohydrologic units do not correspond everywhere to a single geologic unit or to an entire geologic unit because of lithofacies changes within chronostratigraphic units and because geohydrologic units were assembled across chronostratigraphic boundaries.

The correlation and stratigraphic location of subregional geohydrologic units are shown in plate 1. Aquifer and confining unit names generally are based on paired rock-stratigraphic unit names; most of the names are from formations occurring within the Chattahoochee and Savannah River valleys.

Maps showing contours at the top of the TallahattaGordon aquifer, the Tuscahoma-Fishburne confining 


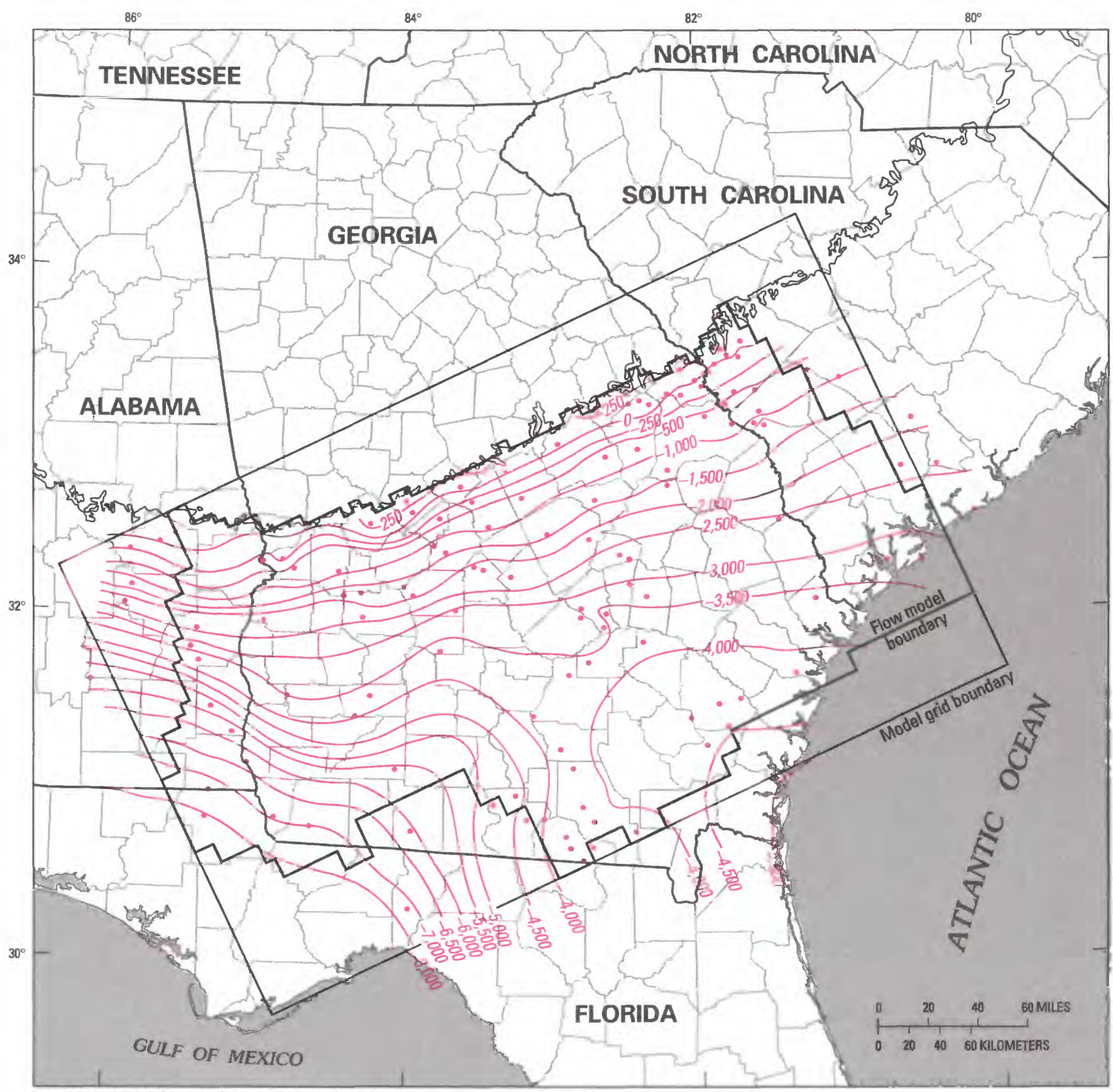

Base reduced from U.S. Geological Survey digital data, 1:2,000,000, 1972

\section{EXPLANATION}

- -250 - Structure contour-Shows altitude of base of the Coastal Plain sediments. Contour interval, in feet, is variable. Datum is sea level

Shon Inner margin of Coastal Plain sediments

- Control point

FIGURE 4.-Altitude at the base of Coastal Plain sediments. 


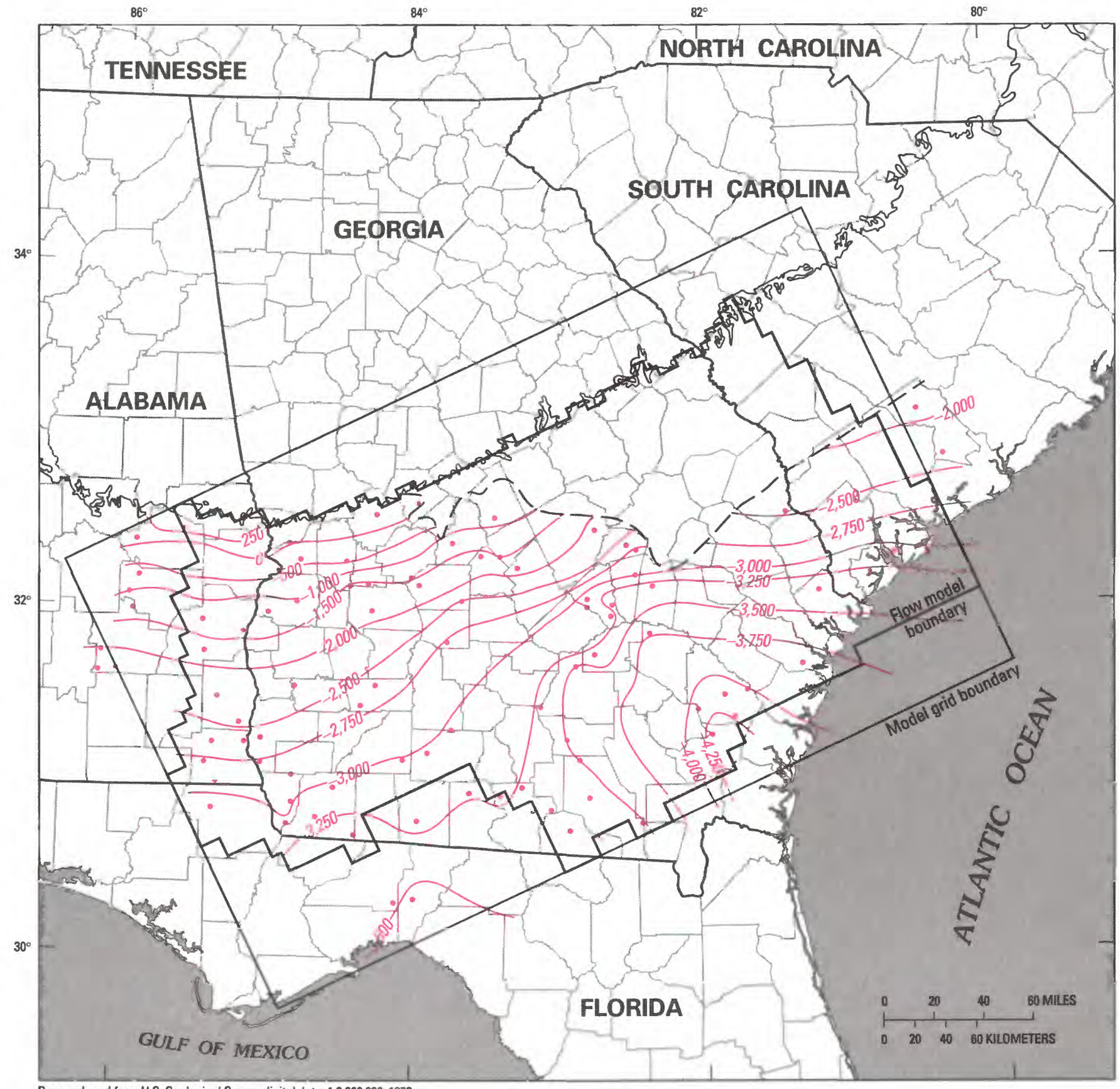

Base reduced from U.S. Geological Survey digital data, 1:2,000,000, 1972

\section{EXPLANATION}

- -500- Structure contour-Shows altitude of top of unit.

Contour interval, in feet, is variable. Datum is sea level

- - Approximate limit of unit occurrence

Shon Inner margin of Coastal Plain sediments

- Control point

Figure 5. - Altitude at the top of Eaglefordian sediments. 


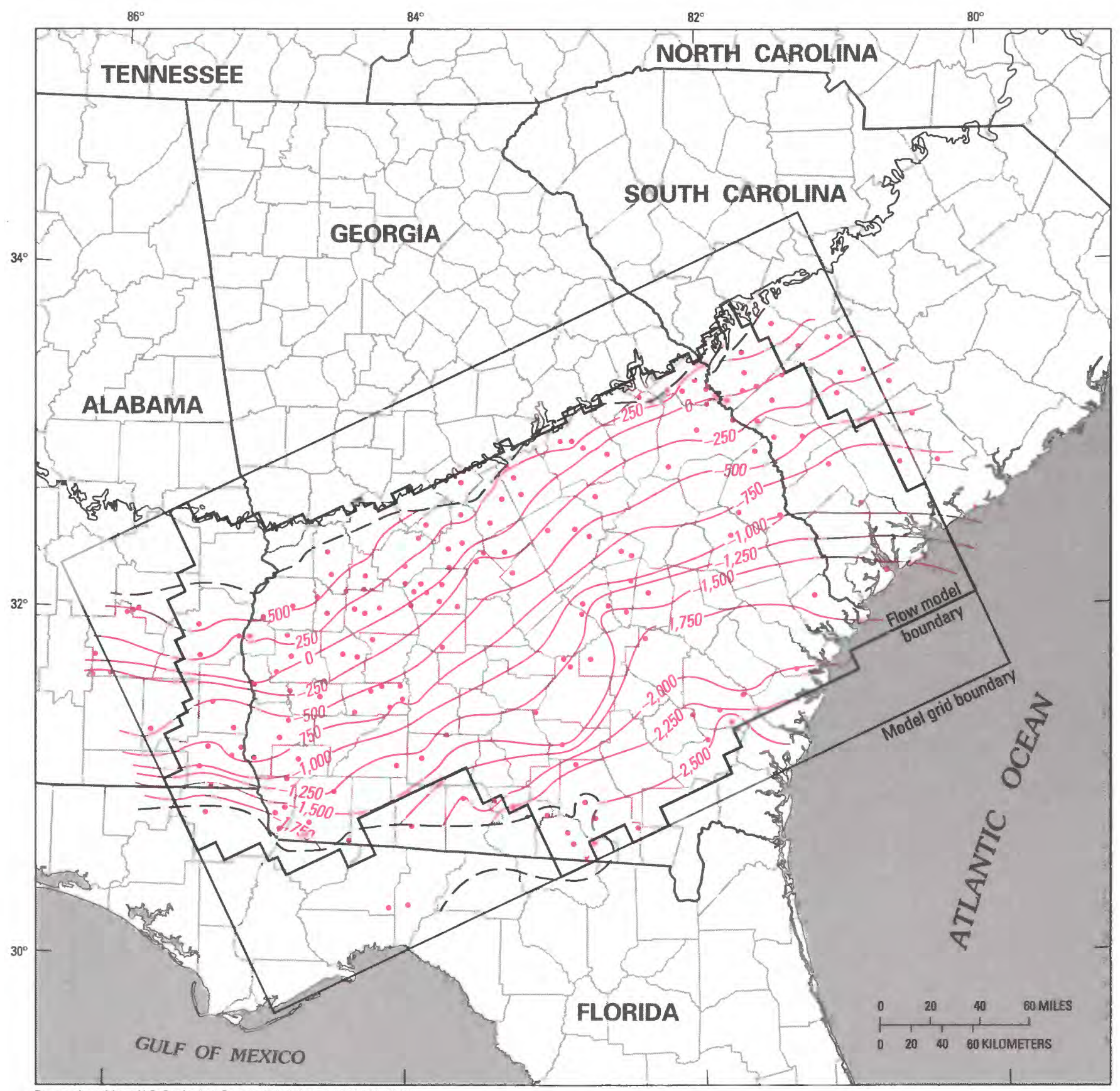

Base reduced from U.S. Geological Survey digital data, 1:2,000,000, 1972

EXPLANATION

- -500- Structure contour-Shows altitude of top of unit.

Contour interval, in feet, is variable. Datum is sea level

- Approximate limit of unit occurrence

Shon Inner margin of Coastal Plain sediments

- Control point

FIGURE 6. - Altitude at the top of Navarroan sediments. 


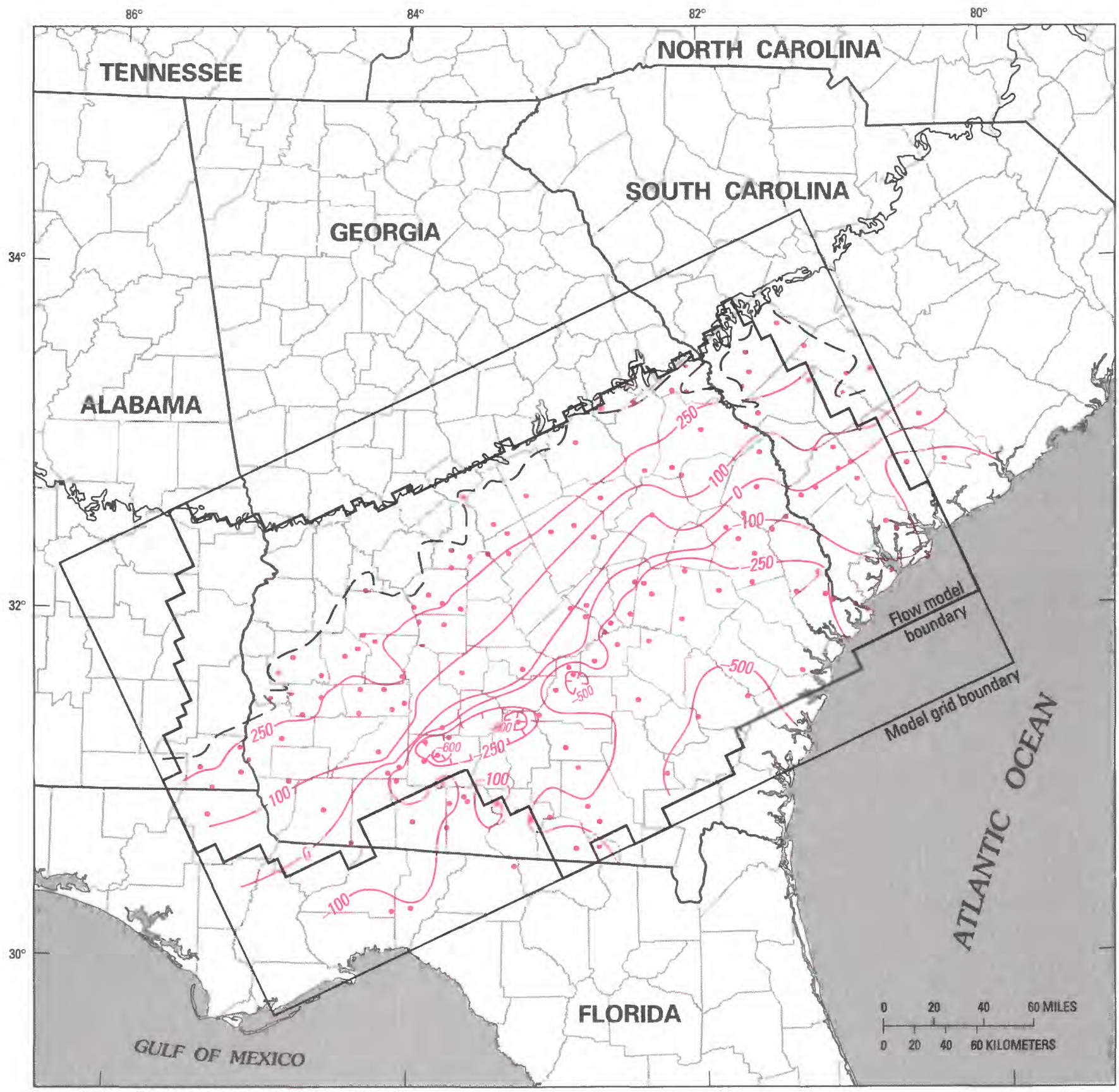

Base reduced from U.S. Geological Survey digital data, 1:2,000,000, 1972

\section{EXPLANATION}

- -500- Structure contour-Shows altitude of top of unit. Hachures indicate depression. Contour interval, in feet, is variable. Datum is sea level

\section{- Approximate limit of unit occurrence \\ SWun Inner margin of Coastal Plain sediments \\ - Control point}

Figure 7.-Altitude at the top of Jacksonian sediments. 
unit, the upper Atkinson-upper Tuscaloosa aquifer, and the middle Atkinson confining unit are shown in figures 8-11. The top of the middle Atkinson confining unit is the base of the freshwater flow system for most of the Georgia subregion. Much of the top of this surface corresponds to the top of the Eaglefordian sediments shown in figure 5. The upper Atkinson-upper Tuscaloosa aquifer (fig. 10) is the basal and the most areally extensive subregional aquifer. The line of $10,000 \mathrm{mg} / \mathrm{L}$ total dissolved-solids concentration shown in figure 10 generally corresponds to the seaward boundary of the subregional flow model. The Tuscahoma-Fishburne confining unit is the most areally extensive and persistent of the Tertiary confining units of the Georgia subregion and underlies the Floridan aquifer system in much of the south-central and southeastern parts of the study area (pls. 1-4). Lithologically equivalent units also extend laterally beyond the boundaries of the Georgia subregion into South Carolina and Alabama (pl. 1) (Miller and Renken, 1988). The Tallahatta-Gordon aquifer is the uppermost layer of the subregional model for which ground-water flow was simulated (fig. 8). The inferred area of very saline ground water shown in figure 8 corresponds to areas of gypsum and anhydrite rocks in the Tallahatta-Gordon and Clayton-Ellenton aquifers. Ground-water flow within these areas was not simulated by the subregional model. The undifferentiated area of the Tallahatta-Gordon aquifer approximately delimits that part of the aquifer where the Lisbon-McBean confining unit is absent and the Tallahatta-Gordon and Barnwell-Upper Floridan aquifers cannot be differentiated on the basis of lithology.

\section{SUBREGIONAL GROUND-WATER FLOW}

\section{CONCEPTUAL MODEL}

Ground-water flow through major aquifers of the Georgia subregion originates in areas of outcrop near and somewhat south of the Inner Coastal Plain Margin (fig. 1). Subregional aquifers are recharged by precipitation within and near outcrop areas, whereas water is lost from the aquifers by evapotranspiration and discharge to nearby rivers and streams. Downgradient and seaward of the outcrop areas, subregional aquifers are confined and are buried progressively deeper in the subsurface (figs. 8, 10). Discharge from downgradient parts of the subregional aquifers primarily occurs as diffuse upward leakage to overlying aquifers.

In the northern part of the subregion, where aquifers are recharged and where discharge to nearby streams occurs relatively quickly, ground-water flow is complex and largely controlled by topography and stream-aquifer relations. A conceptual model of ground-water flow and stream-aquifer relations in this part of the subregion was developed by Faye and Mayer (1988) and is briefly summarized below. The major elements of the conceptual model include flow regimes, hydraulic head, streamaquifer relations, and aquifer recharge and discharge. Many elements of the conceptual model are based on previous investigations of regional ground-water flow described by Toth (1962, 1963), Freeze (1966), and Freeze and Witherspoon $(1966,1967)$.

Flow regimes. - Throughout most of the outcrop areas of the subregional aquifers, total ground-water flow can be conceptually subdivided into local, intermediate, and regional flow regimes. Local flow regimes are characterized by relatively shallow flow paths that extend only from a recharge area to an adjacent area of discharge. Intermediate flow paths include at least one local flow path and are somewhat longer and extend to greater depths than local flow paths. Regional flow paths begin at a major ground-water divide that separates regional drains and generally terminate at a regional drain. A minor component of the regional flow regime is not discharged to regional drains within or near areas of outcrop and flows seaward as downgradient discharge. Ultimately, this downgradient component of regional flow is discharged from the study area as diffuse upward leakage to the Floridan aquifer or subsurface lateral flow to southeastern Alabama and southwestern South Carolina. Accordingly, regional flow paths are the longest and the deepest of any ground-water flow regime. The drainage divide of the Chattahoochee River shown in figure 1 is typical of major ground-water divides in the study area. As previously noted, the Chattahoochee, Flint, Ocmulgee, Oconee, Ogeechee, and Savannah Rivers are the regional drains. The effects of climatic variability and extremes are most pronounced on local flow regimes and least pronounced on regional regimes. Because of the scale and the resolution of the subregional digital flow model, ground-water flow within regional regimes was of primary interest to this study.

Hydraulic head. - The water table within the outcrop and adjacent areas largely is a subdued replica of the land-surface topography. Accordingly, areas of high water-table head generally correspond to highland areas, and areas of low water-table head correspond to lowlands and stream valleys. The influence of the water-table configuration on the hydraulic head at depth is limited largely to the local flow regime, but where major confining units are absent, the influence of the water-table configuration also may extend to the intermediate and regional flow regimes. At major highland areas, such as ground-water divides between regional drains, hydraulic head generally decreases with depth. Hydraulic head in the vicinity of large streams and regional drains increases with depth. 


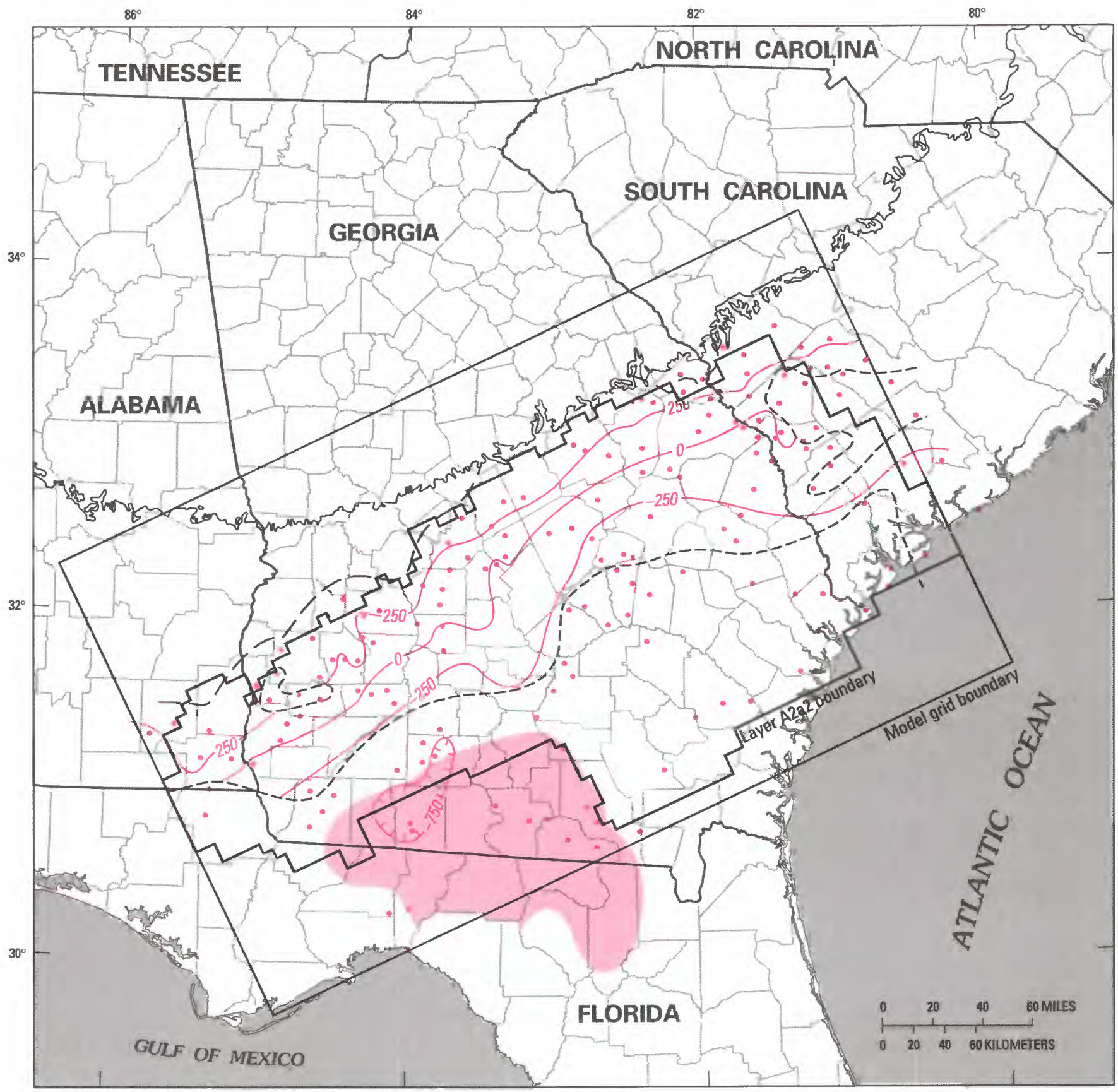

Base reduced from U.S. Geological Survey digital data, 1:2,000,000, 1972

\section{EXPLANATION}

Inferred area of very saline ground waterModified from Miller, 1986

- 250 - Structure contour-Shows altitude of top of unit Hachures indicate depression. Contour interval, in feet, is variable. Datum is sea level
- - Approximate limit of undifferentiated unit

Shorn Inner margin of Coastal Plain sediments

- Control point

- Approximate limit of unit occurrence

Figure 8. - Altitude at the top of the Tallahatta-Gordon aquifer. 


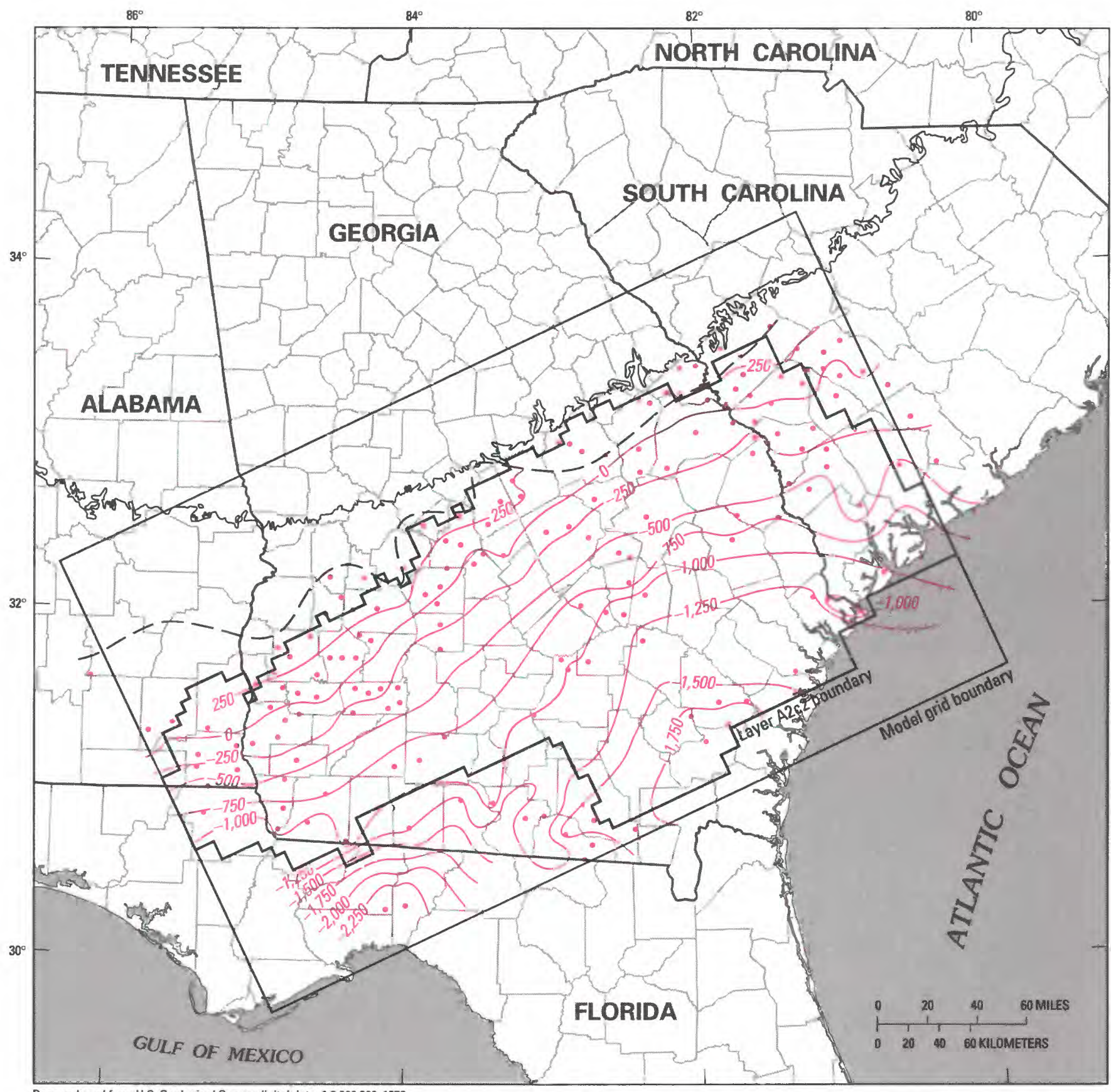

Base reduced from U.S. Geological Survey digital data, 1:2,000,000, 1972

- -500- Structure contour-Shows altitude of top of unit.

Contour interval, in feet, is variable.

Datum is sea level

\section{- Approximate limit of unit occurrence \\ Sfon Inner margin of Coastal Plain sediments \\ - Control point}

FIGURE 9.-Altitude at the top of the Tuscahoma-Fishburne confining unit. 


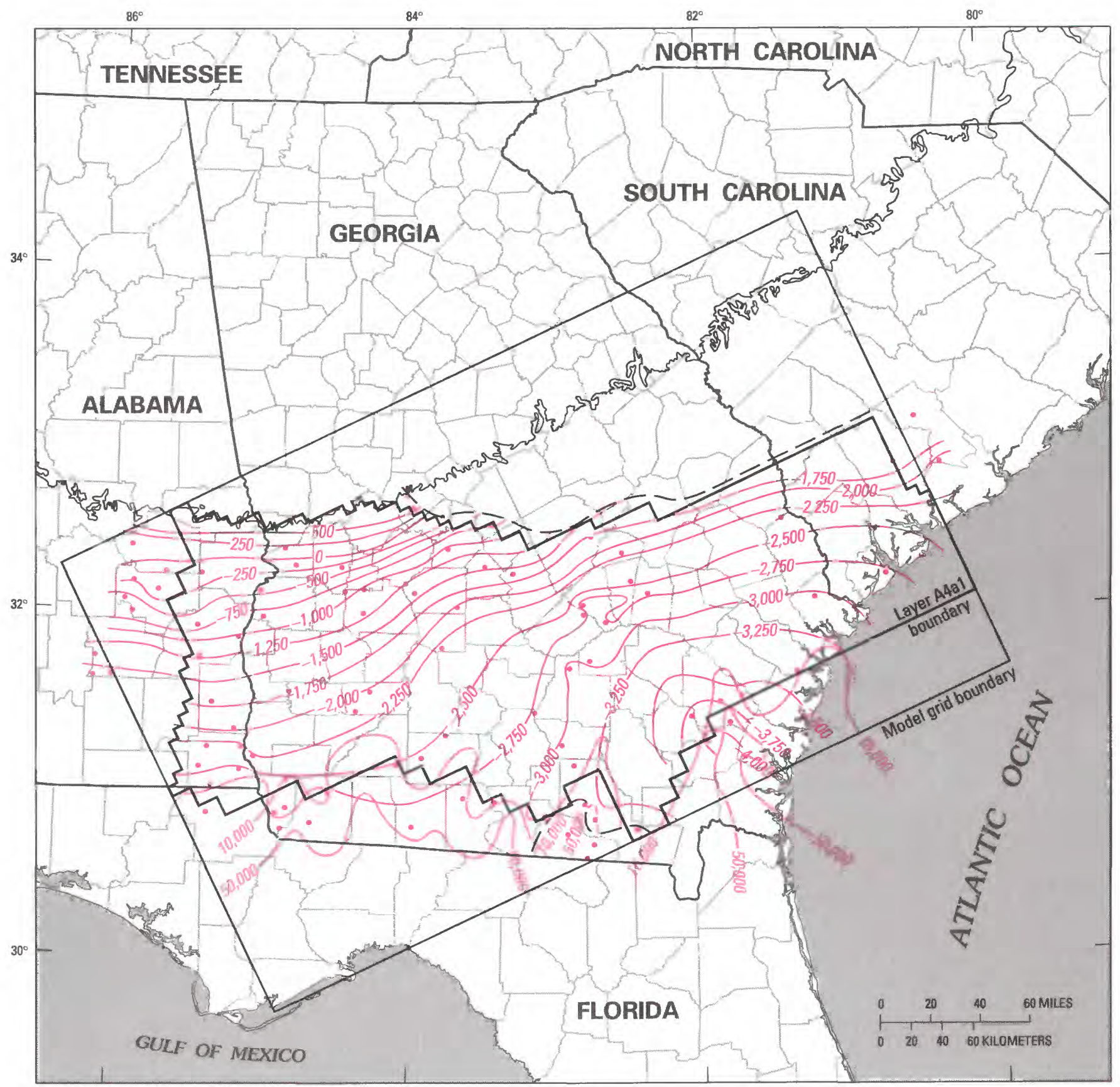

Base reduced from U.S. Geological Survey digital data, 1:2,000,000, 1972
EXPLANATION

$--500-$ Structure contour-Shows altitude of top of unit. Contour interval, in feet, is variable. Datum is sea level

-10000 - Line of equal dissolved-solids concentration-Interval, in milligrams per liter, is variable

- Approximate limit of unit occurrence

Storn Inner margin of Coastal Plain sediments

- Control point

Figure 10.-Altitude at the top of the upper Atkinson-upper Tuscaloosa aquifer. 


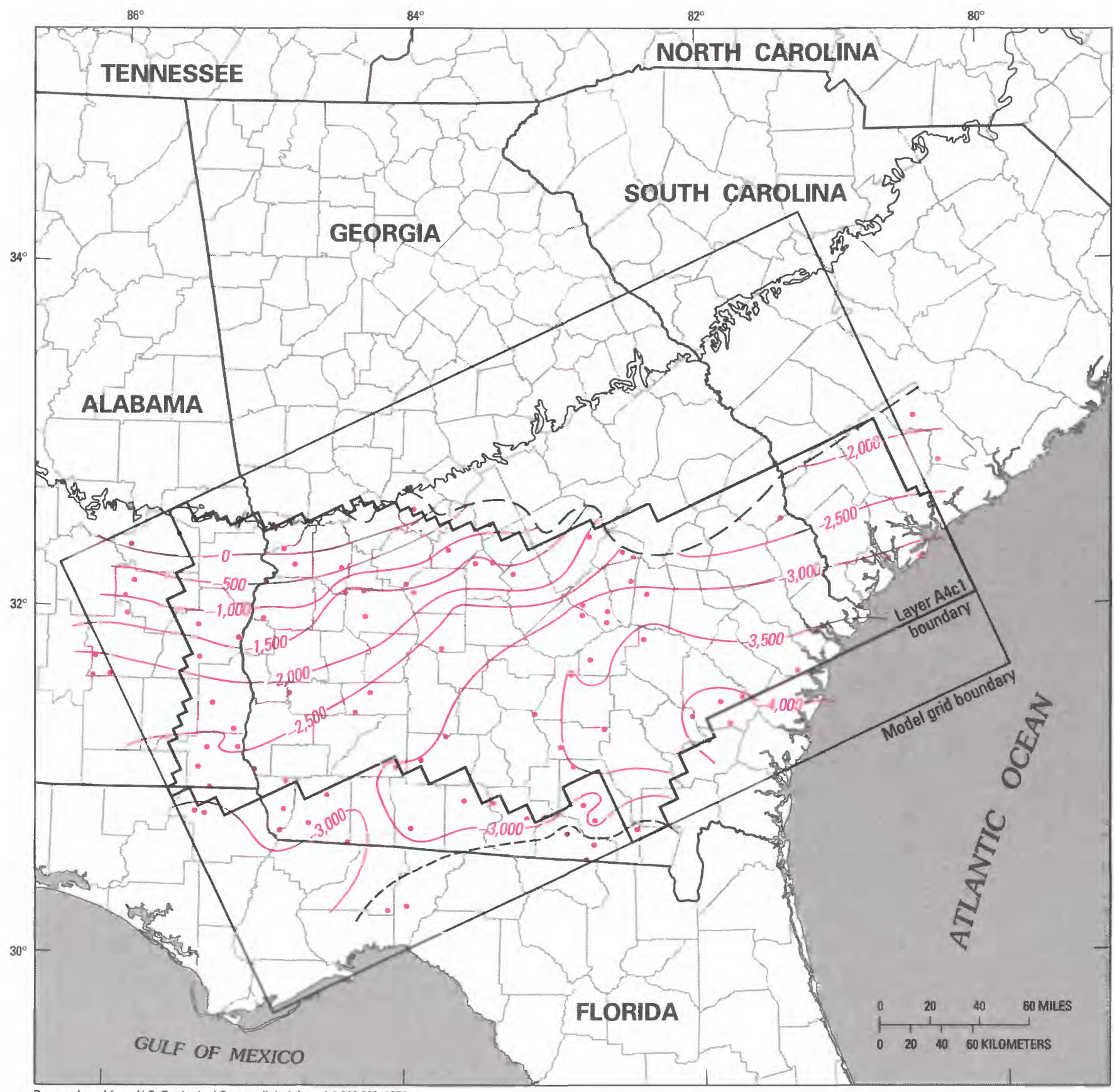

Base reduced from U.S. Geological Survey digital data, 1:2,000,000, 1972

--500 - Structure contour-Shows altitude of top of unit. Contour interval, in feet, is variable. Datum is sea level

- Approximate limit of unit occurrence

-- Approximate limit of undifferentiated unit

Sforn Inner margin of Coastal Plain sediments

- Control point

Figure 11. - Altitude at the top of the middle Atkinson confining unit. 
Stream-aquifer relations. - Streams that are tributary to regional drains receive aquifer discharge from local and from intermediate flow regimes. The lower the tributary stream order, the greater is the relative contribution from local flow regimes. The regional flow regime discharges to the regional drain and to the downstream reaches of the largest tributary streams.

Aquifer recharge and discharge.-The terms "net recharge" and "net discharge" are used in this report to describe the cumulative effect of several processes of recharge to and discharge from the water table, which may occur simultaneously or periodically at a specified site or area. For example, net recharge generally equals the difference between total infiltration to the water table and evapotranspiration from the water table. The distribution of net recharge and net discharge is a function of the water-table configuration, such that net recharge occurs in highland areas and net discharge occurs in lowland areas. Quantities of net recharge and net discharge are distributed variably throughout the flow regimes, and are greatest for local regimes and least for regional regimes. Net recharge to regional flow regimes largely occurs along the major divides between regional drains. Net recharge to intermediate and local flow regimes occurs along the major divides as well as in lower highland areas.

Several elements of the conceptual model were corroborated, in part, by field observations in the Georgia subregion. The influence of topography on hydraulic head is evident on maps by Faye and Prowell (1982) (figs. 12, 13 of this report), which show head data and approximate potentiometric surfaces for the combined Eutaw-Midville, Providence Sand-Peedee, and ClaytonEllenton subregional aquifers (fig. 12) and the Tallahatta-Gordon subregional aquifer (fig. 13) in the vicinity of the Savannah River, near and somewhat south of the Inner Coastal Plain Margin. The potentiometric surface was developed for combined subregional aquifers because elements of the Providence Sand-Peedee and Ripley-Black Creek confining units (pl. 1) are absent from most of the area shown in figure 12. In addition, water-level data included in Christl (1964), as well as unpublished field data, indicate that vertical flow components within the combined aquifers are minimal, except near large streams and the Savannah River. A large number of data were used to construct each map, which includes the areas of outcrop as well as downgradient areas where aquifer sediments are deeply buried. Although the combined aquifers and the TallahattaGordon aquifer are separated by thick, areally extensive layers of laminated clay and mudstone of the TuscahomaFishburne confining unit (pl. 1), the head distribution within each aquifer is shown to be uniformly similar, and generally symmetrical to the Savannah River, which is a regional drain. Head differences between the combined aquifers and the Tallahatta-Gordon aquifer, however, exceed $100 \mathrm{ft}$ near the Savannah River. The influence of topography on the potentiometric surfaces is shown to be especially pronounced near the Inner Coastal Plain Margin. The difference in hydraulic head between the aquifers noted at the Savannah River and the topographic configuration of the potentiometric surfaces support the flow regime and hydraulic head concepts cited previously.

Increasing head with depth in the vicinity of regional drains was also observed by Stephenson and Veatch (1915) at a well adjacent to the Flint River near Montezuma in southwestern Georgia. At this site, hydraulic head progressively increased from $8 \mathrm{ft}$ above land surface at a depth of $60 \mathrm{ft}$, to $62 \mathrm{ft}$ above land surface at a depth of $500 \mathrm{ft}$. In addition, maps by LaMoreaux (1946), LeGrand and Furcron (1956), and LeGrand (1962) indicated "area(s) of artesian flow" within and somewhat downgradient of outcrop areas and adjacent to reaches of the Flint, Ocmulgee, Oconee, Ogeechee, and Savannah Rivers. Flowing wells were observed to occur frequently within such areas, indicating that head at the base of wells exceeds land surface and, thus, may be decreasing upward in the vicinity of regional drains.

Additional corroboration of the conceptual model was accomplished by duplicating the experiments of Freeze (1966) and Freeze and Witherspoon $(1966,1967)$, which evaluated ground-water flow conditions, in cross section, within areally extensive aquifers. The steady-state calibration of two digital models that simulate crosssectional, predevelopment ground-water flow in the northern part of the subregion was described by Faye and Mayer (1988). The results are described below (fig. 14 , table 3) for the calibration of one cross-sectional model relative to a line of section $\left(D-D^{\prime}\right)$ that extends about $26 \mathrm{mi}$ from the major divide between the Flint and Ocmulgee Rivers in Crawford County, Ga., southeast to the Ocmulgee River in southeasternmost Houston County (fig. 1). Lateral hydraulic conductivity of aquifer units used in the cross-sectional model ranged from about 2.0 to 25.0 feet per day (ft/d). Corresponding conductivities of confining units ranged from 0.2 to $0.6 \mathrm{ft} / \mathrm{d}$. The calibrated vertical anisotropy was 0.005 . Aquifer thicknesses ranged from about 50 to $700 \mathrm{ft}$. Confining-unit thicknesses ranged from about 50 to $150 \mathrm{ft}$. No-flow conditions were imposed at the upstream and downstream boundaries and at the base of the section. Specified heads were imposed along the water-table boundary. Calibration required that simulated heads generally match a limited number of field observations to within 15 $\mathrm{ft}$. Maximum, simulated net recharge at any water-table cell was limited to $20 \mathrm{in} / \mathrm{yr}$, based on data from Stricker 


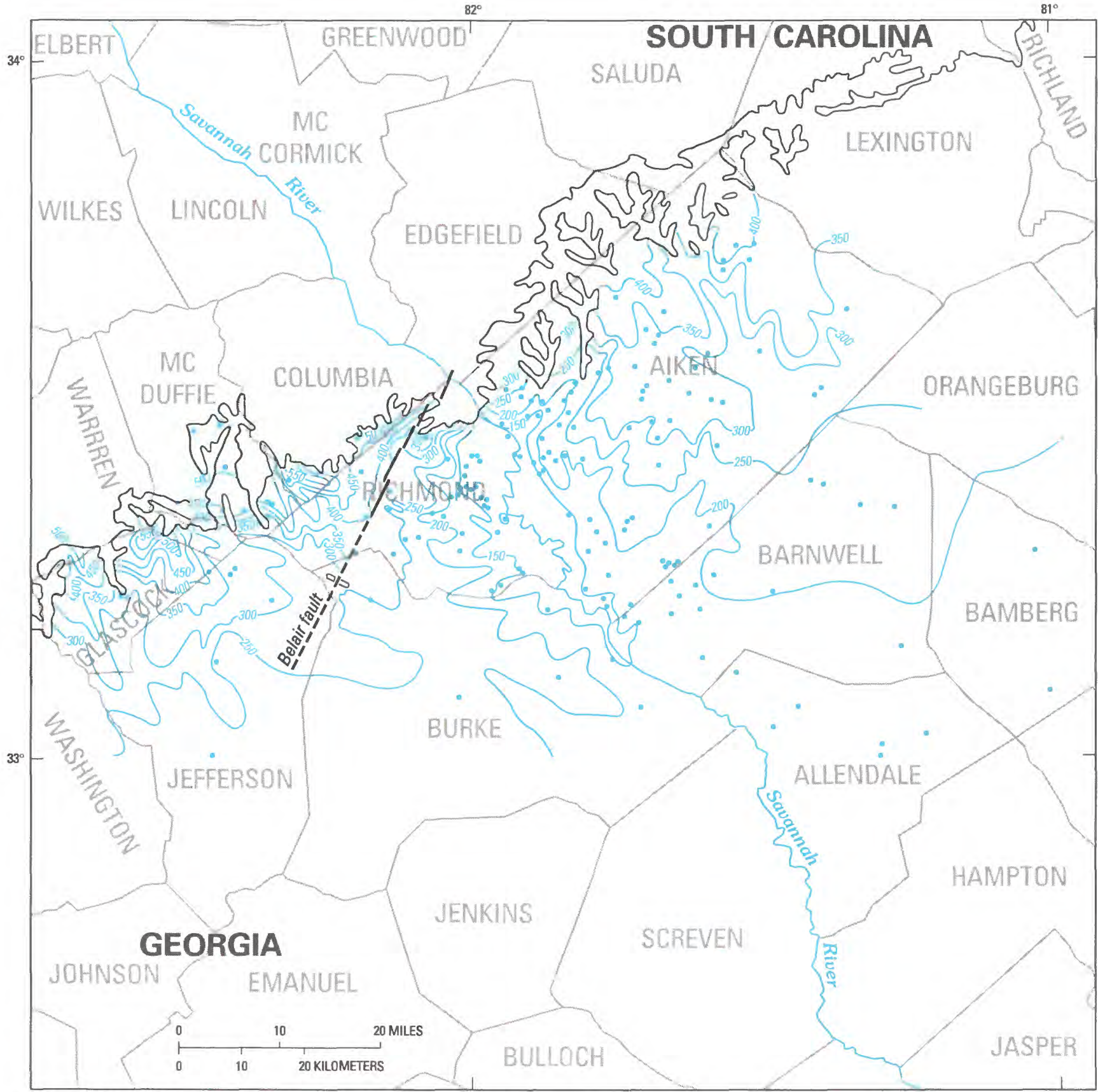

Base modified from U.S. Geological Survey digital data, 1:2,000,000, 1972

\section{EXPLANATION}

$\frac{D}{U}$ - Fault-Dashed where approximately located. U, upthrown side. D, downthrown side

- 290 - Predevelopment potentiometric contour-Shows altitude at which water level would have stood in tightly cased wells. Contour interval 50 feet. Datum is sea level

Inner margin of Coastal Plain sediments

Control well

FIGURE 12. - Estimated potentiometric surface (1940-55) for the combined Clayton-Ellenton, Providence Sand-Peedee, and Eutaw-Midville aquifers near the Inner Coastal Plain Margin and the Savannah River, Georgia and South Carolina (modified from Faye and Prowell, 1982). 


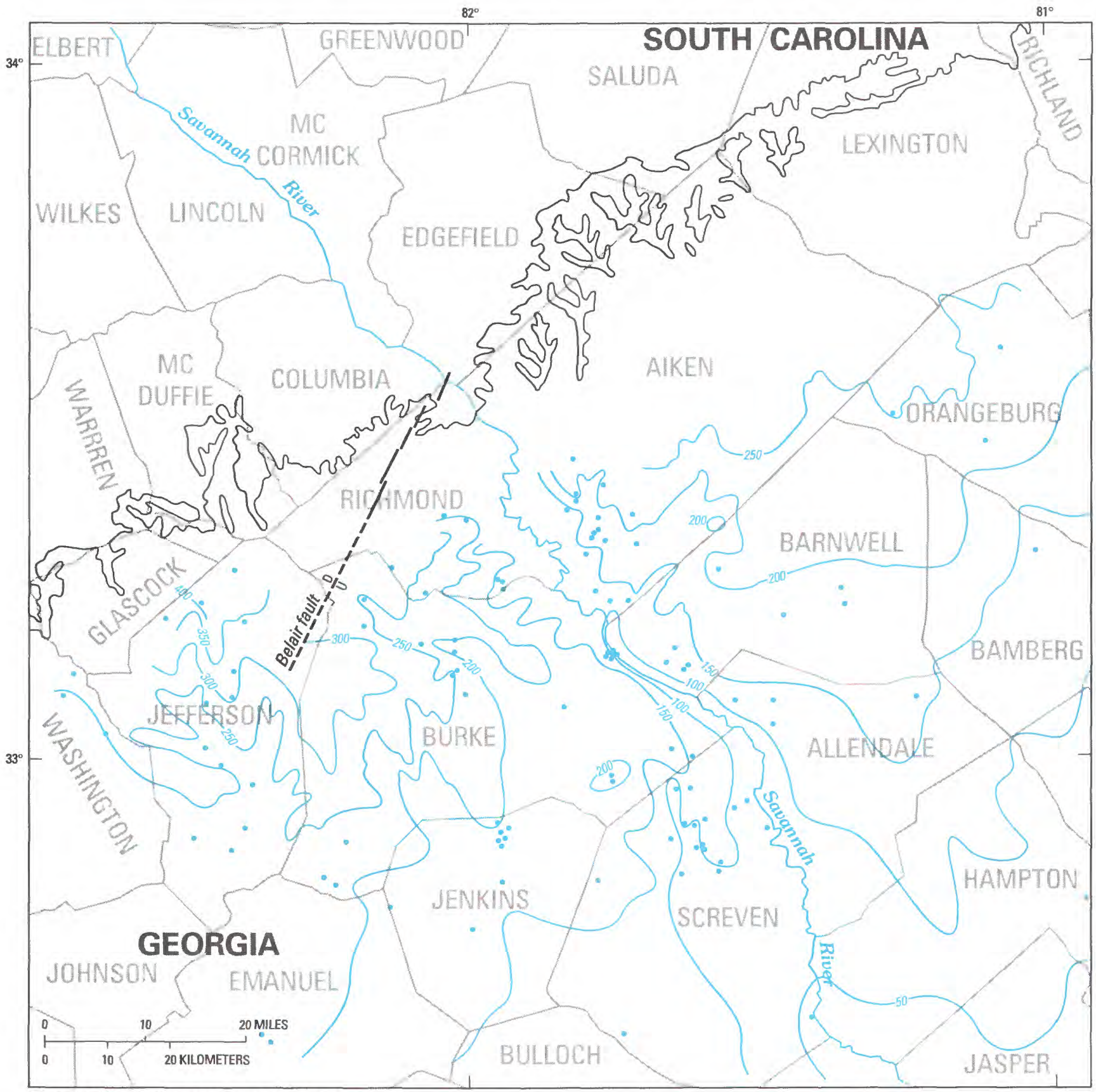

Base modified from U.S. Geological Survey digital data, 1:2,000,000, 1972

\section{EXPLANATION}

$\frac{\text { D }}{\text { U }}-$ Fault-Dashed where approximately located. U, upthrown side. D, downthrown side

- 200 - Predevelopment potentiometric contour-Shows altitude at which water level would have stood in tightly cased wells. Contour interval 50 feet. Datum is sea level

\section{Inner margin of Coastal Plain sediments}

\section{Control well}

FiguRE 13. - Estimated potentiometric surface (1940-55) for the Tallahatta-Gordon aquifer near the Inner Coastal Plain Margin and the Savannah River, Georgia and South Carolina (modifed from Faye and Prowell, 1982). 

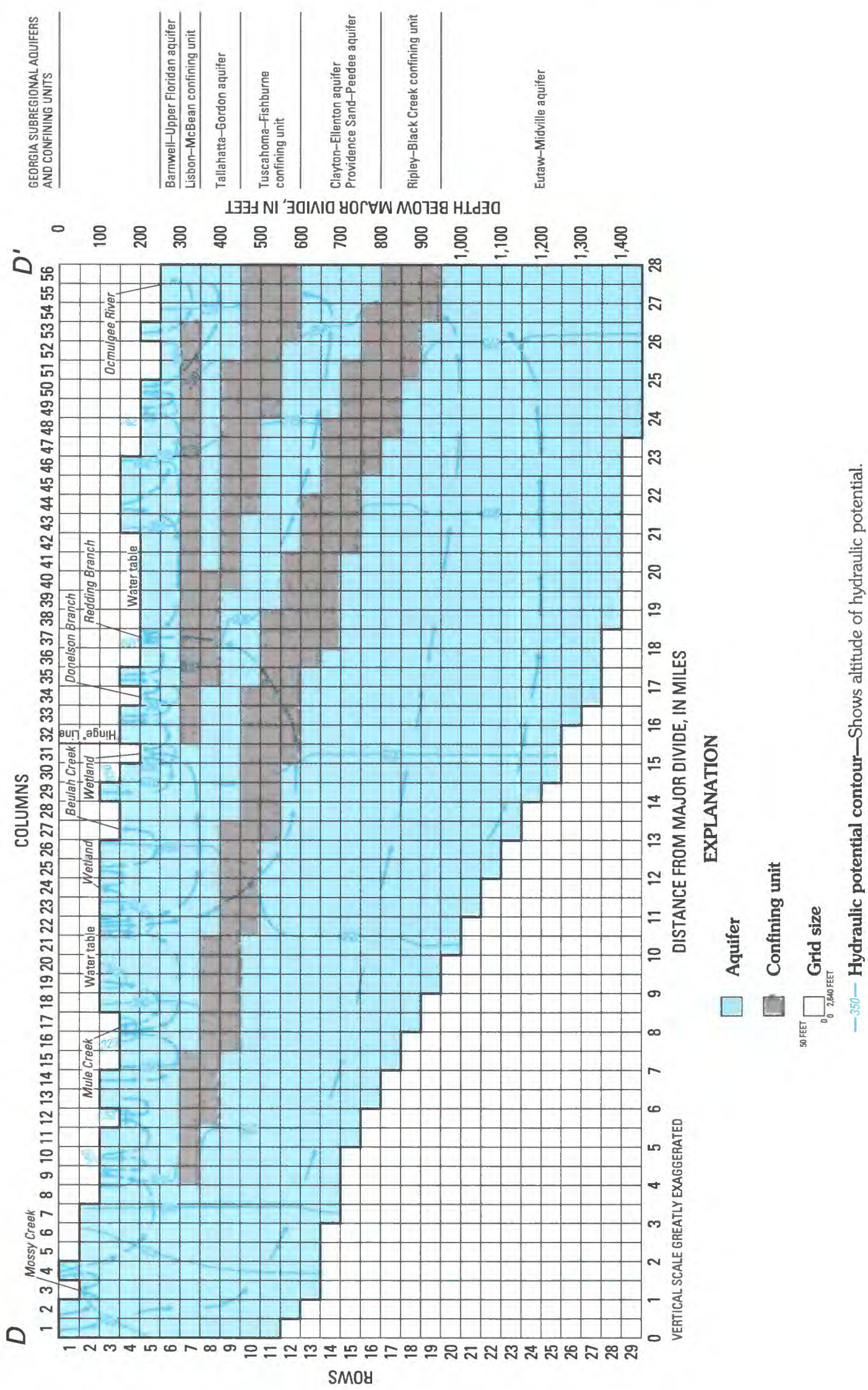

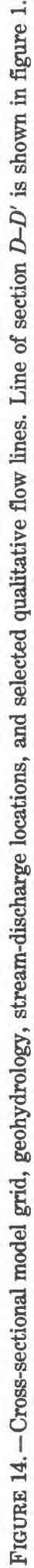


TABLE 3.-Selected predevelopment ground-water net recharge and discharge rates computed by the cross-sectional model

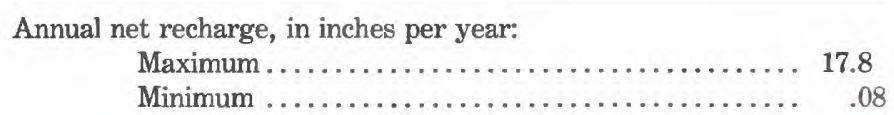

Annual net discharge, in inches per year:

Maximum............................ 20.4

Minimum ...................................

Mean annual net recharge, in inches per year........... 6.1

Mean annual net discharge to regional drain:

Rate, in cubic feet per second per square mile.....

Percent of total net recharge...................

.42

6.5

(1983). Flow lines shown in figure 14 are strictly qualitative and only indicate possible flow paths based on computed hydraulic head. Ground-water pumping along and near the line of section $\left(D-D^{\prime}\right)$ is minor, and simulated flow is considered to approximate predevelopment conditions.

Net rates of predevelopment ground-water recharge and discharge computed by the calibrated cross-sectional model are listed in table 3 . Mean annual net recharge was about 6 in/yr, whereas maximum net recharge was about $18 \mathrm{in} / \mathrm{yr}$. Net discharge to the regional drain (Ocmulgee River) was about 7 percent of the total net recharge. Substantial net discharge also occurred at topographic lows, such as small streams or wetlands. Computed net rates of ground-water recharge and discharge were highly variable along the water-table configuration. A "hinge line" at about mile 16 separated the cross section into general areas of net recharge and net discharge (fig. 14). Hydraulic gradients were shown to be downward near the major drainage divide and upward near the regional drain.

Several elements of the conceptual model and the cross-sectional model analyses apply directly to the calibration of the subregional digital flow model. The variability of net ground-water recharge simulated along the water-table configuration of the cross-sectional model suggests that corresponding net recharge rates applied to the subregional flow model also should be spatially variable. In addition, maximum rates of net recharge to the subregional flow model should be applied at and near the major divides that separate regional drains. Head distributions simulated by the cross-sectional model indicate that large, but directionally opposite hydraulic gradients occur beneath local topographic highs and lows. Such distributions indicate that head data obtained from shallow wells in and near outcrop areas may not represent the vertically averaged head in the aquifer, such heads being below average in stream valleys and above average in highland areas. Shallow well data provided much of the basis for the preliminary potentio- metric maps used in the calibration of the subregional flow model. Accordingly, heads simulated by the subregional model that were higher than observed heads in major stream valleys may be more representative of average field conditions than simulations that closely matched shallow well head data.

\section{HYDROLOGIC BUDGET}

A hydrologic budget of subregional ground-water flow was developed as an aid to calibrating the digital flow model. The computation of budget elements was described in detail by Faye and Mayer (1988) and is summarized below.

The major element of the hydrologic budget was total base flow, which was computed by applying hydrograph separation techniques (Daniel, 1976) to selected regional drain streamflow data. Upstream stations chosen for hydrograph separation were located at or near the Inner Margin of Coastal Plain sediments (fig. 1). The locations of downstream stations were chosen near the seaward limit of outcrop of the subregional aquifers. Annual stream discharge data at each station were chosen to represent relatively low, average, and high streamflow conditions and were separated into components of base flow and surface runoff. Mean annual base flow at each station was then computed as the average base flow of the low, average, and high years. Total mean annual base flow for the Georgia subregion was computed as the gain in stream discharge between upstream and downstream stations and totals 7,880 cubic feet per second $\left(\mathrm{ft}^{3} / \mathrm{s}\right)$ (table 4).

Total base flow (table 4) was divided into local, intermediate, and regional flow components by applying elements of the conceptual model to streamflow data collected at regional drains. Because local flows are affected substantially by climatic variability, local flow to regional drains at the end of extreme droughts was considered to be zero, and remaining streamflows were considered representative only of combined intermediate and regional flows. Additionally, streamflows near the end of a drought were considered to be constant with time and to approximate mean annual discharges from the combined intermediate and regional flow regimes. Drought flow data that approximated these conditions are listed in table 5 . The difference between total mean annual base flow $\left(7,880 \mathrm{ft}^{3} / \mathrm{s}\right.$ ) (table 4) and mean annual discharge from intermediate and regional flow regimes of about $2,730 \mathrm{ft}^{3} / \mathrm{s}$ (table 5) represents the mean annual gain in discharge from local flow regimes between the selected gaging stations. Accordingly, the total discharge from the local flow regime in the Georgia subregion was estimated to be about $5,150 \mathrm{ft}^{3} / \mathrm{s}$.

By definition, discharge from the regional flow regime occurs exclusively to regional drains. Accordingly, 


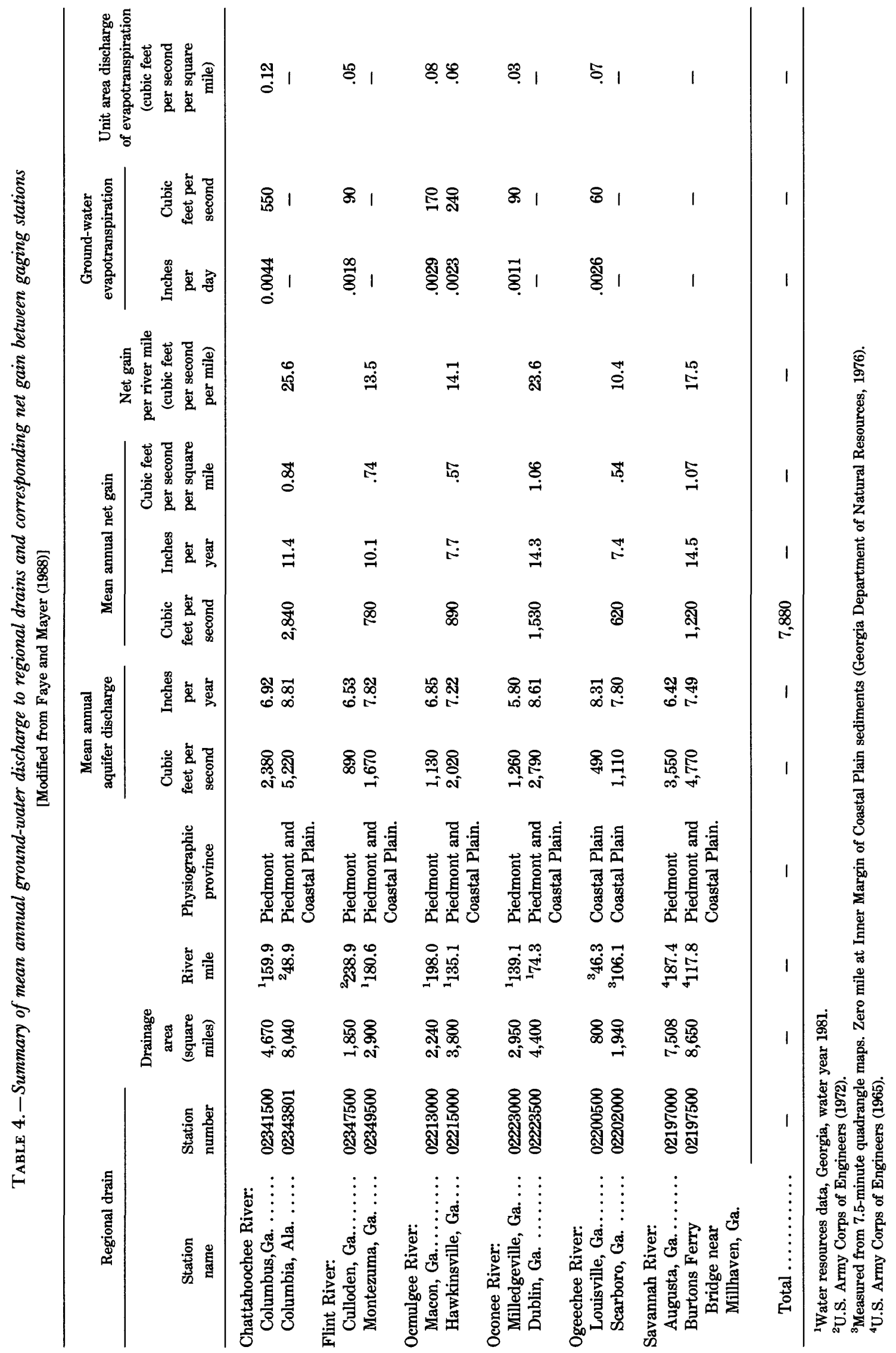


TABLE 5. - Summary of mean annual ground-water discharge to regional drains from combined intermediate and regional flow regimes based on drought streamflows

\begin{tabular}{|c|c|c|c|c|c|c|}
\hline \multicolumn{2}{|l|}{ Regional drain } & \multirow[b]{2}{*}{$\begin{array}{l}\text { Intermediate } \\
\text { drainage area } \\
\text { (square miles) }\end{array}$} & \multirow[b]{2}{*}{$\begin{array}{l}\text { Discharge } \\
\text { (cubic feet } \\
\text { per second) }\end{array}$} & \multirow[b]{2}{*}{ Date } & \multirow{2}{*}{$\begin{array}{l}\text { Net gain in } \\
\text { discharge } \\
\text { (cubic feet } \\
\text { per second) }\end{array}$} & \multirow{2}{*}{$\begin{array}{c}\text { Unit area } \\
\text { discharge } \\
\text { (cubic feet } \\
\text { per second } \\
\text { per square mile) }\end{array}$} \\
\hline $\begin{array}{l}\text { Station } \\
\text { name }\end{array}$ & $\begin{array}{l}\text { Station } \\
\text { number }\end{array}$ & & & & & \\
\hline $\begin{array}{l}\text { Chattahoochee River: } \\
\text { Columbus, Ga........... }\end{array}$ & 02341500 & & ${ }^{1} 640$ & Oct. 5, 1954 & \multirow[b]{2}{*}{237} & \multirow[b]{2}{*}{0.12} \\
\hline Eufaula, Ala............ & 02342960 & & ${ }^{1} 877$ & Oct. 5, 1954 & & \\
\hline Fort Gaines, Ga. ....... & 02343260 & \multirow[b]{2}{*}{470} & ${ }^{2} 1,120$ & Oct. 5,1954 & \multirow[b]{2}{*}{250} & \multirow[b]{2}{*}{.53} \\
\hline Columbia, Ala. ........ & 02343500 & & ${ }^{2} 1,370$ & Oct. 5,1954 & & \\
\hline $\begin{array}{l}\text { Flint River: } \\
\quad \text { Culloden, Ga........... }\end{array}$ & 02347500 & \multirow[b]{2}{*}{1,050} & ${ }^{3} 315$ & Sept. 1981 & \multirow[b]{2}{*}{482} & \multirow[b]{2}{*}{.46} \\
\hline Montezuma, Ga........ & 02349500 & & ${ }^{3} 797$ & Sept. 1981 & & \\
\hline $\begin{array}{l}\text { Ocmulgee River: } \\
\text { Macon, Ga. }\end{array}$ & 02213000 & \multirow[b]{2}{*}{1,560} & ${ }^{3} 165$ & Oct. 1954 & \multirow[b]{2}{*}{282} & \multirow[b]{2}{*}{.18} \\
\hline Hawkinsville, Ga. ...... & 02215000 & & ${ }^{3} 447$ & Oct. 1954 & & \\
\hline $\begin{array}{l}\text { Oconee River: } \\
\text { Milledgeville, Ga........ } \\
\text { Dublin, Ga............. }\end{array}$ & $\begin{array}{l}02223000 \\
02223500\end{array}$ & 1,450 & $\begin{array}{l}{ }^{3} 438 \\
{ }^{3} 933\end{array}$ & $\begin{array}{l}\text { Oct. } 1941 \\
\text { Oct. } 1941\end{array}$ & 495 & .34 \\
\hline $\begin{array}{l}\text { Ogeechee River: } \\
\text { Ga. Highway } 4 \text { near } \\
\text { Louisville, Ga. ....... } \\
\text { Scarboro, Ga............ }\end{array}$ & $\begin{array}{l}02200500 \\
02202000\end{array}$ & 1,140 & $\begin{array}{l}{ }^{1} 59.3 \\
{ }^{2} 143\end{array}$ & $\begin{array}{l}\text { Oct. } 13,1954 \\
\text { Oct. } 13,1954\end{array}$ & 84 & .073 \\
\hline $\begin{array}{l}\text { Savannah River: } \\
\quad \text { Augusta, Ga...... }\end{array}$ & 02197000 & \multirow[t]{2}{*}{1,140} & ${ }^{3} 2,320$ & Oct. 1941 & \multirow[t]{2}{*}{660} & \multirow[t]{2}{*}{.59} \\
\hline $\begin{array}{l}\text { Burtons Ferry Bridge } \\
\text { near Millhaven, Ga... }\end{array}$ & 02197500 & & ${ }^{3} 2,980$ & Oct. 1941 & & \\
\hline Total.............. & & 9,710 & - & - & 2,733 & - \\
\hline
\end{tabular}

${ }^{1}$ Discharge measurement.

${ }^{2}$ Daily mean discharge.

${ }^{3}$ Montlily mean discharge.

regional ground-water flow rates were computed by balancing tributary contributions in a downstream direction with discharge gained between respective regional drain gaging stations over a short time interval. The observed difference in base flow discharge between regional drain gaging stations that could not be accounted for by tributary contributions was attributed to discharge from the regional flow regime. This methodology was applied to selected reaches of regional drains on the Chattahoochee and Flint Rivers in southwestern Georgia and in eastern Alabama, and to the Ogeechee River and Brier Creek in eastern Georgia. Stream discharge data used in the analysis were reported by Thomson and Carter (1955); the data represented tributary and regional drain discharges near the end of the extreme drought of 1954. The computed mean unit area discharge from the regional flow regime was $0.08\left(\mathrm{ft}^{3} / \mathrm{s}\right) / \mathrm{mi}^{2}$, which, when applied to the total of the intermediate drainage areas listed in table $5\left(9,710 \mathrm{mi}^{2}\right)$, provided an estimate of about $780 \mathrm{ft}^{3} / \mathrm{s}$ for discharge from the regional flow regime for the Georgia subregion (table 6).

Riparian evapotranspiration from the water table within the upstream drainages of several regional drain gaging stations was computed in conjunction with hydrograph separations (table 4). The average of the evapo- 
TABLE 6.-Components of the subregional ground-water budget

\begin{tabular}{cccccc}
\hline & \multicolumn{5}{c}{ Mean annual discharge (cubic feet per second) } \\
\cline { 2 - 6 } $\begin{array}{c}\text { Mean annual recharge } \\
\text { (cubic feet } \\
\text { per second) }\end{array}$ & $\begin{array}{c}\text { Discharge from } \\
\text { local flow } \\
\text { regime }\end{array}$ & $\begin{array}{c}\text { Discharge from } \\
\text { intermediate } \\
\text { flow regime }\end{array}$ & $\begin{array}{c}\text { Discharge from } \\
\text { regional flow } \\
\text { regime }\end{array}$ & $\begin{array}{c}\text { Riparian } \\
\text { evapotrans- } \\
\text { piration }\end{array}$ & $\begin{array}{c}\text { Down- } \\
\text { gradient } \\
\text { discharge }\end{array}$ \\
\hline 8,850 & 5,150 & 1,950 & 780 & 660 & 310 \\
\hline
\end{tabular}

transpiration rates $(0.0025$ inches per day (in/d)) was applied to the entire intermediate drainage area $(9,710$ $\mathrm{mi}^{2}$, table 5), to compute a mean annual rate of groundwater evapotranspiration of about $660 \mathrm{ft}^{3} / \mathrm{s}$.

Downgradient discharge is defined for this study as that part of regional flow that is not discharged to streams within or near aquifer outcrop areas and that drains seaward to the southern part of the Coastal Plain. The ultimate fate of downgradient discharge is probably diffuse upward leakage to the Barnwell-Upper Floridan aquifer or lateral subsurface flow to southeastern Alabama and southwestern South Carolina. Callahan (1964, p. 13) estimated that a discharge of about $0.77\left(\mathrm{ft}^{3} / \mathrm{s}\right) / \mathrm{mi}$ moved downgradient across a 400-mi width of the Georgia subregion. The line of discharge shown by Callahan (1964) approximates the seaward extent of outcrops of the subregional aquifers (table 1). The resultant discharge equals approximately $310 \mathrm{ft}^{3} / \mathrm{s}$ and is considered a reasonable estimate of downgradient discharge for this study.

The elements of the hydrologic budget for the Georgia subregion are summarized in table 6. Total mean annual recharge to the subregion is about $9,000 \mathrm{ft}^{3} / \mathrm{s}$. Those budget elements that are most important to this study are downgradient discharge and regional flow regime discharge, which total about $1,100 \mathrm{ft}^{3} / \mathrm{s}$.

\section{SIMULATION OF GROUND-WATER FLOW}

A steady-state model representing predevelopment flow conditions was first used to determine preliminary distributions of aquifer transmissivities, confining-unit leakances, rates of net recharge, and net discharge to streams. After preliminary calibration, the steady-state model was used as a basis for developing a transient model to simulate ground-water pumping and waterlevel declines. The final calibrated model was the result of sequential simulations of steady-state and transient flow conditions accompanied by selective adjustments to net recharge rates and hydraulic characteristic values. A satisfactory final calibration was achieved when the same model data bases for transmissivity, leakance, riverbed conductance, river stage, and net recharge were used for both steady-state and transient simulations and when simulation results conformed to predetermined error criteria. The model data bases used in the final calibrated model are henceforth termed "calibrated" values in this report and are briefly described in the section below called "Hydrologic Input Data." Predevelopment (steady-state) and 1980 potentiometric surfaces and corresponding ground-water budgets computed by the final calibrated model are termed "simulated" in this report.

The nomenclature used to describe model layers is listed in table 1. Also shown are the relations of the Georgia subregion geohydrologic units and model layers to the corresponding regional units of Barker (1986). Each model layer corresponds to a subregional aquifer or confining unit and generally does not encompass the entire study area.

\section{MODEL DESCRIPTION}

The model code used in this study was written by McDonald and Harbaugh (1984) and simulates groundwater flow in three dimensions. The movement of ground water of constant density through a porous medium can be described by the partial differential equation

$$
\frac{\partial}{\partial x}\left(K x x \frac{\partial h}{\partial x}\right)+\frac{\partial}{\partial y}\left(K y y \frac{\partial h}{\partial y}\right)+\frac{\partial}{\partial z}\left(K z z \frac{\partial h}{\partial z}\right)-W=S s \frac{\partial h}{\partial t}
$$

where

$x, y$, and $z$ are Cartesian coordinates aligned along the major axes of hydraulic conductivity $K x x, K y y$, and $K z z$. Hydraulic conductivities are dimensioned in $L T^{-1}$;

$h$ is hydraulic head, in $L$;

$W$ is a volumetric flux per unit volume and represents sources and sinks, in $T^{-1}$;

Ss is the specific storage of the porous material, in $L^{-1}$; and

$L$ and $T$ represent dimensions in length and time, respectively.

Equation 1 describes ground-water flow under nonequilibrium conditions in a saturated heterogeneous and anisotropic porous medium. The model is represented as a three-dimensional matrix of discrete nodes or grid cells; for each cell, a finite-difference equation is formulated that constitutes an approximation of equation 1 . These 
approximations are assembled into a set of simultaneous finite-difference equations that are solved by using the strongly implicit procedure.

For purposes of simulation, subregional aquifers are represented by six model layers; the uppermost layer, A2a1 (Barnwell-Upper Floridan aquifer) (fig. 15), is designated a source-sink layer, and the underlying five layers are defined, herein, as active layers. The lower Atkinson-lower Tuscaloosa aquifer (table 1) is not areally extensive within the Georgia subregion and contains saline water throughout most of its area of occurrence. Accordingly, flow within this aquifer was not modeled.

The horizontal grid of the model consists of 50 rows and 82 columns, and the constant grid cell dimension is 4 mi per side. The grid cell distribution is shown in figure 16 and coincides with that of the larger regional model of Barker (1986). The boundary configurations for each model layer are dissimilar and are based largely on the areal distribution of subregional aquifers and confining units (figs. 16-21). All model layer boundaries, however, are within the 50-row and 82-column model grid configuration (fig. 16).

The model version used in this study does not account for changes in storage or for horizontal flow within confining units. Vertical flow through confining units is simulated and represents leakage from one subregional aquifer to another. Only horizontal flow is simulated within active model layers. Vertical flow components in subregional aquifers are considered to be negligible and, therefore, are ignored.

\section{BOUNDARY AND INITIAL CONDITIONS}

Boundary conditions simulated in this model are no-flow, specified head, and specified flux. Simulated boundary conditions for each active model layer are shown in figures 17-21. No-flow boundaries represent boundaries that naturally inhibit the transverse or vertical flow of ground water. Transverse no-flow boundaries occur at ground-water divides, at interfaces between freshwater and saltwater, and at upgradient limits of aquifer sediments. Ground-water divides result from the distribution of hydraulic heads within the aquifer and generally correspond to topographic divides in the northern part of the subregion (figs. 12, 13). Accordingly, ground-water divides simulated by transverse no-flow boundaries were established along the southwestern and northeastern peripheries of the model that generally correspond to the western drainage divide of the Chattahoochee River and the eastern drainage divide of the Savannah River, respectively. Transverse no-flow boundaries also were simulated at the Inner Margin of Coastal Plain sediments or, where appropriate, at the upgradient extent of aquifer sediments.
A downgradient, transverse no-flow boundary for model layers A3a2, A3a3, and A4a1 (figs. 19-21) was placed in the general vicinity of the $10,000-\mathrm{mg} / \mathrm{L}$ dissolved-solids concentration line shown by Brown and others (1979, units A, C, and D) (fig. 10) and considered in this report to represent saline water. A transverse no-flow, downgradient boundary for model layer A2a2 was also approximately located at the $10,000-\mathrm{mg} / \mathrm{L}$ concentration line in central and southeastern Georgia and in southwestern South Carolina. This line was arbitrarily placed near the modern shorelines of the Atlantic and Gulf Coasts. In central Georgia, the transverse no-flow boundary for model layer A2a2 conforms to the upgradient boundary of the occurrence of rocks containing gypsum and anhydrite at the base of the Upper Floridan aquifer as described by Miller (1986, pl. 29) (fig. 17). Transverse no-flow boundary conditions for model layer A3a1 are similar to those described for layer A2a2, except that specified heads are replaced by a no-flow boundary in the southwestern part of the study area (figs. 17, 18).

Throughout most of the subregion, a vertical no-flow boundary at the model base corresponds to the top of the middle Atkinson confining unit (table 1, fig. 11). In upgradient areas, the base may locally correspond to the top of the Eutaw-Cape Fear confining unit or to the base of Coastal Plain sediments (table 1, fig. 4).

Specified-head boundaries were applied to the entire area of model layer A2a1 (fig. 15), to the northeastern and southwestern peripheries of all model layers downgradient of outcrop areas, and to the westernmost downgradient boundary of model layer A2a2 (fig. 17). Specified-head cells correspond to locations where the designated head is held constant throughout all model computations and act as infinite sources or sinks of ground water for simulated flow. Specified heads at model boundaries were sufficiently removed from pumping centers that transient flow simulations were unaffected, or only minimally affected, by these boundaries.

Specified-flux boundaries were represented in each model layer at recharge cells. Flux rates correspond to average annual net recharge (figs. 17-21).

River cells occur only in the northern part of the Georgia subregion, where streams are well connected hydraulically to subregional aquifers (figs. 17-21). River cells were chosen by layer and by location according to the occurrence of aquifer sediments in outcrop. Because of the coarse grid spacing of the digital model, river cells were located most commonly at regional drains and correspond, from west to east, to upstream Coastal Plain reaches of the Chattahoochee, Flint, Ocmulgee, Oconee, Ogeechee, and Savannah Rivers. Discharge to upstream reaches of Brier Creek, a major tributary to the Savannah River, and to Big Sandy Creek, a tributary to the 


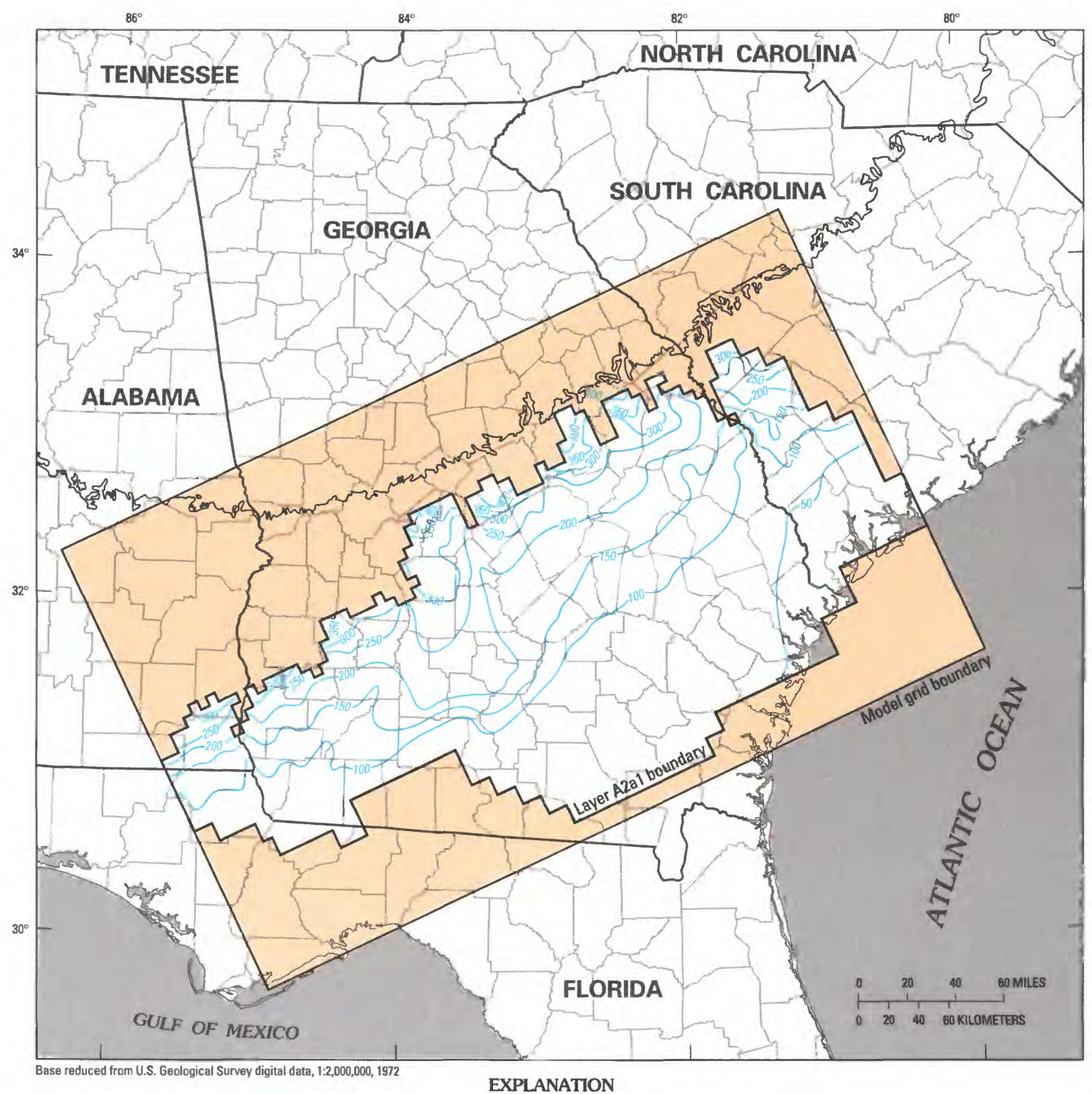

Inactive node

Potentiometric contour-Shows altitude at which water level would have stood in tightly cased wells. Contour interval 50 feet. Datum is sea level

Shorn Inner margin of Coastal Plain sediments

FIGURE 15. - Areal distribution and predevelopment potentiometric surface of specified-head, source-sink model layer A2a1 (Barnwell-Upper Floridan aquifer). 


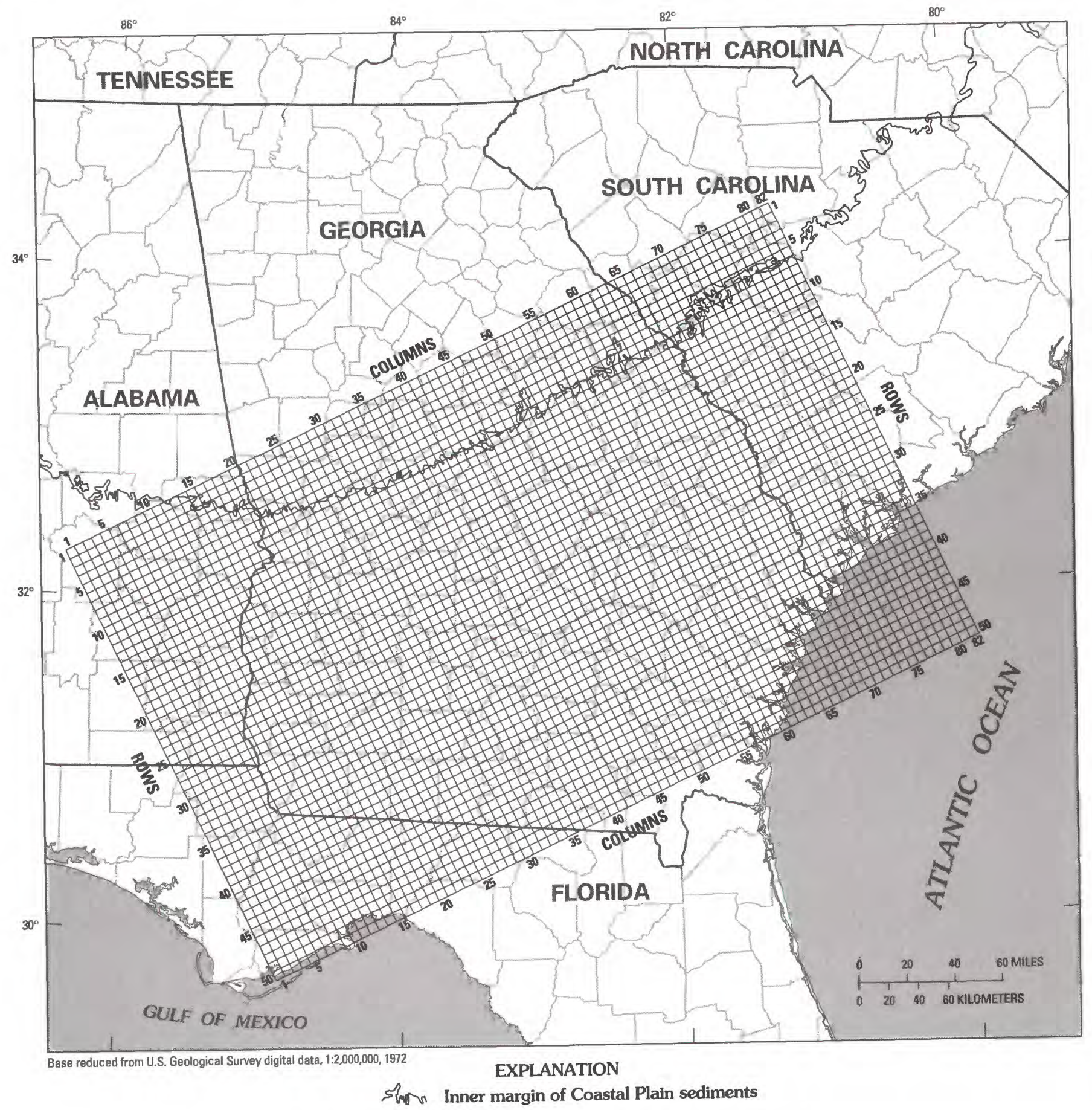

FIGURE 16. - Model grid discretization and grid numbering scheme.

Oconee River, also was simulated. Big Sandy Creek drains an area that is mined extensively for kaolin. Ground-water pumping for the mining industry is large, and pumping centers are distributed throughout the drainage area. Accordingly, Big Sandy Creek presently (1980) is a line sink for ground-water flow along part of its reach and a line source for aquifer recharge along other parts of its reach. Simulation of stream-aquifer interaction along Big Sandy Creek was undertaken to demonstrate the response to pumping of local and intermediate flow regimes near and immediately downgradient of the Inner Margin of Coastal Plain sediments.

Head data used for steady-state calibration were extrapolated from preliminary potentiometric contour 


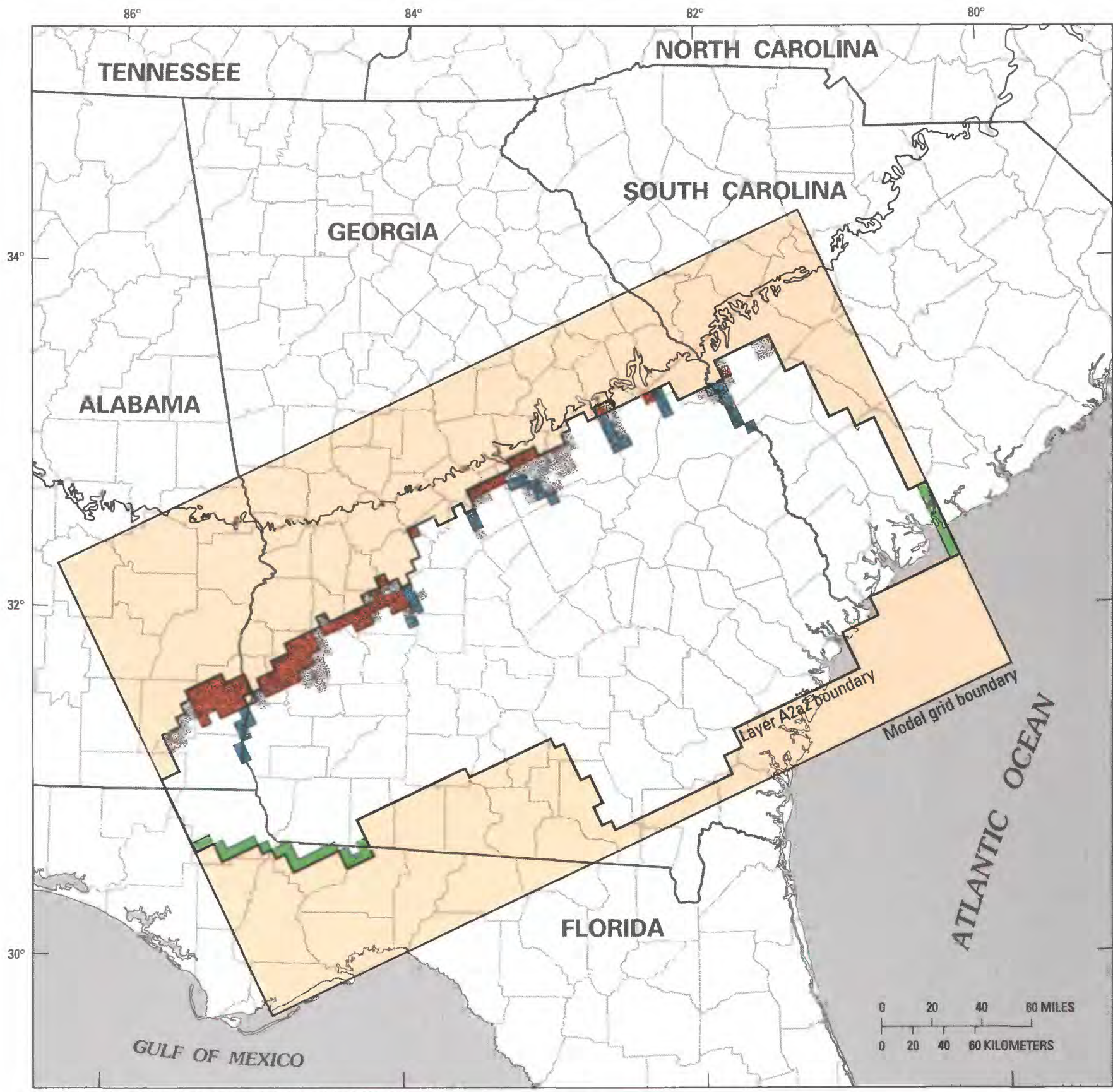

Base reduced from U.S. Geological Survey digital data, 1:2,000,000, 1972

\section{EXPLANATION}

Specified head node

Area where recharge is possible

Recharge node

River node

Inactive node

Sfory Inner margin of Coastal Plain sediments

Figure 17. - Extent of model layer A2a2 (Tallahatta-Gordon aquifer), area where direct recharge is possible, and boundary conditions. 


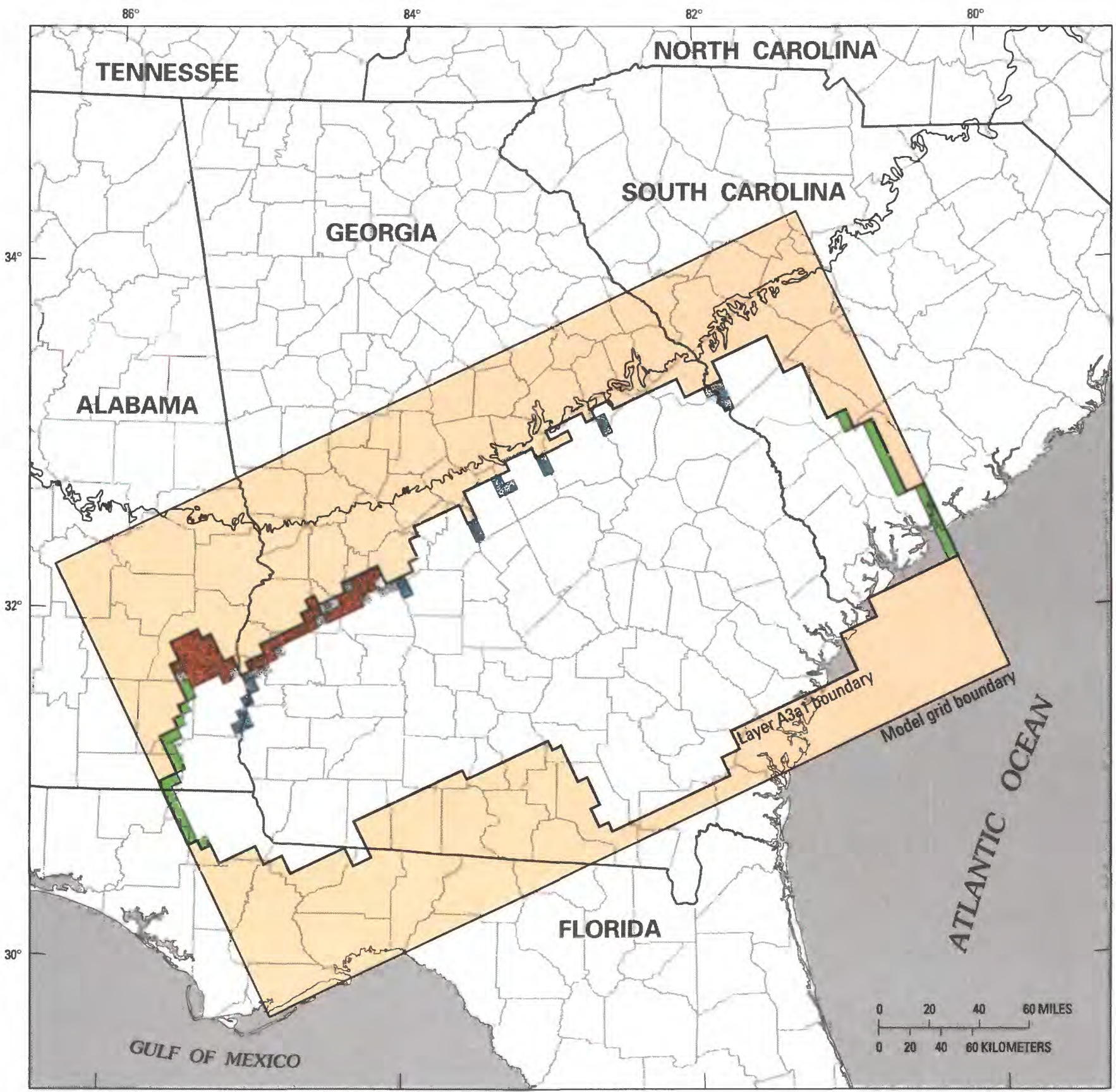

Base reduced from U.S. Geological Survey digital data, 1:2,000,000, 1972

EXPLANATION

Specified head node

Area where recharge is possible

Recharge node

River node

Inactive node

Sfry Inner margin of Coastal Plain sediments

FIGURE 18. - Extent of model layer A3a1 (Clayton-Ellenton aquifer), area where direct recharge is possible, and boundary conditions. 


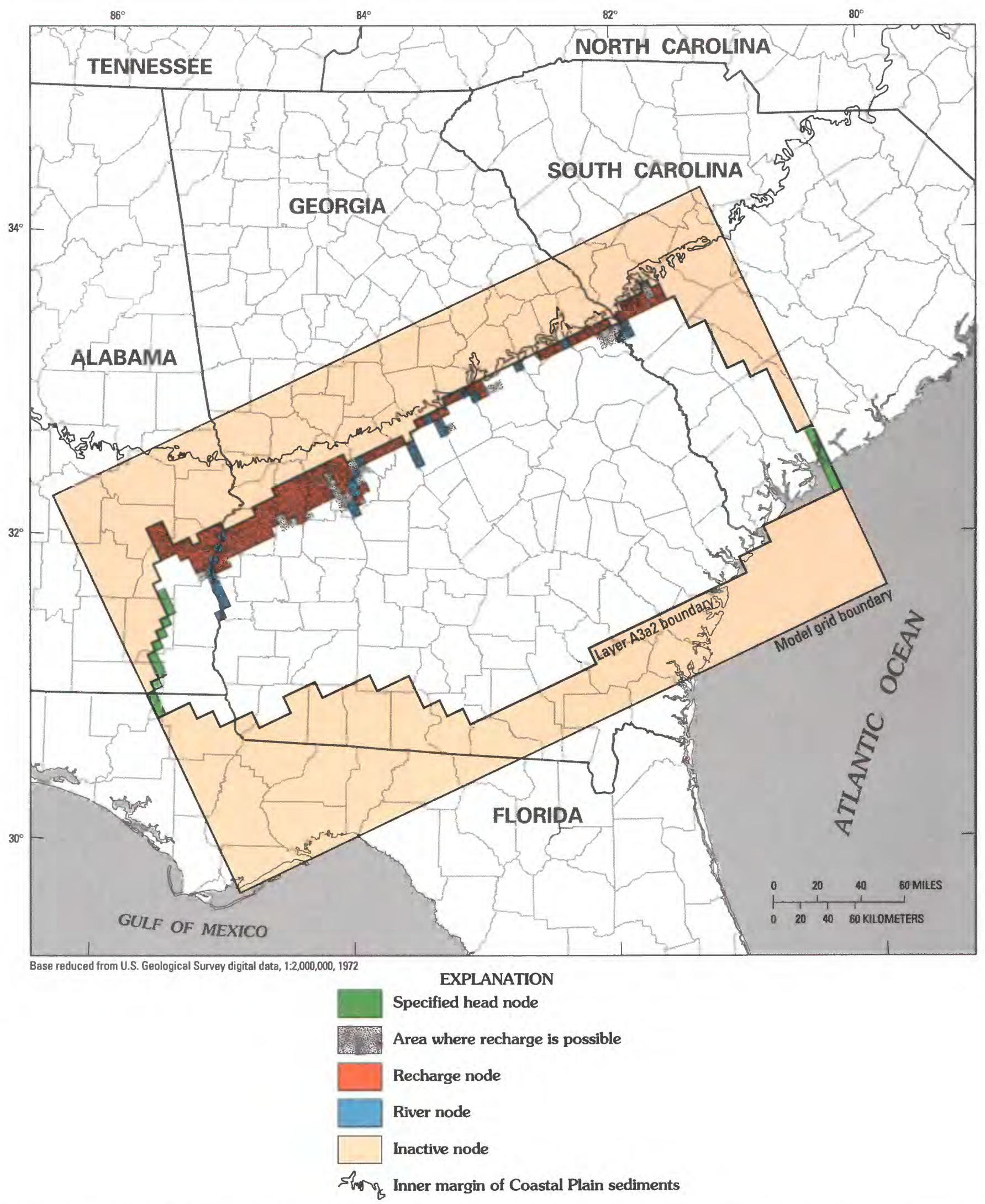

FIGURE 19. - Extent of model layer A3a2 (Providence Sand-Peedee aquifer), area where direct recharge is possible, and boundary conditions. 


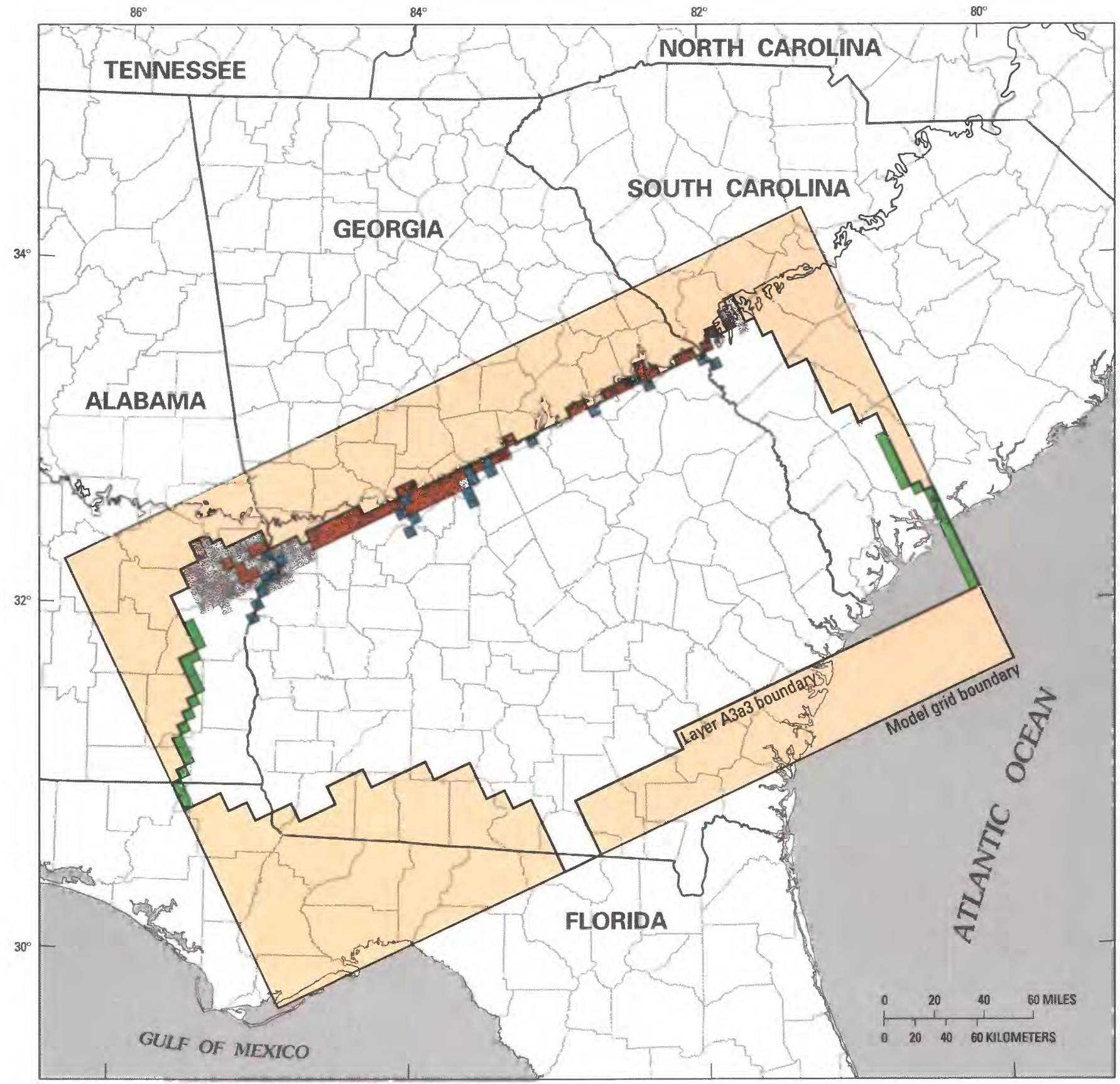

Base reduced from U.S. Geological Survey digital data, 1:2,000,000, 1972

EXPLANATION

Specified head node

Area where recharge is possible

Recharge node

River node

Inactive node

Sfory Inner margin of Coastal Plain sediments

Figure 20. - Extent of model layer A3a3 (Eutaw-Midville aquifer), area where direct recharge is possible, and boundary conditions. 


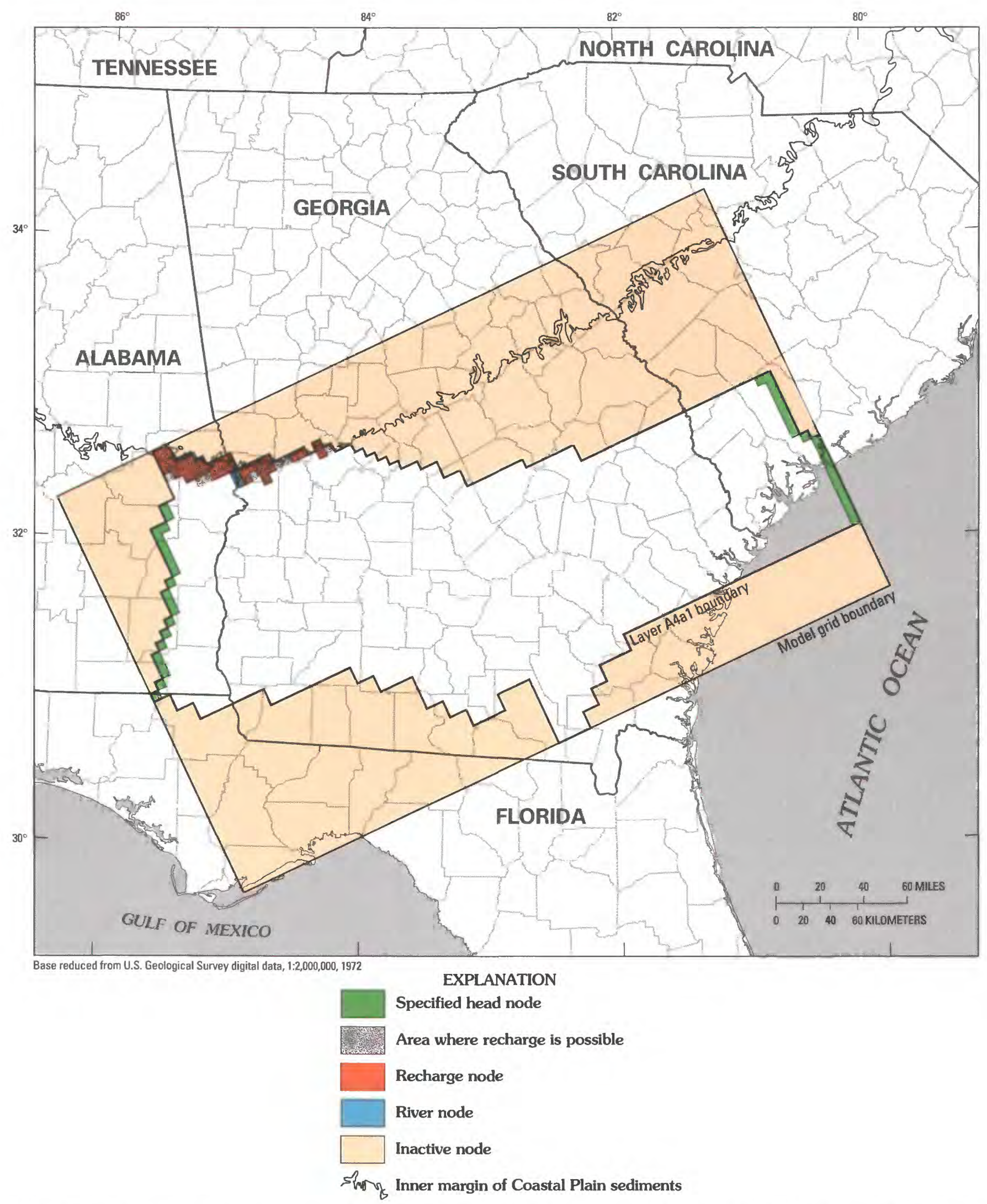

FIGURE 21. - Extent of model layer A4al (upper Atkinson-upper Tuscaloosa aquifer), area where direct recharge is possible, and boundary conditions. 
maps that were considered to represent predevelopment conditions. These maps were based on ground-waterlevel data collected, for the most part, during the period 1939-55, and were obtained for Georgia from Stephenson and Veatch (1915), LaMoreaux (1946), LeGrand and Furcron (1956), and LeGrand (1961). Historical waterlevel data for Alabama were obtained from Carlston (1944). Corresponding data for western South Carolina were obtained from Siple (1946, 1955?).

Initial specified heads assigned to model layer A2a1 (fig. 15) comprised the source-sink layer of the digital model and were based largely on potentiometric maps of the predevelopment surface of the Barnwell Formation by Vincent (1982) and the Ocala Limestone by Warren (1945) and Vorhis (1972). Initial head data used for transient flow simulations were obtained from simulated predevelopment heads that were computed by the steady-state model.

\section{HYDROLOGIC INPUT DATA}

Aquifer and confining-unit properties in the study area are largely unknown. Data describing hydraulic properties of subregional aquifers are few and are limited to the northern part of the subregion (Faye and McFadden, 1986). Observed transmissivities for all subregional aquifers ranged from about 500 to 40,000 feet squared per day $\left(\mathrm{ft}^{2} / \mathrm{d}\right)$, based on analyses of aquifer-test data. Corresponding storativity values ranged from a magnitude of $10^{-4}$ to $10^{-3}$, and averaged about $5 \times 10^{-4}$. The range of subregional aquifer transmissivities used in the calibrated model (figs. 22-26, table 7) corresponds closely to the observed values.

Faye and Mayer (1988) described a trend, from west to east, of increasing aquifer transmissivity in the northern part of the Georgia subregion, based on aquifer diffusivities computed from hydrograph recessions at regional drain gaging stations. Although the diffusivity-based transmissivities represent a composite response from all subregional aquifers within the area draining to a gage, a similar trend for individual subregional aquifers was applied to the development of transmissivity matrices for model layers A2a2, A3a2, and A3a3 (figs. 22, 24, and 25).

Transmissivity values in layer A2a2, southeast of the Gulf trough (fig. 1), were based on previous model studies of the Floridan aquifer system (R.E. Krause, U.S. Geological Survey, written commun., 1984).

Data pertinent to the computation of confining-unit leakances are unavailable for the study area, and leakance values used in the model are strictly the result of model calibration (figs. 27-31, table 8). Calibrated leakance values ranged from magnitude $10^{-8}$ to $10^{-13} / \mathrm{s}$ and generally decreased seaward of the Inner Coastal Plain Margin. Calibrated leakances in the northern part of the study area generally ranged from a magnitude $10^{-9}$ to $10^{-11} / \mathrm{s}$, which agreed favorably with confining-unit leakances computed in cross-sectional models of groundwater flow (fig. 14) in the north-central and northeastern parts of the study area (Faye and Mayer, 1988).

For this study, simulated net recharge to the regional flow regime represents that part of precipitation that infiltrates to the water table of subregional aquifers, subsequent to loss to evapotranspiration. The conceptual model indicates that areal variability of net recharge may be significant and that most net recharge likely occurs along major stream divides and in other highland areas. Accordingly, topography and the distribution of outcrops of aquifer sediments were used to locate recharge cells for each subregional aquifer (figs. 17-21). Net recharge rates applied to the calibrated model ranged from less than 0.5 to about 9 in/yr per model layer (table 9 ) and averaged about $1 \mathrm{in} / \mathrm{yr}$ for the entire subregion. Net recharge rates applied to the model are considered average annual rates for the specified period.

River node stages and bottom altitudes for all regional drains, except the Ogeechee River, were interpolated from river profiles published by the U.S. Army Corps of Engineers (1945a,b, 1949a,b,c,d, 1959, 1965). The stages and bottom altitudes for the Ogeechee River, Big Sandy Creek, and Brier Creek were estimated from topographic maps and from streamflow records. Riverbed conductances applied to river cells were determined during model calibration.

\section{CALIBRATION}

The ground-water flow model for the Georgia subregion was successfully calibrated by applying appropriate elements of the conceptual model and the hydrologic budget to the simulation of hydraulic heads and aquifer discharge. The calibration procedure was iterative. The quality of the calibration was primarily evaluated by comparing simulated heads to observed field heads, and by comparing simulated river discharge to total regional flow regime discharge computed for the hydrologic budget (table 6). Adjustments to initial input parameters during the calibration process involved changes in confining-unit leakance, riverbed conductance, and rates of net recharge. Less substantial changes were made to matrices of transmissivity and storativity.

In general, the location of observed field heads used as a calibration standard did not correspond precisely to the center of grid cells. Rather, for purposes of comparison, the field observations were interpolated to appropriate grid cell centers by using hydraulic gradients determined from preliminary potentiometric maps. In the northern part of the subregion, where potentiometric gradients are relatively large, differences between observed and 


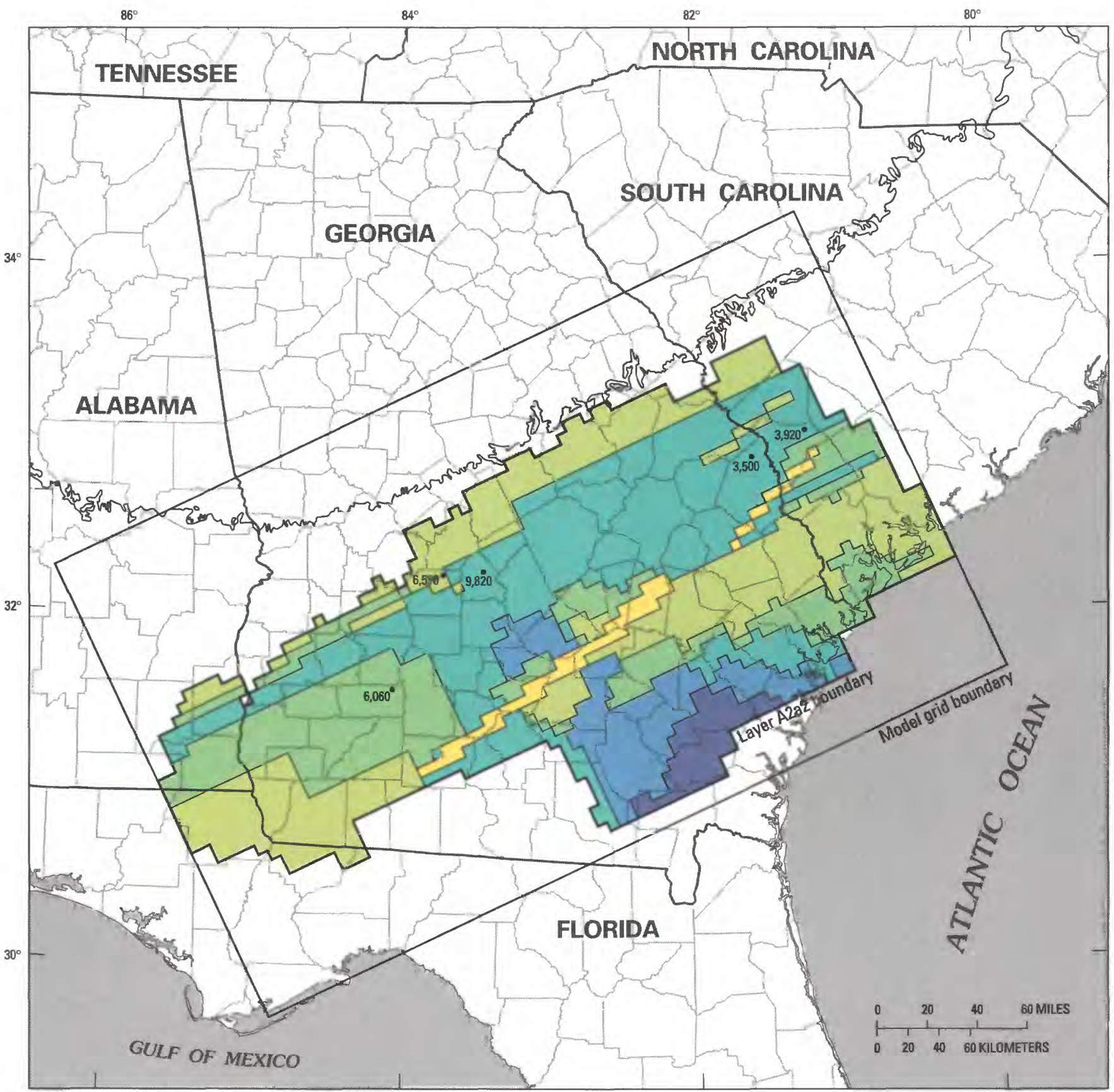

Base reduced from U.S. Geological Survey digital data, 1:2,000,000, 1972

EXPLANATION

Transmissivity, in feet squared per day

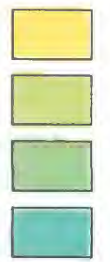
Less than 1,000
1,001 to 5,000
5,001 to 10,000
10,001 to 20,000

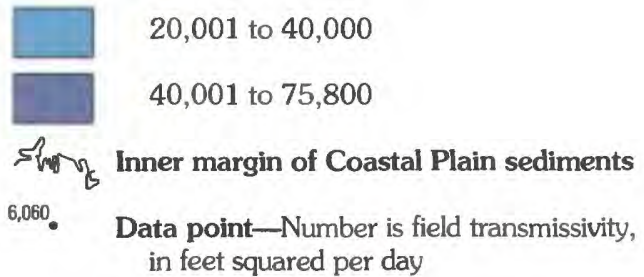

FIGURE 22. - Calibrated transmissivity distribution for model layer A2a2 (Tallahatta-Gordon aquifer). 


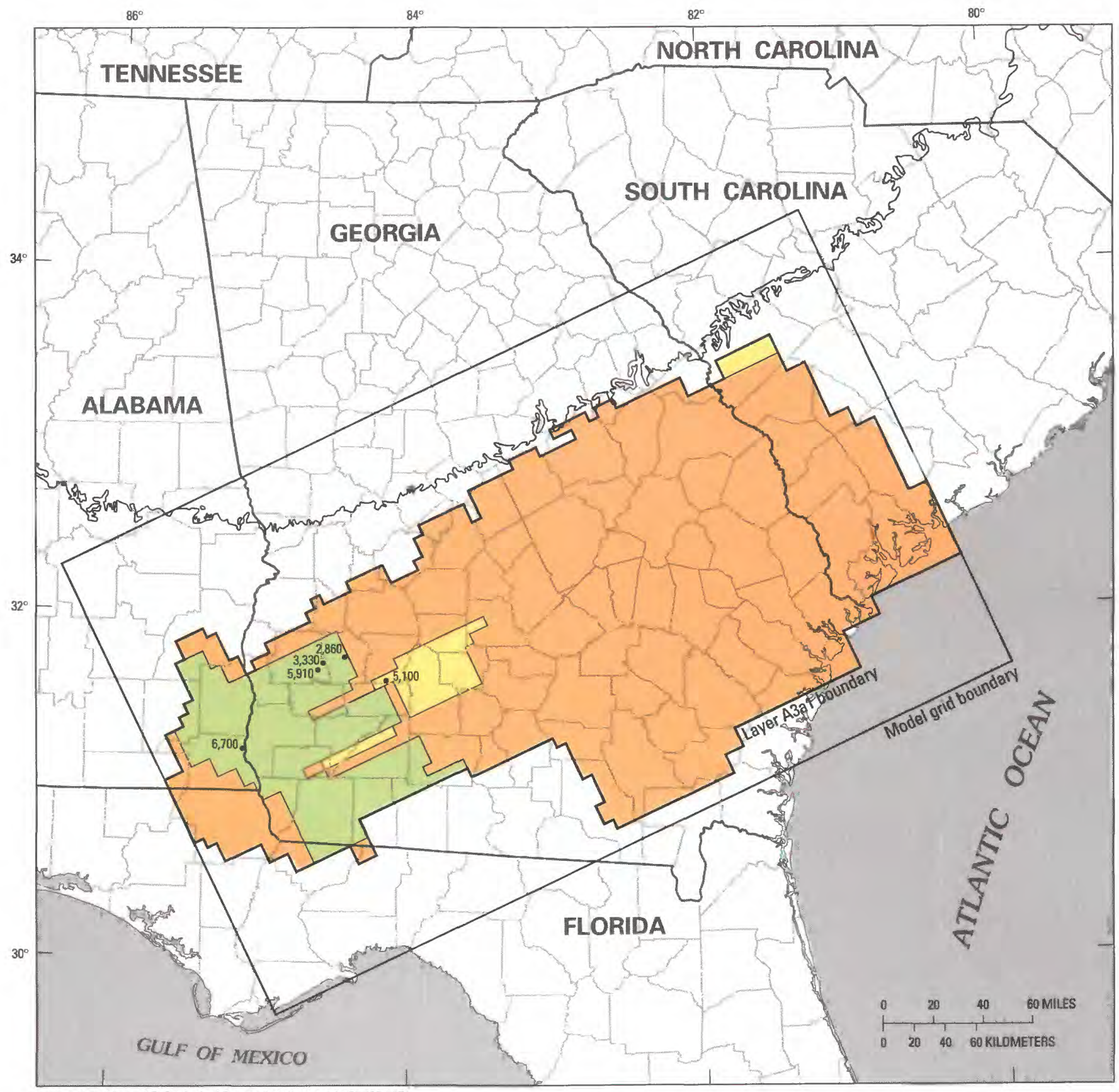

Base reduced from U.S. Geological Survey digital data, 1:2,000,000, 1972

EXPLANATION

Transmissivity, in feet squared per day

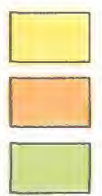

Less than 1,000

1,001 to 2,000

2,001 to 5,000
Sirng Inner margin of Coastal Plain sediments

6.700. Data point-Number is field transmissivity, in feet squared per day

Figure 23. - Calibrated transmissivity distribution for model layer A3a1 (Clayton-Ellenton aquifer). 


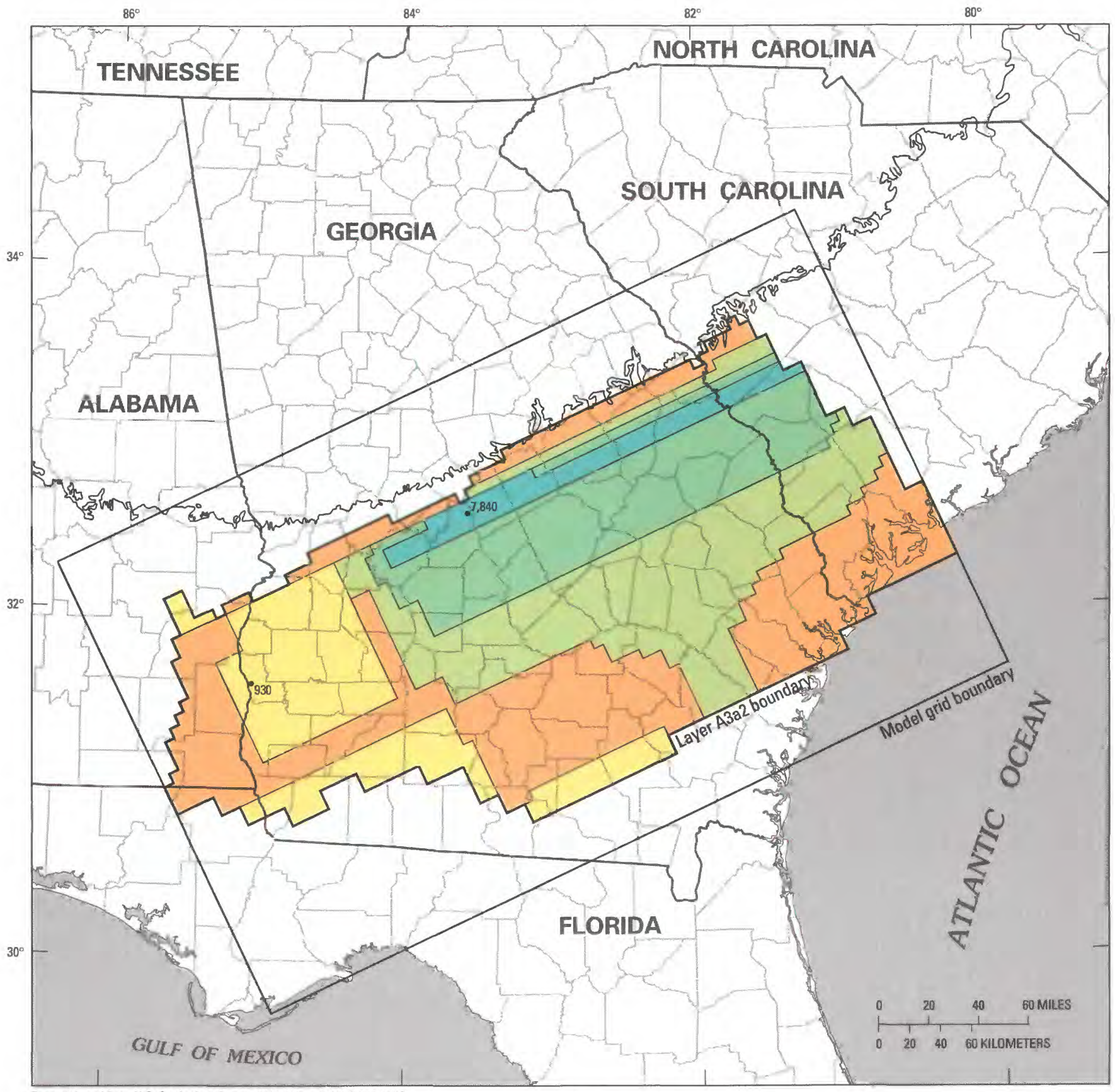

Base reduced from U.S. Geological Survey digital data, 1:2,000,000, 1972 EXPLANATION

Transmissivity, in feet squared per day

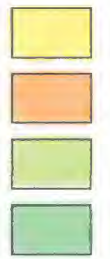
Less than 1.000
1,001 to 2,000
2,001 to 5,000
5,001 to 10,000

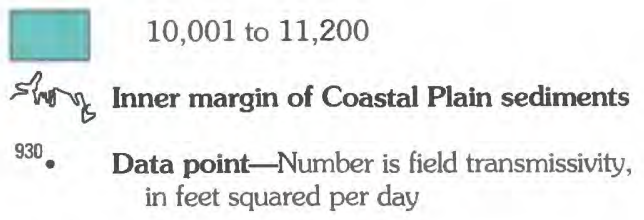

FIGURE 24. - Calibrated transmissivity distribution for model layer A3a2 (Providence Sand-Peedee aquifer). 


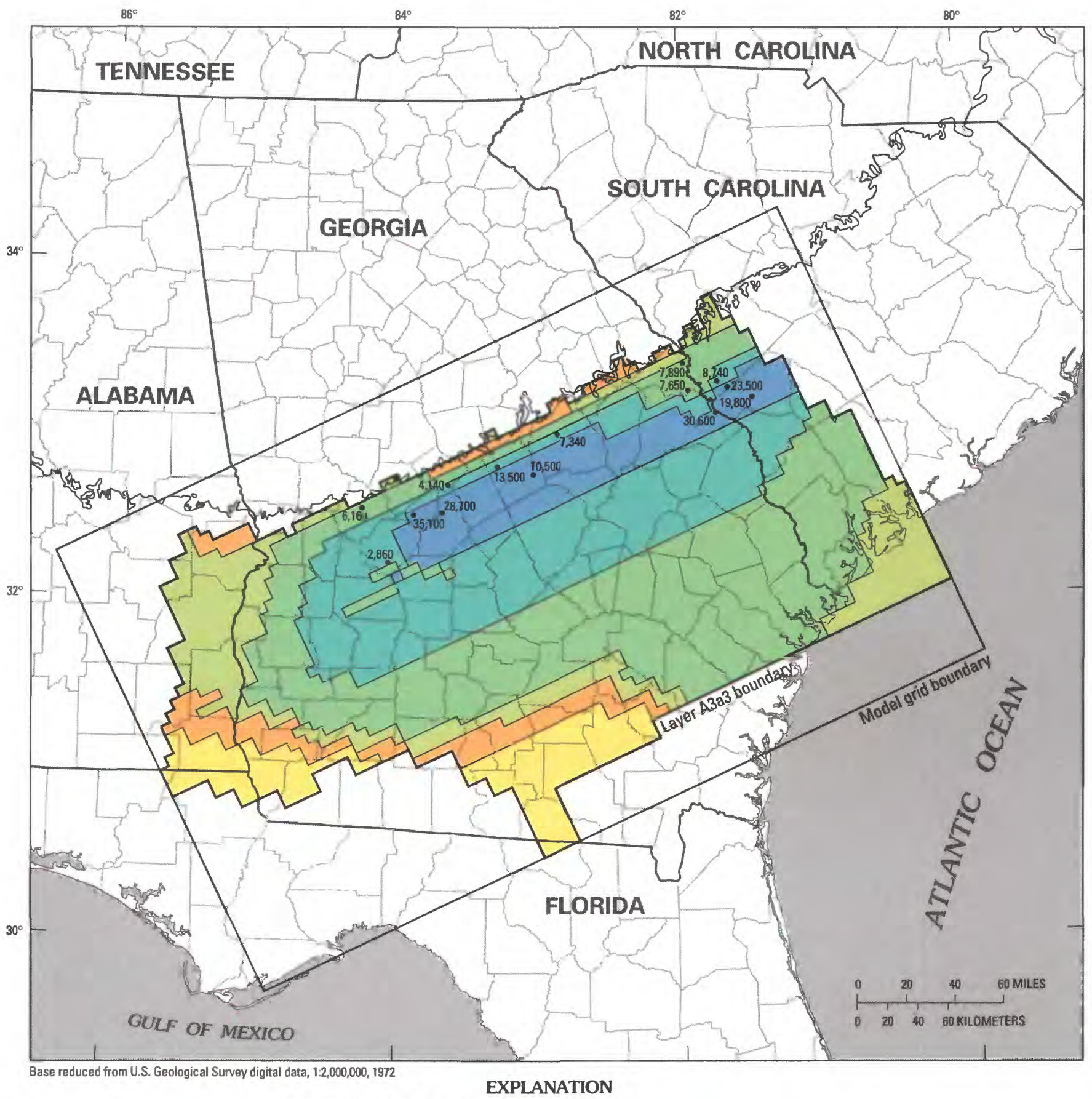

Transmissivity, in feet squared per day

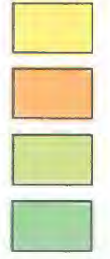

Less than 1,000

1,001 to 2,000

2,001 to 5,000

5,001 to 10,000

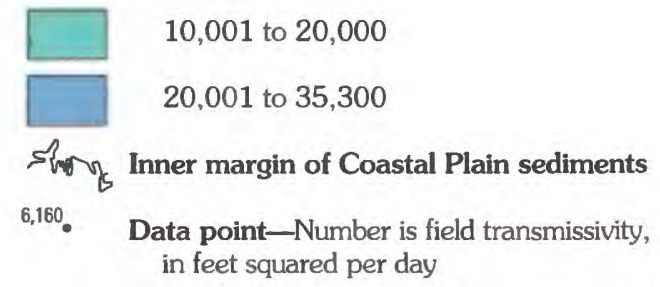

FIGURE 25. - Calibrated transmissivity distribution for model layer A3a3 (Eutaw-Midville aquifer). 


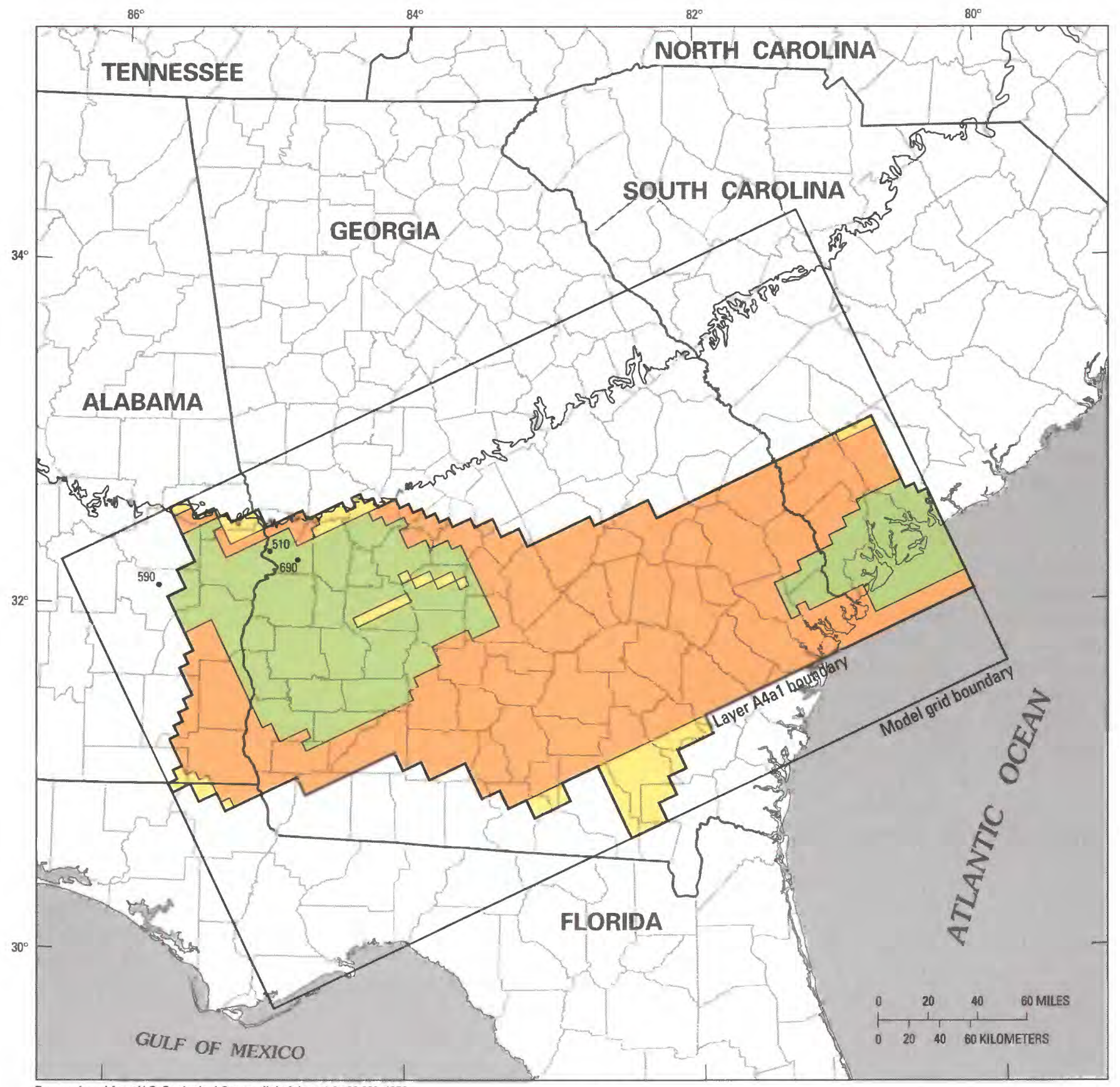

Base reduced from U.S. Geological Survey digital data, 1:2,000,000, 1972

\section{EXPLANATION}

Transmissivity, in feet squared per day

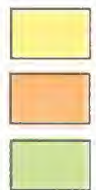

Less than 1,000

1,001 to 2,000

2,001 to 4,000

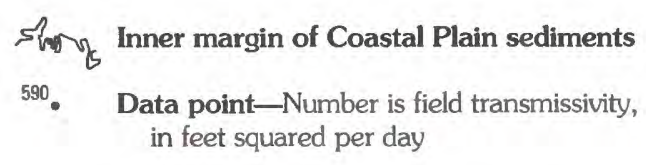
in feet squared per day

FIGURE 26. -Calibrated transmissivity distribution for model layer A4a1 (upper Atkinson-upper Tuscaloosa aquifer). 
TABLE 7.-Summary of calibrated transmissivity values

\begin{tabular}{crrr}
\hline & \multicolumn{3}{c}{$\begin{array}{c}\text { Transmissivity values } \\
\text { (feet squared per day) }\end{array}$} \\
\cline { 2 - 4 } $\begin{array}{c}\text { Model } \\
\text { layer }\end{array}$ & Minimum & Maximum & Mean \\
\hline A2a2 $\ldots \ldots \ldots \ldots \ldots$ & 70 & 75,800 & 11,200 \\
A3a1 $\ldots \ldots \ldots \ldots \ldots$ & 250 & 5,000 & 1,700 \\
A3a2 $\ldots \ldots \ldots \ldots \ldots$ & 250 & 11,200 & 3,600 \\
A3a3 $\ldots \ldots \ldots \ldots \ldots$ & 500 & 35,300 & 11,200 \\
A4a1 $\ldots \ldots \ldots \ldots \ldots$ & 250 & 4,000 & 1,900 \\
\hline
\end{tabular}

interpolated head values at a particular cell may be in excess of $50 \mathrm{ft}$. Elsewhere, differences generally were less than $20 \mathrm{ft}$.

Aquifer heads computed by the digital model were considered to have satisfactorily simulated field conditions at individual nodes when differences between computed hydraulic heads and interpolated field heads were less than $\pm 15 \mathrm{ft}$. Field head data near regional drains and other large streams in the northern part of the subregion were obtained, for the most part, from shallow wells and were relatively abundant. Because of the vertical distribution of hydraulic head described previously for the conceptual model, heads from these wells were generally considered lower limits of calibration. Conversely, field heads from wells in the vicinity of major drainage divides were generally considered upper limits for calibration.

Net recharge rates were calibrated initially by assigning a specified head to all cells that corresponded to outcrop locations of aquifer sediments. These cells were within the areas of possible direct recharge delimited on figures 17-21. Each direct recharge area represents those nodes of the specified model layer not overlain by nodes of the next highest layer, and approximates the area of outcrop of aquifer sediments. The specified-head values were representative of the average water-table altitude in each cell, as determined from topographic and preliminary potentiometric maps. The initial number of specified-head cells represented less than 10 percent of the total active cells for any model layer. After preliminary calibration of predevelopment conditions for the entire model, those specified-head cells that represented a source of water to the model were converted to specified-flux, net recharge cells at the model-computed rate. Specified-head cells, other than river cells, that represented a point of discharge were converted to active cells with zero specified flux. This process was repeated iteratively in conjunction with slight adjustments to selected riverbed conductances and cell transmissivities until satisfactory rates of net recharge were obtained and predetermined calibration criteria were satisfied.
TABLE 8.-Summary of calibrated leakance values

\begin{tabular}{cccc}
\hline \multirow{2}{*}{$\begin{array}{c}\text { Model } \\
\text { layer }\end{array}$} & \multicolumn{3}{c}{ Leakance values (seconds ${ }^{-1}$ ) } \\
\cline { 2 - 4 } Minimum & Maximum & Mean \\
\hline A2c1 $\ldots \ldots \ldots \ldots \ldots$ & $5.0 \times 10^{-12}$ & $1.0 \times 10^{-9}$ & $3.7 \times 10^{-10}$ \\
C2 $\ldots \ldots \ldots \ldots \ldots$ & $2.0 \times 10^{-13}$ & $9.9 \times 10^{-9}$ & $4.8 \times 10^{-10}$ \\
A3c1 $\ldots \ldots \ldots \ldots$ & $5.3 \times 10^{-12}$ & $1.5 \times 10^{-9}$ & $1.3 \times 10^{-10}$ \\
A3c2 $\ldots \ldots \ldots \ldots$ & $4.0 \times 10^{-13}$ & $4.1 \times 10^{-8}$ & $4.1 \times 10^{-10}$ \\
C3 $\ldots \ldots \ldots \ldots \ldots$ & $1.0 \times 10^{-13}$ & $1.6 \times 10^{-9}$ & $6.7 \times 10^{-11}$ \\
\hline
\end{tabular}

\section{PREDEVELOPMENT (STEADY-STATE) SIMULATIONS OF} GROUND-WATER FLOW

Initial calibration of the steady-state model provided preliminary estimates of model layer transmissivity, net recharge, aquifer discharge to regional drains, river node characteristics, and confining-unit leakance. Because transient conditions, as reflected by water-level declines, are minimal or occur only locally throughout most of the study area, the steady-state calibration was the major calibration effort.

During steady-state calibration, model results were compared with 763 field head values extrapolated to grid cell centers and to elements of the hydrologic budget, particularly regional flow regime discharge to regional drains and downgradient discharge (table 5). Predevelopment field heads interpolated to grid cell centers and predevelopment potentiometric contours computed by the final calibrated model are shown, by model layer at 50 -ft contour intervals, in plates 5-9. Shown in figure 32 are corresponding summaries of computed discharges to streams, specified net recharge rates, computed net leakage rates between layers, and computed net flux at boundary specified heads. All budget quantities shown in figure 32 represent mean annual rates for the predevelopment period. All river nodes were simulated as points of subregional aquifer discharge by the predevelopment (steady-state) model.

The simulated, predevelopment potentiometric contours match well with interpolated field heads for most model layers. For layer A2a2 (pl. 5), comparison of

TABLE 9.-Summary of calibrated recharge rates

\begin{tabular}{|c|c|c|c|c|}
\hline \multirow[b]{2}{*}{$\begin{array}{l}\text { Model } \\
\text { layer }\end{array}$} & \multirow{2}{*}{$\begin{array}{l}\text { Number } \\
\text { of } \\
\text { recharge } \\
\text { cells }\end{array}$} & \multicolumn{3}{|c|}{ Recharge rates (inches per year) } \\
\hline & & Minimum & Maximum & $\begin{array}{c}\text { Mean } \\
\text { for layer }\end{array}$ \\
\hline $\mathrm{A} 2 \mathrm{a} 2$. & 65 & 0.002 & 6.91 & 1.98 \\
\hline A3a1 ... & 45 & .0002 & 6.93 & .94 \\
\hline $\mathrm{A} 3 \mathrm{a} 2 \ldots \ldots \ldots \ldots$ & 117 & .0003 & 9.54 & 1.91 \\
\hline $\mathrm{A} 3 \mathrm{a} 3 \ldots \ldots \ldots$ & 56 & .004 & 7.56 & 2.77 \\
\hline $\mathrm{A} 4 \mathrm{al} \ldots \ldots \ldots \ldots$ & 33 & .0005 & 3.97 & .50 \\
\hline
\end{tabular}




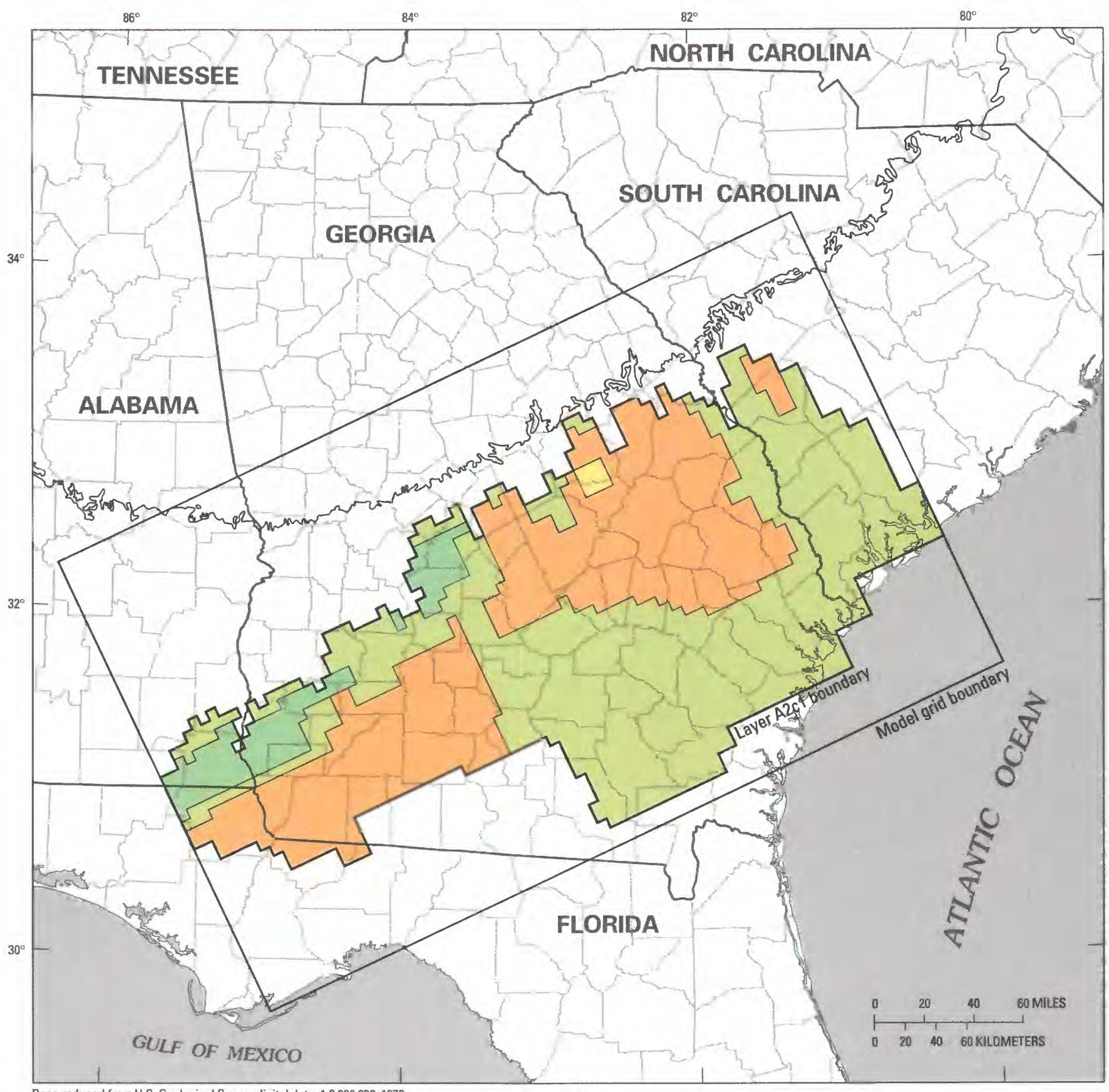

Base reduced from U.S. Geological Survey digital data, 1:2,000,000, 1972

Leakance, in 1 per second

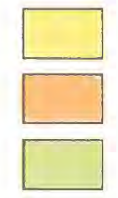
$5.0 \times 10^{-12}$
$1.0 \times 10^{-11}$ to $5.0 \times 10^{-11}$
$1.0 \times 10^{-10}$ to $8.0 \times 10^{-10}$

$1.0 \times 10^{-9}$

Sfory Inner margin of Coastal Plain sediments

FIGURE 27.-Calibrated leakance distribution for model layer A2c1 (Lisbon-McBean confining unit). 


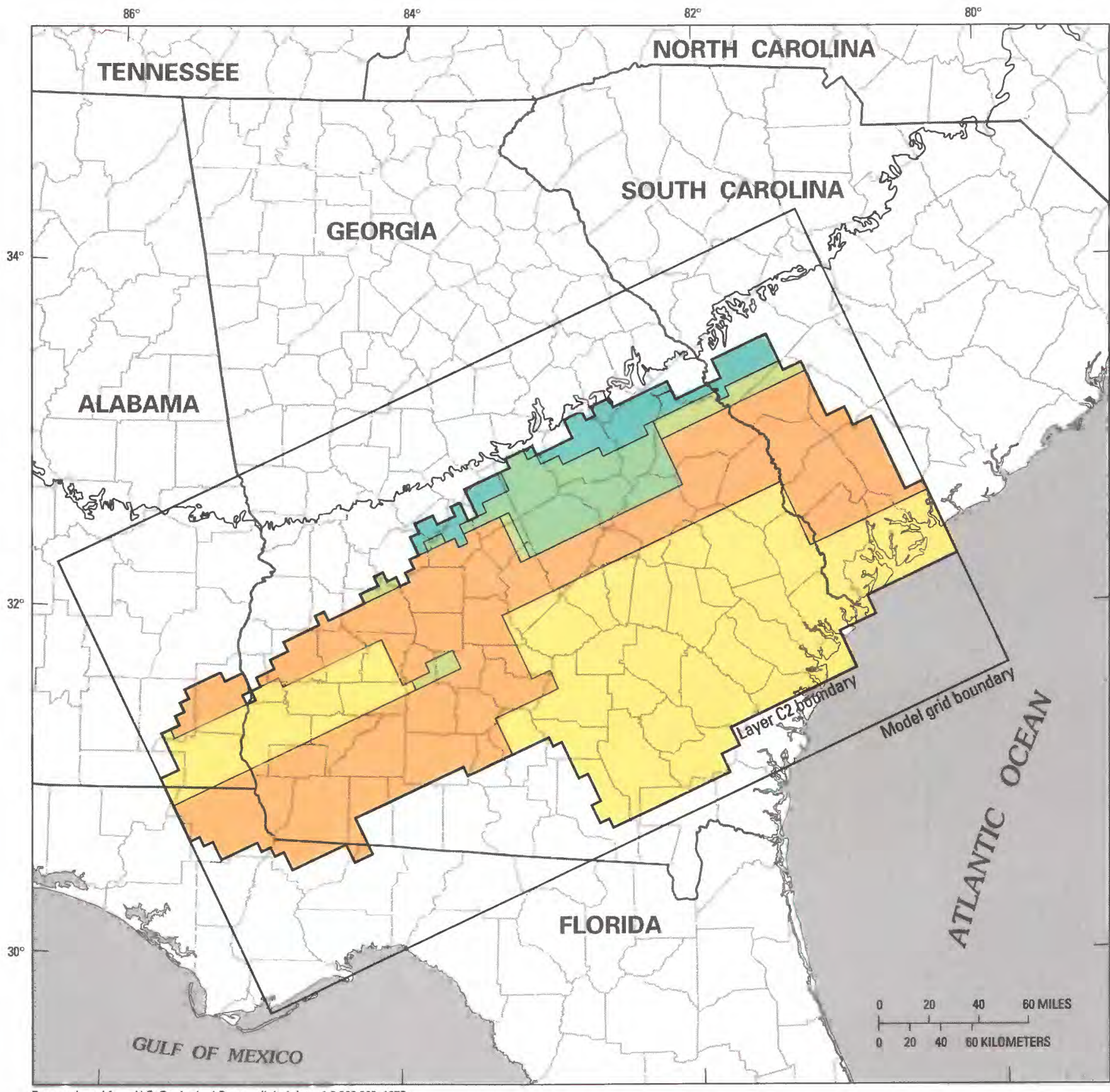

Base reduced from U.S. Geological Survey digital data, 1:2,000,000, 1972

\section{EXPLANATION}

Leakance, in 1 per second

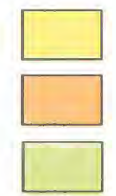

$$
\begin{aligned}
& 2.0 \times 10^{-13} \text { to } 7.0 \times 10^{-13} \\
& 2.0 \times 10^{-12} \text { to } 9.0 \times 10^{-12} \\
& 2.2 \times 10^{-11} \text { to } 9.2 \times 10^{-11}
\end{aligned}
$$

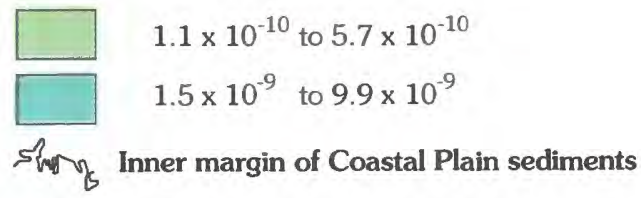

FIGURE 28.-Calibrated leakance distribution for model layer C2 (Tuscahoma-Fishburne confining unit). 


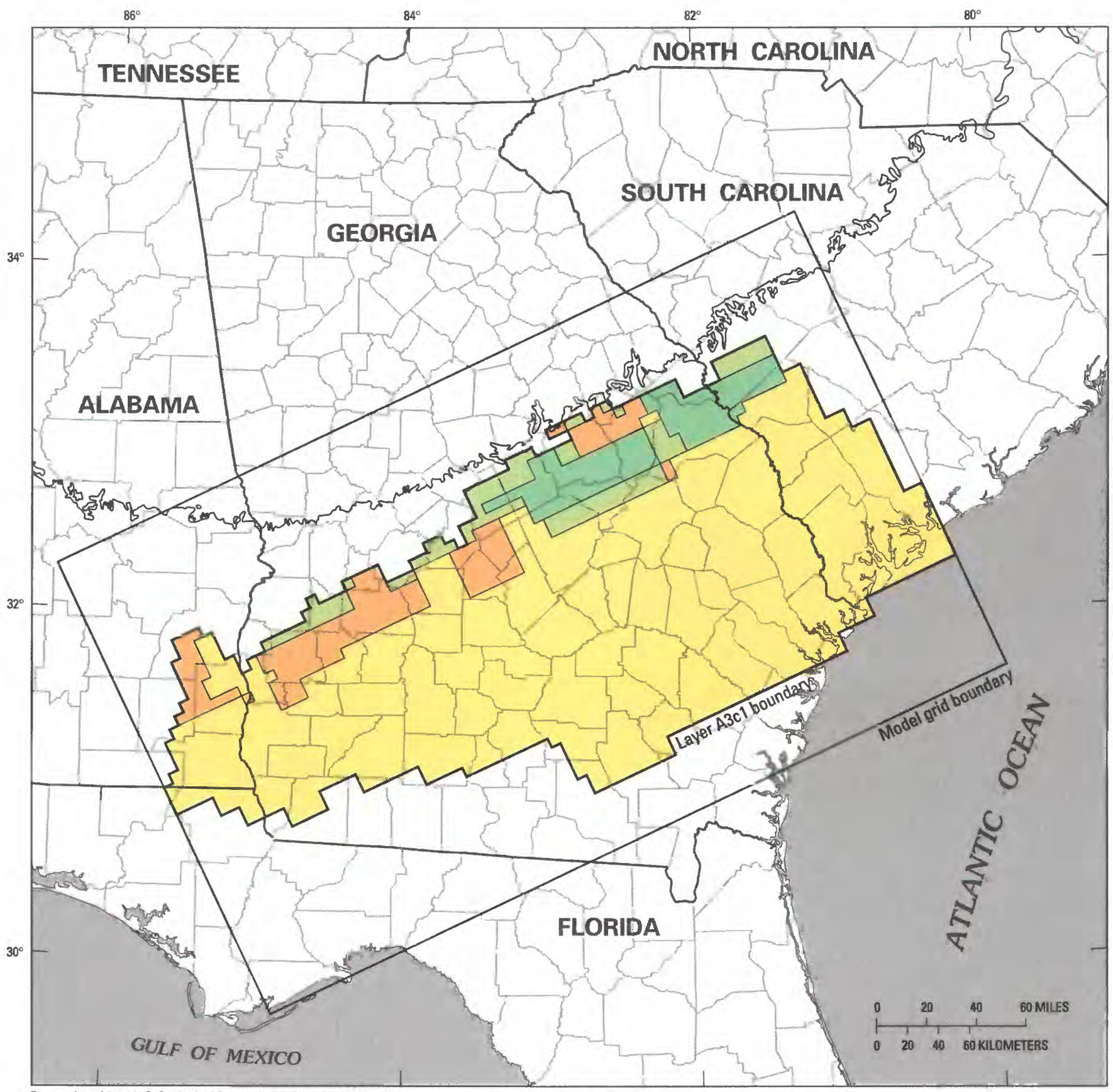

Base reduced from U.S. Geological Survey digital data, 1:2,000,000, 1972

Leakance, in 1 per second

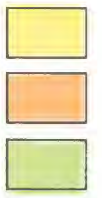
$5.3 \times 10^{-12}$
$5.3 \times 10^{-11}$ to $9.5 \times 10^{-11}$
$3.0 \times 10^{-10}$ to $8.3 \times 10^{-10}$

$1.3 \times 10^{-9}$ to $1.5 \times 10^{-9}$

Sfory Inner margin of Coastal Plain sediments

FIGURE 29. -Calibrated leakance distribution for model layer A3c1 (Providence Sand-Peedee confining unit). 


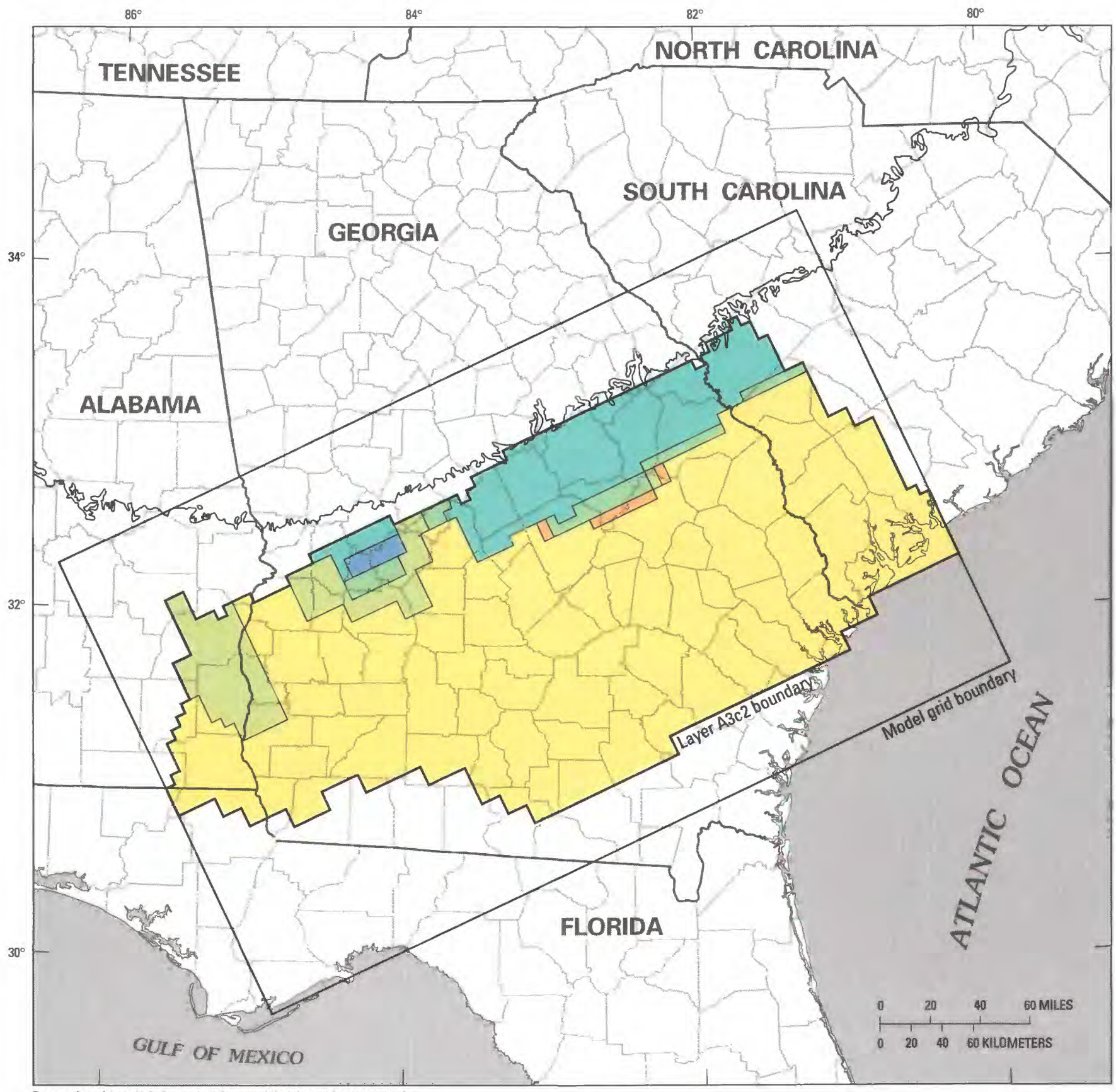

Base reduced from U.S. Geological Survey digital data, 1:2,000,000, 1972

\section{EXPLANATION}

Leakance, in 1 per second

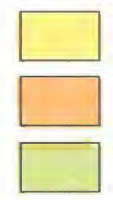
$4.0 \times 10^{-13}$
$4.0 \times 10^{-12}$
$1.4 \times 10^{-11}$ to $7.4 \times 10^{-11}$

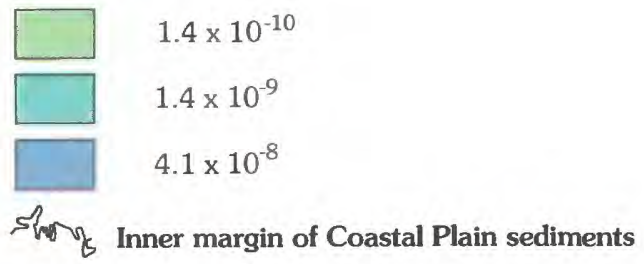

FIGURE 30. - Calibrated leakance distribution for model layer A3c2 (Ripley-Black Creek confining unit). 


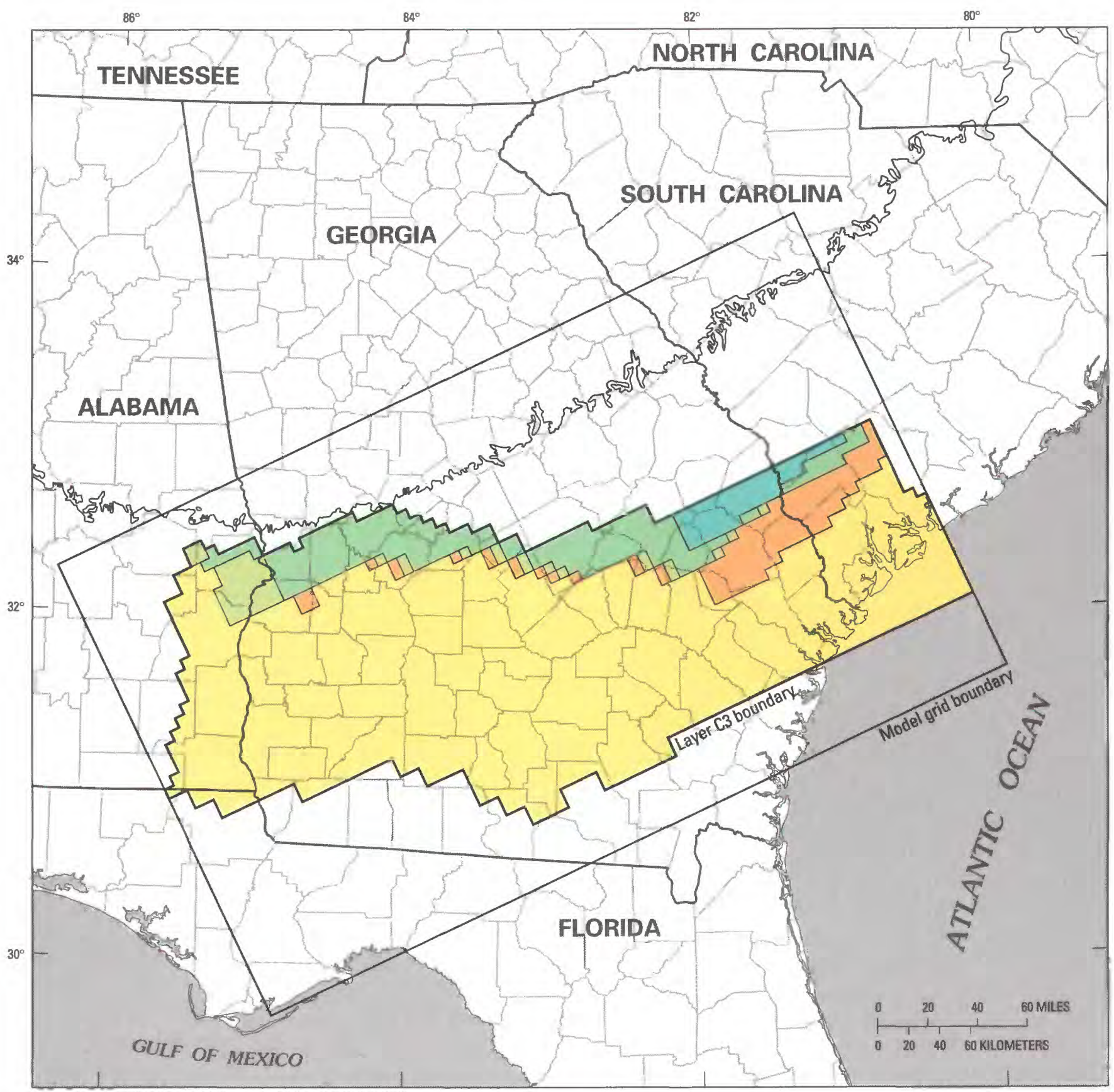

Base reduced from U.S. Geological Survey digital data, 1:2,000,000, 1972

Leakance, in 1 per second

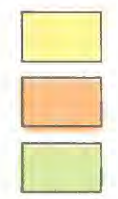
$1.0 \times 10^{-13}$
$1.0 \times 10^{-12}$ to $6.0 \times 10^{-12}$
$1.0 \times 10^{-11}$ to $6.0 \times 10^{-11}$

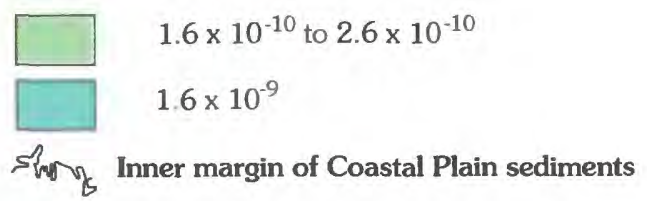

FIGURE 31.-Calibrated leakance distribution for model layer C3 (Eutaw-Cape Fear confining unit). 


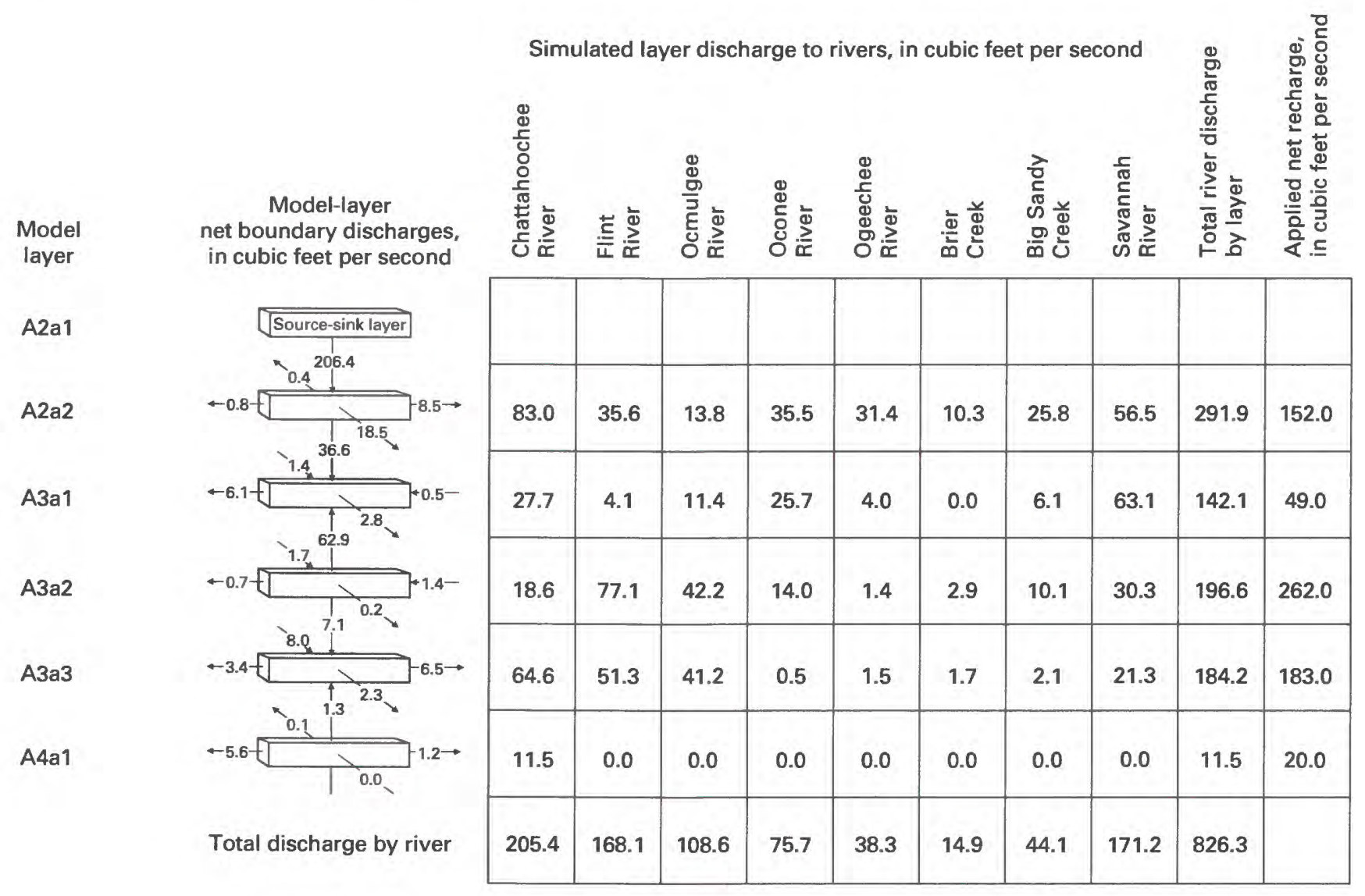

FIGURE 32. - Simulated components of the predevelopment water budget, by model layer.

simulated predevelopment potentiometric contours with 259 interpolated field heads indicates good to excellent agreement (within $15 \mathrm{ft}$ ) in the vicinity of the Savannah and Ogeechee Rivers and in the south-central and southeastern parts of the subregion. Agreement also is generally good between the 150 - and 250 -ft contours in the southwestern and central parts of the study area. Where areas of outcrop of aquifer sediments represented by model layer A2a2 occur along the northern and northwestern limits of the study area, the potentiometric surface is highly irregular and generally represents a subdued replica of surface topography. Accordingly, field heads may be somewhat lower than simulated heads in the vicinity of streams and rivers, and somewhat higher in the vicinity of major stream divides. Such differences are to be expected, given the hydraulic head distribution with depth in the vicinity of major streams and divides (fig. 14) and the preponderance of field data collected from shallow wells or wells that penetrate only the uppermost part of the aquifer. Examples of divergence between simulated and field predevelopment head data in the vicinity of major divides are shown between the Ocmulgee and Oconee Rivers near Danville and Montrose, Ga., and between the Flint and Ocmulgee
Rivers northeast of Cordele, Ga. Similar but directionally opposite differences at stream valleys are shown at the little Choctawhatchee River in southeastern Dale County, Ala., and along the Flint River in Sumter County, Ga. (pl. 5).

The influence of regional drains on subregional ground-water flow in layer A2a2 is evident in both the field heads and in the configuration of simulated predevelopment potentiometric contours. Simulated flow in upgradient areas seems to be controlled largely by discharge to regional drains. This pattern of flow conforms well to the conceptual model of subregional ground-water flow. Downgradient of the river nodes, simulated predevelopment flow is seaward toward the Atlantic Ocean and toward the Gulf of Mexico. The relatively large hydraulic gradient in the south-central part of the subregion reflects flow across the northeasttrending Gulf trough, a zone of presumed low transmissivity for model layer A2a2 (Krause and Randolph, 1989).

Interpolated field heads (99 observations) for model layer A3a1 are limited to the eastern and westernmost parts of the study area. Simulated predevelopment potentiometric contours are uniformly similar to those described previously for model layer $\mathrm{A} 2 \mathrm{a} 2$, and agree 
TABLE 10.-Summary of statistical evaluations of the simulated predevelopment potentiometric surfaces

\begin{tabular}{|c|c|c|c|c|c|c|}
\hline \multirow{2}{*}{$\begin{array}{l}\text { Model } \\
\text { layer }\end{array}$} & \multirow{2}{*}{$\begin{array}{l}\text { Number of } \\
\text { residuals }\end{array}$} & \multicolumn{3}{|c|}{ Residual quartile (feet) } & \multirow{2}{*}{$\begin{array}{l}\text { Number of } \\
\text { residuals } \\
\text { less than or } \\
\text { equal to } 15 \text { feet }\end{array}$} & \multirow{2}{*}{$\begin{array}{l}\text { Root mean } \\
\text { square error } \\
\text { (feet) }\end{array}$} \\
\hline & & First & Second & Third & & \\
\hline $\mathrm{A} 2 \mathrm{a} 2$ & 259 & 5.0 & 12.0 & 19.0 & 158 & 20.2 \\
\hline A3a1. & 99 & 4.0 & 13.0 & 20.0 & 56 & 19.2 \\
\hline $\mathrm{A} 3 \mathrm{a} 2$. & 160 & 6.0 & 11.0 & 21.0 & 104 & 20.4 \\
\hline A3a3 $\ldots . . . .$. & 198 & 5.0 & 11.0 & 18.0 & 130 & 21.0 \\
\hline A4a1 $\ldots \ldots \ldots \ldots$ & 47 & 9.0 & 15.0 & 28.0 & 24 & 23.5 \\
\hline All layers ... & 763 & 5.0 & 12.0 & 20.0 & 472 & 20.5 \\
\hline
\end{tabular}

well with interpolated field heads, where comparisons can be made (pl. 6). Potentiometric features characteristic of homoclinal flanks (LeGrand and Pettyjohn, 1981) were simulated by the model downstream of the outcrop area along the Chattahoochee and Savannah Rivers. In the central and eastern parts of the model layer, predevelopment downgradient flow is simulated to the southeast toward the Atlantic Ocean and toward an area of local discharge in southwestern South Carolina, which generally is delimited by the 100 -ft contour. Simulated downgradient flow in the western part of layer A3a1 generally is to the south and slightly toward the Chattahoochee River. Simulated predevelopment heads are shown to be higher than interpolated field heads along the Chattahoochee River in central Clay County, Ga., and near the Flint River in southwestern Dooly County, Ga. (pl. 6).

Simulated, homoclinal potentiometric features also occurred along the Chattahoochee and Savannah Rivers in model layer A3a2 (pl. 7). These homoclinal features correspond closely to interpolated field heads, as do the simulated predevelopment potentiometric contours across most of the upgradient parts of the model layer. Predevelopment simulations also correspond closely to limited field data in the southern half of the study area. Simulated downgradient flow generally is to the south and southeast, and the more southerly flow occurs west of the Ocmulgee River. Comparisons between simulated heads and interpolated field heads were made at 160 cells.

Simulated predevelopment potentiometric contours for model layer A3a3 are shown in plate 8. Agreement between simulated contours and interpolated field heads (198 observations) generally is within $15 \mathrm{ft}$, where comparisons can be made. The low heads noted in field observations along the Chattahoochee River may be the result of a natural cone of depression, a characteristic of homoclinal potentiometric features that was not simulated by the model. The Chattahoochee, Flint, and Savannah Rivers are represented in model layer A3a3 as major lines of simulated aquifer discharge in upgradient parts of the study area, a condition that is supported by field observations (table 4). Simulated predevelopment downgradient flow east of the Flint River seems to be to the east or slightly to the northeast. Downgradient flow in the western part of layer A3a3 seems to be to the south or slightly to the southwest. Simulated downgradient flow in the southeasternmost part of the subregion seems to be to the east and slightly to the northeast, and more parallel to than toward the Atlantic Ocean.

Simulated predevelopment potentiometric contours for model layer A4a1 and corresponding interpolated field heads (47 observations) are shown in plate 9 . The occurrence of field heads is limited almost exclusively to the northwestern part of the model layer. Agreement between interpolated field heads and simulated contours, including comparisons made near the simulated homoclinal potentiometric feature along the Chattahoochee River, is generally within $20 \mathrm{ft}$. Elsewhere in model layer A4a1, simulated contours largely are uncorroborated, the exception being several measurements from deep wells in Houston County, Ala., Liberty County, Ga., and Beaufort County, S.C. Simulated predevelopment flow in upgradient parts of the model layer generally is toward the Chattahoochee and Flint Rivers. West of the potentiometric divide between the Flint and Chattahoochee Rivers, predevelopment downgradient flow is to the west and slightly southeast. East of this divide, simulated downgradient flow is to the east and southwest, except in southeastern Georgia and adjacent parts of South Carolina, where simulated flow is parallel to the Atlantic coastal margin.

The quality of the final steady-state model calibration was evaluated in part by comparing simulated heads to interpolated field heads. The absolute difference between a simulated head and field head is herein termed a residual. Table 10 presents an elementary statistical description of the final calibrated steady-state model, in terms of residuals and absolute error. In table 10, quartiles of residuals are presented, as well as the number of residuals that are less than or equal to the 15-ft calibration criterion. Root mean square (RMS) 
error also is presented and may be used to compare the quality of the calibration by layer. The RMS error was calculated using the following equation:

where

$$
\mathrm{RMS}=\sqrt{\sum_{i=1}^{N}\left(h_{s}-h_{f}\right)^{2} / N}
$$

$N$ is the number of head comparisons;

$h_{s}$ is the simulated head; and

$h_{f}$ is the interpolated field head.

The RMS error decreases as the sum of the squared differences between simulated heads and interpolated field heads is reduced.

From table 10 it can be seen, for example, that for model layer A3a2 there are 160 comparisons, of which 25 percent produced residuals less than or equal to $6 \mathrm{ft}$. Seventy-five percent of the residuals are less than or equal to $21 \mathrm{ft}$. The median residual of layer A3a2 is $11 \mathrm{ft}$. Of these 160 comparisons, 104 residuals, or 65 percent, are less than or equal to $15 \mathrm{ft}$. The RMS value indicates that layer $\mathrm{A} 3 \mathrm{a} 2$ is the median of calibration quality because two layers calibrated slightly better and two layers slightly worse. Evaluation of RMS indicates that calibration probably was best for model layer A3a1 and worst for layer A4a1.

The quality of calibration based on comparisons of simulated to interpolated field heads also appears to be well distributed by layer. For the entire final steadystate model, 472 of the 763 residuals, or 62 percent, are less than or equal to the 15 -ft calibration criterion, and 75 percent, or 572 residuals, are less than or equal to $20 \mathrm{ft}$.

Components of the simulated predevelopment budget are summarized in figure 32. Net leakage from the source-sink layer (A2a1) to the underlying layer (A2a2) was about $206 \mathrm{ft}^{3} / \mathrm{s}$, which results from a difference between a total downward leakage of $574 \mathrm{ft}^{3} / \mathrm{s}$ and an upward leakage of $368 \mathrm{ft}^{3} / \mathrm{s}$. Total simulated aquifer discharge to regional drains and other streams was 826 $\mathrm{ft}^{3} / \mathrm{s}$. Horizontal flow to specified heads at model layer boundaries was about $57 \mathrm{ft}^{3} / \mathrm{s}$. Simulated applied net recharge equaled $666 \mathrm{ft}^{3} / \mathrm{s}$. Recharge from specified heads at boundaries was about $13 \mathrm{ft}^{3} / \mathrm{s}$. A difference of 2 $\mathrm{ft}^{3} / \mathrm{s}$ in a mass balance of these numbers is attributed to cumulative round-off and truncation error during model computations.

Several elements in the model budget compare favorably to corresponding components in the hydrologic budget described previously (table 6). The discharge from the regional flow regime to regional drains of 780 $\mathrm{ft}^{3} / \mathrm{s}$ computed for the hydrologic budget (table 6) did not include equivalent aquifer discharges to Big Sandy Creek or Brier Creek. These discharges represent $59 \mathrm{ft}^{3} / \mathrm{s}$ in the calibrated steady-state model, which, when removed from total simulated stream discharge, provide a total simulated predevelopment discharge to regional drains of $767 \mathrm{ft}^{3} / \mathrm{s}$. Accordingly, values of model-computed and independently computed total discharge to regional drains agree within a difference of $13 \mathrm{ft}^{3} / \mathrm{s}$, or about 2 percent.

Downgradient discharge computed for the hydrologic budget was about $310 \mathrm{ft}^{3} / \mathrm{s}$ (table 6). A comparable simulated value can be computed by subtracting total simulated stream discharge from total recharge to the model. Total simulated recharge is the sum of applied net recharge (fig. 32) and downward leakage from the source-sink layer, a value of about $1,240 \mathrm{ft}^{3} / \mathrm{s}$. The difference between total model recharge and total simulated stream discharge is then about $414 \mathrm{ft}^{3} / \mathrm{s}$, which exceeds the corresponding hydrologic budget component for downgradient discharge by about $100 \mathrm{ft}^{3} / \mathrm{s}$, or about 34 percent. Note also that total recharge to the regional flow regime computed for the hydrologic budget (table 6) was about $1,100 \mathrm{ft}^{3} / \mathrm{s}\left(780 \mathrm{ft}^{3} / \mathrm{s}\right.$ plus $\left.310 \mathrm{ft}^{3} / \mathrm{s}\right)$.

\section{SENSITIVITY ANALYSES OF STEADY-STATE MODEL}

Although the final calibrated steady-state model was adequately tested against potentiometric data and a hydrologic budget, the sensitivity of the calibration to changes in input data was unknown. A sensitivity analysis was used to quantitatively evaluate the effects of changes to input parameters by singularly adjusting the parameters and comparing the simulated results to 763 interpolated field heads and elements of the computed predevelopment budget. The deviation of the simulated response from that of the calibrated model is considered a qualitative measure of the sensitivity of the model to variation in the adjusted input parameter.

The sensitivity of the model was tested by uniformly adjusting recharge, leakance, and transmissivity by factors of $0.5,2.0$, and 10.0 throughout the model. One simulation was made for each parameter change, while all other parameters remained unchanged. Sensitivity simulations were evaluated with respect to changes in head (RMS) and budget components, as shown in table 11. All references to changes or differences are with respect to results of the final calibrated steady-state model.

Simulated heads and stream discharges seem to be most sensitive to changes in recharge and transmissivity and seem relatively insensitive to variations in leakance. Increasing recharge rates by a factor of 2.0 over calibrated values resulted in about a 60 -percent increase in corresponding total river discharge. The increased recharge also reversed the direction of net vertical leakage simulated by the calibrated model and increased boundary discharge by about 150 percent. The corre- 
TABLE 11.-Summary of sensitivity analyses of steady-state model simulations $[-$, up; +, down $]$

\begin{tabular}{|c|c|c|c|c|c|}
\hline $\begin{array}{c}\text { Model } \\
\text { parameter }\end{array}$ & Factor & $\begin{array}{c}\text { Root mean } \\
\text { square } \\
\text { error } \\
\text { (feet) }\end{array}$ & $\begin{array}{l}\text { Total river } \\
\text { discharge } \\
\text { (cubic feet } \\
\text { per second) }\end{array}$ & $\begin{array}{l}\text { Net vertical } \\
\text { leakage } \\
\text { (cubic feet } \\
\text { per second) }\end{array}$ & $\begin{array}{l}\text { Net horizontal } \\
\text { boundary discharge } \\
\text { from model } \\
\text { (cubic feet } \\
\text { per second) }\end{array}$ \\
\hline Calibrated ........... & 1.0 & 20.5 & 825 & +186 & 43 \\
\hline Leakance ........... & .5 & 23.2 & 807 & +78 & 41 \\
\hline Leakance ........... & 2.0 & 21.3 & 945 & +339 & 41 \\
\hline Leakance ........... & 10.0 & 29.0 & 1,224 & +751 & 52 \\
\hline Recharge.....$\ldots \ldots$ & .5 & 42.9 & 647 & +37 & 9 \\
\hline Recharge...$\ldots \ldots \ldots$ & 2.0 & 85.9 & 1,339 & -96 & 105 \\
\hline Recharge....$\ldots \ldots$. & 10.0 & 271.6 & 5,059 & $-2,380$ & 614 \\
\hline Transmissivity........ & .5 & 66.0 & 779 & +120 & 42 \\
\hline Transmissivity........ & 2.0 & 36.9 & 988 & +242 & 40 \\
\hline Transmissivity........ & 10.0 & 68.4 & 1,271 & +314 & 100 \\
\hline
\end{tabular}

sponding effect on hydraulic heads was to raise the simulated heads substantially, as indicated by the RMS (table 11). The change in simulated heads was greatest in the recharge areas of the lower model layers. Increasing recharge by a factor of 10.0 produced a much larger but qualitatively similar response to that produced by doubling the recharge. Reducing recharge by a factor of 0.5 reduced the total river discharge to about 80 percent of the calibrated value and generally lowered the simulated heads throughout the model. Vertical, downward leakage from the specified-head layer A2a1 was substantially higher than calibrated leakage, whereas net boundary discharge from the model was reduced by about 90 percent from calibrated values.

Increasing transmissivity by a factor of 2.0 did not produce as great a response as reducing transmissivity by a factor of 0.5 or increasing it by a factor of 10.0. Doubling the transmissivity resulted in a slight increase over calibrated values for river discharge and net downward leakage (table 11). The simulated heads generally were slightly lower than calibrated values near recharge areas and slightly higher in the downgradient parts of each layer, except for layer A4a1, where heads were slightly lower nearly everywhere. Reducing transmissivity by a factor of 0.5 resulted in slightly less stream discharge and net downward leakage compared with calibrated rates. Simulated heads generally were higher than calibrated heads near recharge areas, and were slightly lower in downgradient parts of the model. Increasing transmissivity by a factor of 10.0 increased river discharge by about 60 percent over the calibrated total river discharge, and increased the net boundary discharge by about 150 percent. The increase shown for net vertical leakage was mostly from the specified-head, source-sink layer A2a1 near the rivers. Simulated heads were substantially lower than calibrated values near recharge areas, and substantially higher downgradient using transmissivities at 10 times their calibrated values.

Adjusting leakance produced only relatively minor changes in calibrated heads. However, simulated stream discharge and net vertical leakage changed substantially and directly in response to changes in leakance. Increasing leakance by a factor of 10 , compared with calibrated values, increased stream discharge by about 50 percent and net vertical leakage by about 400 percent.

\section{SIMULATION OF TRANSIENT GROUND-WATER FLOW}

Simulation of transient ground-water flow was used to evaluate the effects of ground-water pumping on subregional aquifers. Published references to ground-water pumping at various municipal, industrial, and agricultural pumping centers were described in the section above, "Data Sources and Previous Work." These data and unpublished ground-water-use data from U.S. Geological Survey files were tabulated by aquifer, year, well, and location at hundreds of sites within the study area. Based on trends and the temporal distribution of these data, five stress periods (1900-44, 1945-60, 1961-70, 1971-75, and 1976-80) were chosen to simulate the drawdown effects of ground-water pumping. Time was computed from January 1 of the first year to December 31 of the last year of each stress period. Additional days for leap years were ignored. Average pumping rates for each stress period were applied at the centers of cells where pumping occurred. Average rates were computed by assuming a linear increase in pumping between those years when withdrawal rates were reported. For example, at a given cell, reported withdrawals may have been $2.0 \mathrm{ft}^{3} / \mathrm{s}$ in 1976 and $6.0 \mathrm{ft}^{3} / \mathrm{s}$ in 1980 . Thus, the average pumping rate applied at that cell for the stress period $1976-80$ was $4.0 \mathrm{ft}^{3} / \mathrm{s}$. Frequently, pumping did not 
TABLE 12. - Summary of ground-water pumpage (in cubic feet per second), by stress period and use

\begin{tabular}{|c|c|c|c|c|c|}
\hline $\begin{array}{l}\text { Stress } \\
\text { period }\end{array}$ & $\begin{array}{l}\text { Model } \\
\text { layer }\end{array}$ & $\begin{array}{l}\text { Municipal } \\
\text { pumpage }\end{array}$ & $\begin{array}{l}\text { Industrial } \\
\text { pumpage }\end{array}$ & $\begin{array}{l}\text { Agricultural } \\
\text { pumpage }\end{array}$ & $\begin{array}{c}\text { Total } \\
\text { pumpage }\end{array}$ \\
\hline \multirow[t]{5}{*}{$1900-44 \ldots \ldots \ldots \ldots$} & A2a2 & 6.78 & - & - & 6.78 \\
\hline & A3a1 & 3.08 & - & - & 3.08 \\
\hline & $\mathrm{A} 3 \mathrm{a} 2$ & 2.33 & 1.20 & - & 3.53 \\
\hline & A3a3 & 2.47 & - & - & 2.47 \\
\hline & A4a1 & .03 & - & - & .03 \\
\hline \multicolumn{2}{|l|}{ Total $\ldots \ldots \ldots \ldots$} & 14.69 & 1.20 & - & 15.89 \\
\hline \multirow[t]{5}{*}{$1945-60 \ldots \ldots \ldots \ldots \ldots$} & A2a2 & 13.49 & 3.75 & - & 17.24 \\
\hline & A3a1 & 11.66 & 2.74 & - & 14.40 \\
\hline & $\mathrm{A} 3 \mathrm{a} 2$ & 11.40 & 11.73 & 0.20 & 23.39 \\
\hline & A3a3 & 9.52 & 6.76 & .30 & 16.58 \\
\hline & A4a1 & 1.75 & - & - & 1.75 \\
\hline \multicolumn{2}{|l|}{ Total $\ldots \ldots \ldots \ldots$} & 47.82 & 24.98 & .50 & 63.36 \\
\hline \multirow{5}{*}{$1961-70 \ldots \ldots \ldots \ldots$} & A2a2 & 19.52 & 10.30 & .43 & 30.25 \\
\hline & A3a1 & 19.97 & 21.24 & - & 41.21 \\
\hline & A3a2 & 18.30 & 41.56 & .50 & 60.36 \\
\hline & A3a3 & 20.85 & 24.25 & .20 & 45.30 \\
\hline & A4a1 & 4.18 & - & - & 4.18 \\
\hline \multicolumn{2}{|l|}{ Total ............ } & 82.82 & 97.35 & 1.13 & 181.30 \\
\hline \multirow[t]{5}{*}{$1971-75 \ldots \ldots \ldots \ldots \ldots$} & $\mathrm{A} 2 \mathrm{a} 2$ & 26.51 & 10.64 & .08 & 37.23 \\
\hline & A3a1 & 22.26 & 40.63 & .70 & 63.59 \\
\hline & A3a2 & 20.58 & 76.33 & .83 & 97.74 \\
\hline & A3a3 & 32.50 & 44.34 & .39 & 77.23 \\
\hline & A4a1 & 5.81 & - & - & 5.81 \\
\hline \multicolumn{2}{|l|}{ Total ............ } & 107.66 & 171.94 & 2.00 & 281.60 \\
\hline \multirow[t]{5}{*}{$1976-80 \ldots \ldots \ldots \ldots \ldots$} & $\mathrm{A} 2 \mathrm{a} 2$ & 28.25 & 12.77 & 21.19 & 62.21 \\
\hline & A3a1 & 34.56 & 14.50 & 21.01 & 70.07 \\
\hline & A3a2 & 28.87 & 113.90 & 2.19 & 144.96 \\
\hline & A3a3 & 32.48 & 55.49 & 3.03 & 91.00 \\
\hline & A4a1 & - & 6.41 & - & 6.41 \\
\hline \multicolumn{2}{|l|}{ Total ........... } & 124.16 & 203.07 & 47.42 & 374.65 \\
\hline
\end{tabular}

change substantially between reported years, or only a few pumping data were available for a site. Under such circumstances, the reported rate of pumping for a specific year within a stress period was applied to the whole stress period.

Total average ground-water pumping rates and rates for municipal, industrial, and agricultural withdrawals are shown in table 12 for each stress period. Agricultural withdrawals largely represent pumping for crop irrigation. Total average rates of withdrawal are shown distributed through the study area by county and by stress period in plate 10. Total average pumping within the study area increased from about $16 \mathrm{ft}^{3} / \mathrm{s}$ during the period 1900 to 1944 to about $375 \mathrm{ft}^{3} / \mathrm{s}$ during 1976 to 1980 . During the last stress period, about 12 percent of the total withdrawal was for erop irrigation. The pumping rates presented in table 12 and plate 10 probably are accurate to about \pm 25 pereent.

Boundary conditions, riverbed conductances and river stage values, transmissivity, and leakance matrices were identical for both the preliminary steady-state and initial transient flow simulations. The applied recharge distributions developed from the steady-state calibration are considered an approximation of long-term mean annual net recharge from precipitation to the regional flow regime and were also transferred directly to transient simulations. The simulated, predevelopment heads of the steady-state model were used as initial heads for the transient model. Large-scale ground-water pumping from the Barnwell-Upper Floridan aquifer resulted in substantial water-level declines in the vicinity of Savannah and in southeastern Georgia and southwestern South 
Carolina during 1900-80. These declines were accounted for in the source-sink model layer (A2a1) in a stepwise fashion by introducing to the model a modified specifiedhead distribution for layer A2a1 at the beginning of each of the five stress periods. Each distribution progressively lowered specified water levels through time. Specified-head potentiometric surfaces for the Upper Floridan aquifer in the Savannah area and vicinity were developed for each stress period from maps by Warren (1945) and Counts and Donsky (1963), and in surrounding areas from maps by Callahan (1964), Counts and Krause (1976), Johnston and others (1981), and Krause and Randolph (1989).

The storage properties of the aquifers were necessarily incorporated in the transient simulations. Initial estimates of storativity for the five active model layers were obtained from Clarke and others $(1983,1984,1985)$, Scott and others (1984), Brooks and others (1985), Gorday (1985), and Faye and McFadden (1986). Point storativity data were sparse and available only in the northern part of the subregion. Storativity data were most numerous for the Eutaw-Midville aquifer (eight values, model layer A3a3) and were unavailable for the Providence Sand-Peedee (model layer A3a2) and upper Atkinson-upper Tuscaloosa aquifers (model layer A4a1). Initial storativity by layer ranged from about $10^{-3}$ to $10^{-5}$, and progressively decreased seaward of the Inner Coastal Plain Margin or upgradient limit of outcrop. Initial values of storativity, as well as estimates of transmissivity based on preliminary steady-state simulations, were adjusted slightly during transient calibration in the vicinity of major cones of depression. Calibrated distributions of storativity for the five active model layers are shown in figures 33-37. A summary of calibrated storativity values by layer is given in table 13 .

Transient model simulations were calibrated against observation well hydrographs (pl. 11) and data describing 291 observed heads in 1980 (pls. 12-16, fig. 38). Actual head data used for calibration comparisons were inclusive of the period 1978-82 and were reported by Bennett and others (1983), Clarke and others (1983, 1984, 1985), Scott and others (1984), Brooks and others (1985), and Moffett and others (1985). Where wells were distant from the influences of pumping or where water levels were otherwise known to be relatively steady through time, contemporaneity of water levels was assumed, and modern head data collected several years prior to or subsequent to 1980 were considered representative of 1980 conditions. Results of the final transient calibration were evaluated statistically by comparing observed heads and simulated heads in the same manner described for the steady-state model and are summarized in table 14. Transient model calibration also was evaluated by constructing hydrographs of simulated heads and by comparing these with hydrographs of observed heads. Simulated heads used for hydrograph comparison were interpolated to the locations of observation wells by using gradients computed from simulated heads of neighboring grid cells. Ten hydrographs showing simulated, interpolated simulated, and observed heads are shown in plate 11. The locations of observation wells from which data were used to construct the hydrographs are shown in plates 12-16. Simulated heads generally are higher than observed heads because storage changes and waterlevel declines computed by the model represent an average change for a grid cell $16 \mathrm{mi}^{2}$ in area. In contrast, drawdown at observation wells generally is within an effective radius that corresponds to an area substantially smaller than $16 \mathrm{mi}^{2}$.

Locally, in upgradient areas, a small number of interpolated field data shown for 1980 indicates that a rise in water levels occurred during predevelopment to 1980 at the same grid cell. In general, these differences are small and within the contour interval of maps used to estimate the water-level altitude. Where discrepancies are large, potentiometric gradients are generally also large and may reflect interpolation from different observation points for different periods to the grid cell center.

Conversely, simulated water levels in upgradient areas at or proximate to large pumping centers may be significantly lower than interpolated observed values, even in areas of applied recharge. These discrepancies may be indicative of substantial pumping from local and intermediate flow regimes. Flow through these regimes is not simulated by the model, and in upland areas may largely consist of diversions of streamflow to wells from streams other than regional drains. Accordingly, simulated pumpage is provided mainly from storage (rather than from diverted streamflow), and corresponding simulated heads are lower than observed heads. An example of such diversions was tested for this study and is described later in relation to simulated discharges to $\mathrm{Big}$ Sandy Creek.

In downgradient areas, simulated water levels for 1980 may locally be higher than observed values where local cones of depression are substantially smaller in area than the $16 \mathrm{mi}^{2}$ represented by model nodes. A discrepancy of this type of about $90 \mathrm{ft}$ occurs in southern Randolph County in southwestern Georgia in model layer A3a1 (pls. 6, 13), where pumping from the Clayton aquifer (Clarke and others, 1984) locally has caused substantial lowering of water levels. Similarly, a discrepancy of about $80 \mathrm{ft}$ occurs in model layer A3a2 (Providence Sand-Peedee aquifer, pls. 7,14 ) in northern Barbour County, Ala., and is probably caused by pumping at the town of Clayton. In addition, field head data at these sites may be influenced by nearby local pumping and may not be representative of static conditions. 


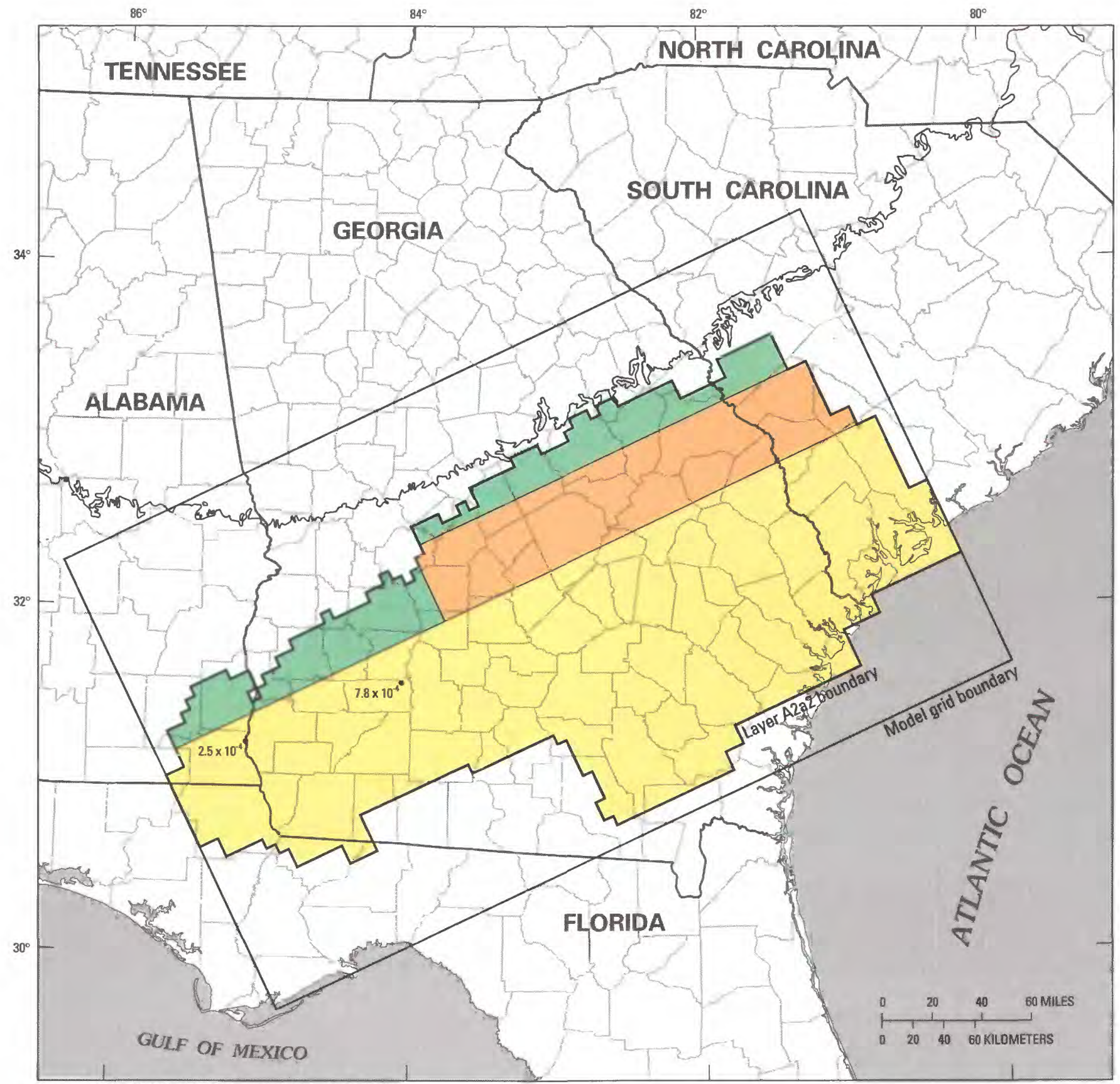

Base reduced from U.S. Geological Survey digital data, 1:2,000,000, 1972

\section{EXPLANATION}

Storativity (dimensionless)

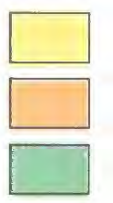
$5.2 \times 10^{-4}$
$8.2 \times 10^{-4}$
$1.2 \times 10^{-3}$ to $8.2 \times 10^{-3}$

\section{S \\ $2.5 \times 10_{0}^{-4} \quad$ Data point-Number is field storativity, in feet per foot}

FIGURE 33. - Calibrated storativity distribution for model layer A2a2 (Tallahatta-Gordon aquifer). 


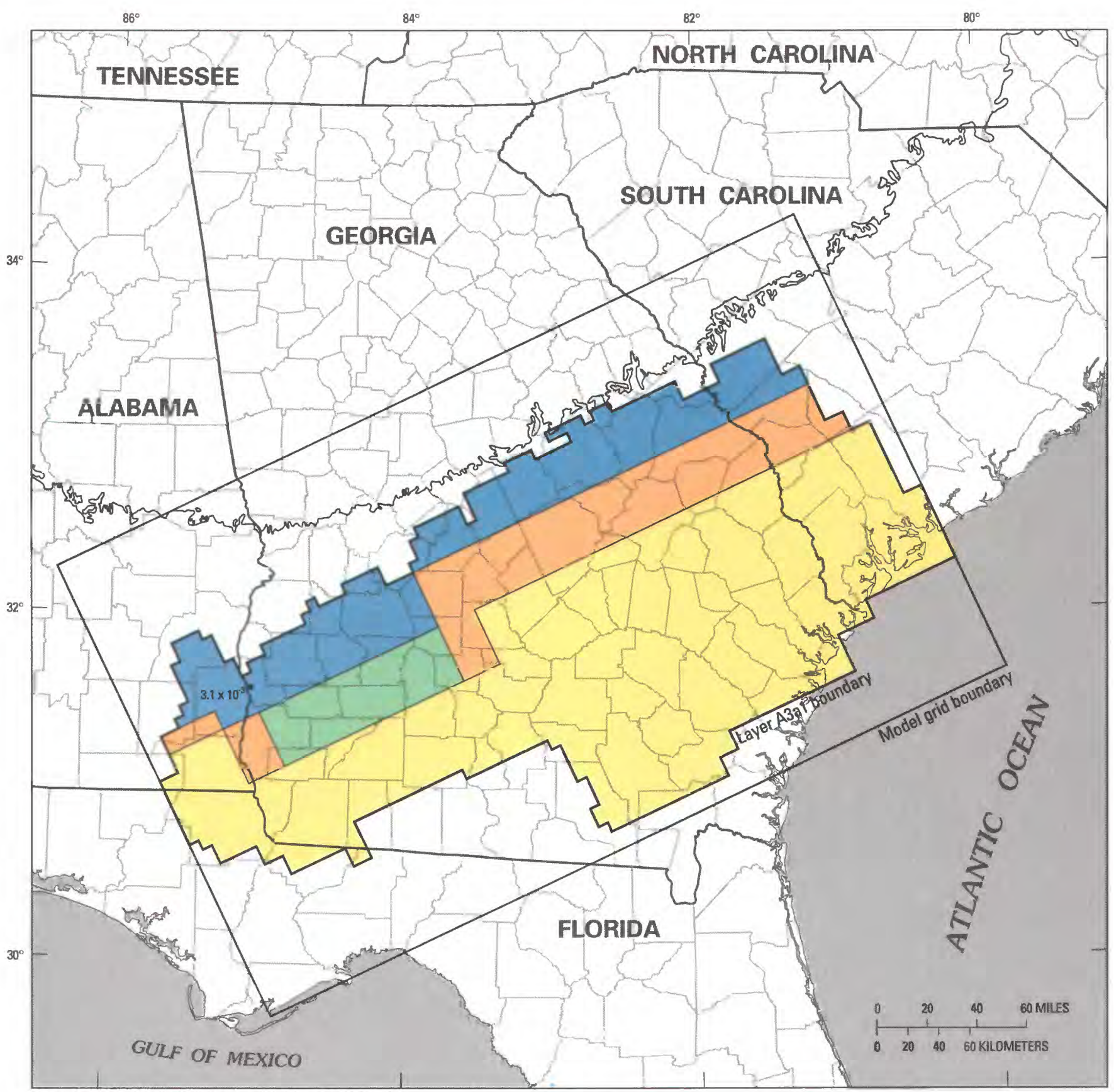

Base reduced from U.S. Geological Survey digital data, 1:2,000,000, 1972

\section{EXPLANATION}

Storativity (dimensionless)
$5.3 \times 10^{-4}$
$8.3 \times 10^{-4}$ to $9.3 \times 10^{-4}$
$2.3 \times 10^{-3}$

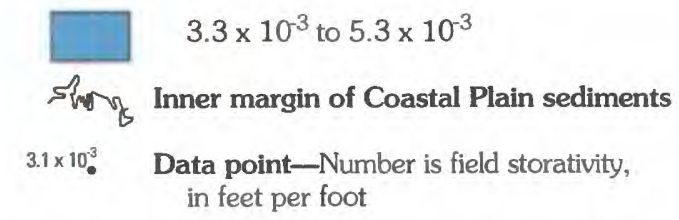

FIGURE 34.-Calibrated storativity distribution for model layer A3a1 (Clayton-Ellenton aquifer). 


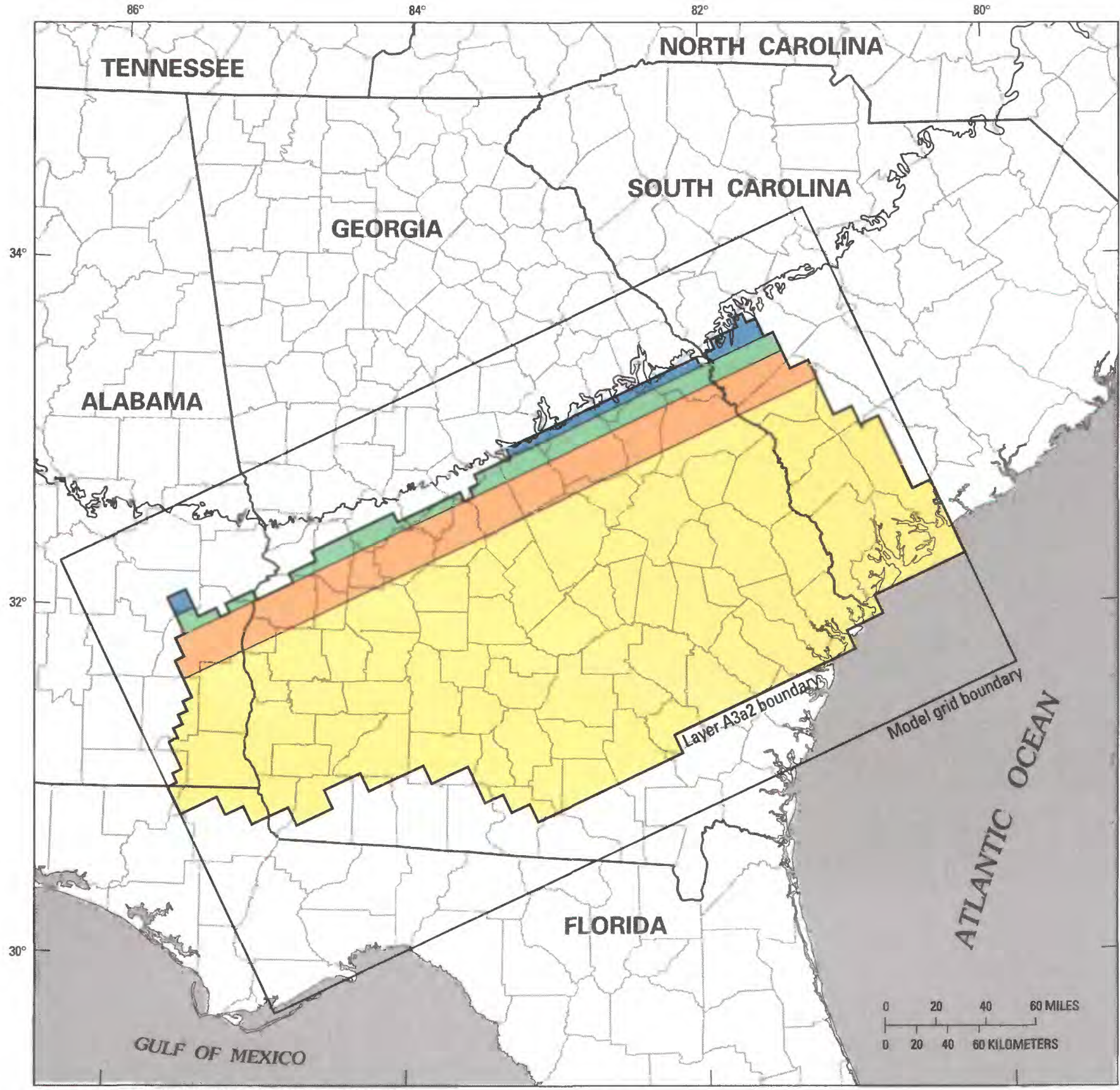

Base reduced from U.S. Geological Survey digital data, 1:2,000,000, 1972

\section{EXPLANATION}

Storativity (dimensionless)

$\begin{array}{ll}\square & 5.4 \times 10^{-4} \\ \square & 8.4 \times 10^{-4} \\ \square & 1.4 \times 10^{-3}\end{array}$

$5.4 \times 10^{-3}$

STyry Inner margin of Coastal Plain sediments

FIGURE 35.-Calibrated storativity distribution for model layer A3a2 (Providence Sand-Peedee aquifer), 


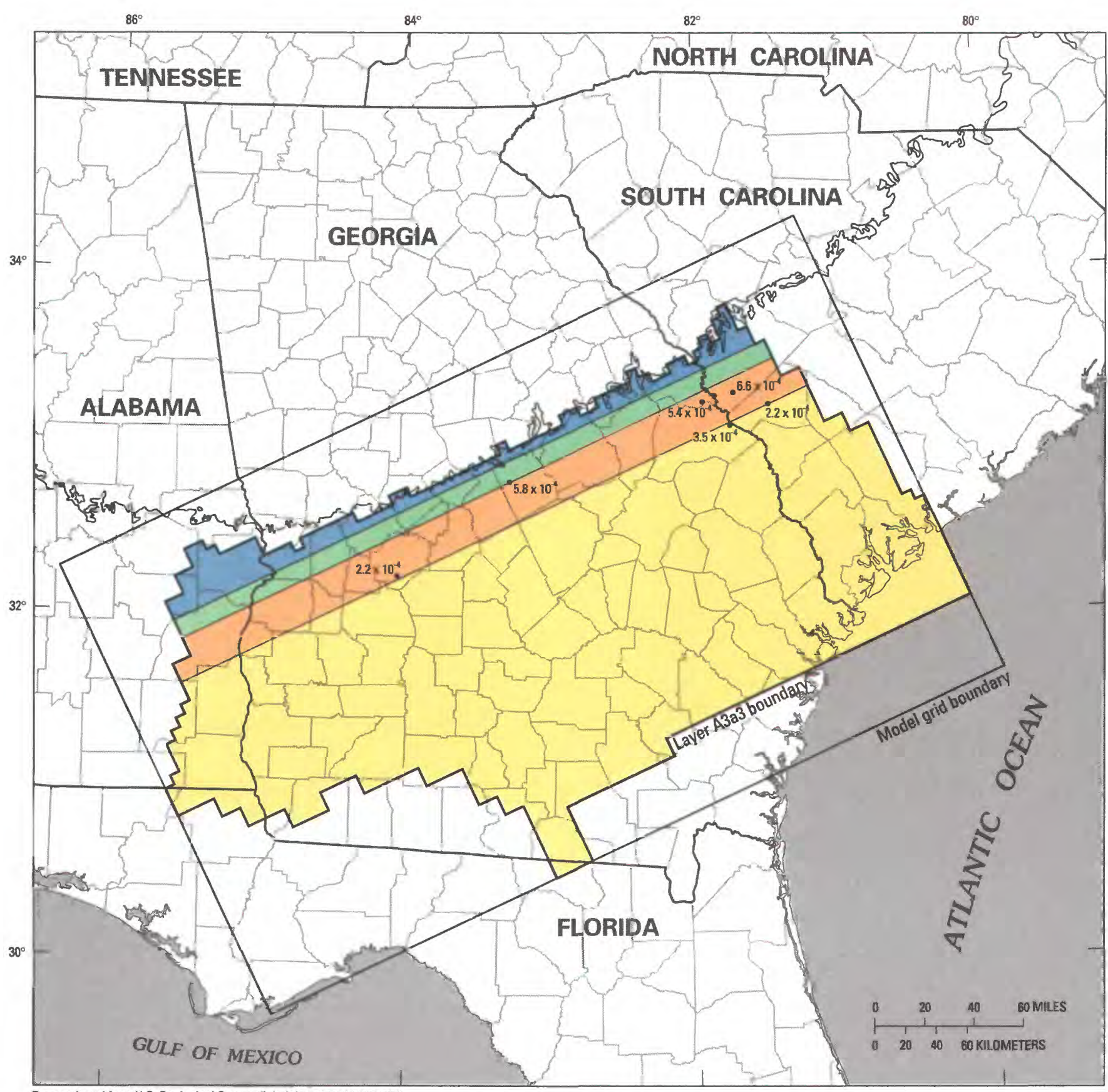

Base reduced from U.S. Geological Survey digital data, 1:2,000,000, 1972

\section{EXPLANATION}

Storativity (dimensionless)

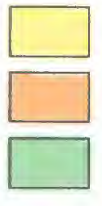

$5.5 \times 10^{-4}$

$8.5 \times 10^{-4}$

$1.5 \times 10^{-3}$

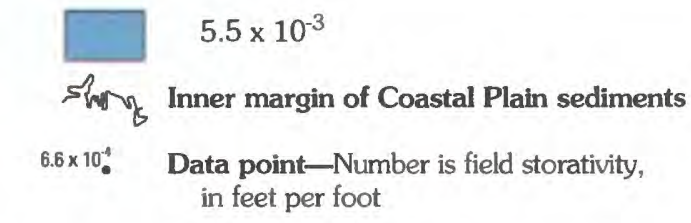

FIGURE 36. - Calibrated storativity distribution for model layer A3a3 (Eutaw-Midville aquifer). 


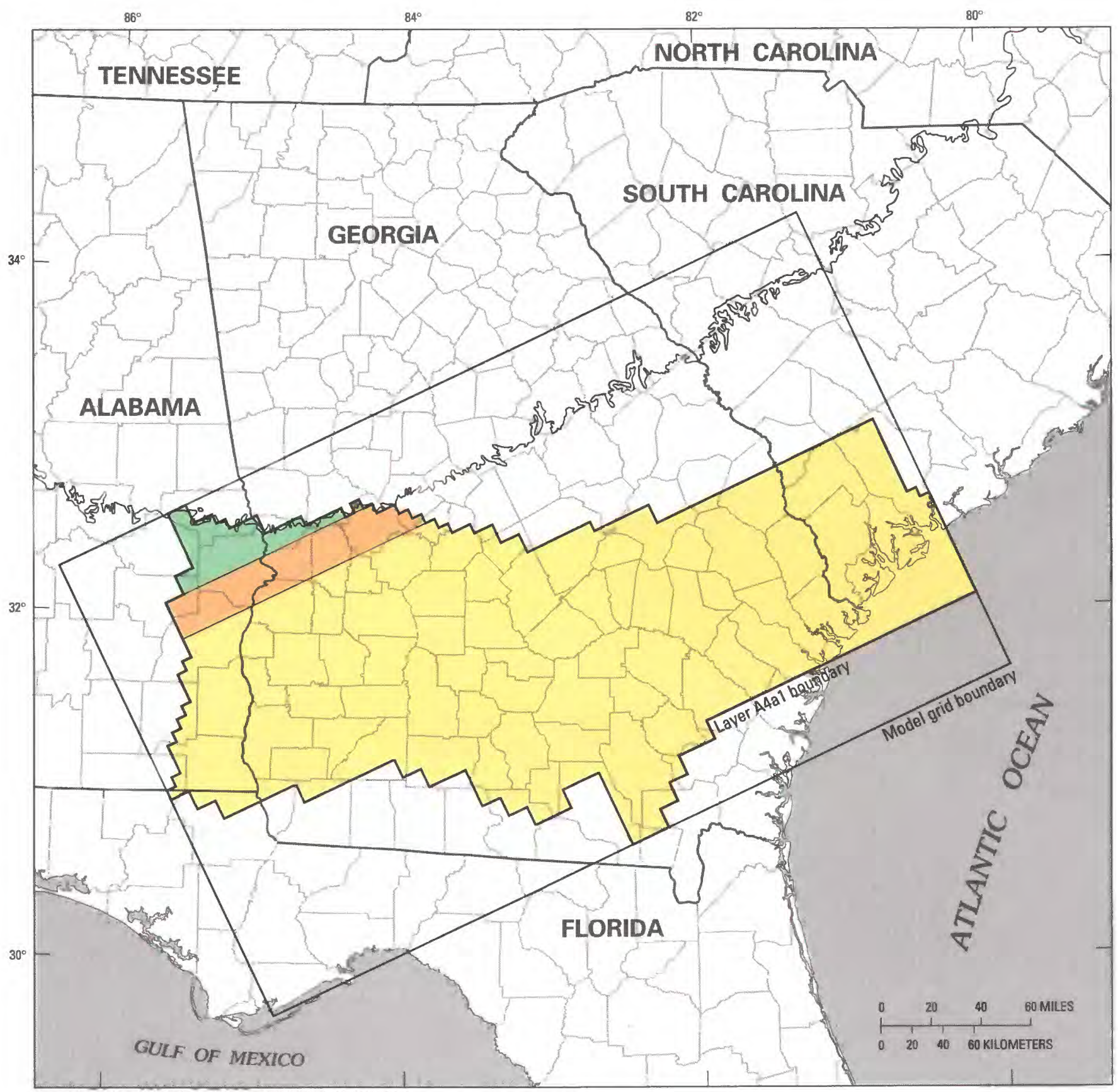

Base reduced from U.S. Geological Survey digital data, 1:2,000,000, 1972

\section{EXPLANATION}

Storativity (dimensionless)

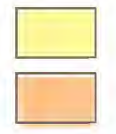

$$
\begin{aligned}
& 5.6 \times 10^{-4} \\
& 8.6 \times 10^{-4}
\end{aligned}
$$

$5.6 \times 10^{-3}$

Sfory Inner margin of Coastal Plain sediments

FIGURE 37. - Calibrated storativity distribution for model layer A4al (upper Atkinson-upper Tuscaloosa aquifer). 
TABLE 13.-Summary of calibrated storativity values

\begin{tabular}{cccc}
\hline \multirow{2}{*}{$\begin{array}{c}\text { Model } \\
\text { layer }\end{array}$} & \multicolumn{3}{c}{ Storativity values (dimensionless) } \\
\cline { 2 - 4 } & Minimum & Maximum & Mean \\
\hline A2a2 $\ldots \ldots \ldots \ldots \ldots$ & $5.2 \times 10^{-4}$ & $8.2 \times 10^{-3}$ & $4.5 \times 10^{-3}$ \\
A3a1 $\ldots \ldots \ldots \ldots \ldots$ & $5.3 \times 10^{-4}$ & $5.3 \times 10^{-3}$ & $1.6 \times 10^{-3}$ \\
A3a2 $\ldots \ldots \ldots \ldots \ldots$ & $5.4 \times 10^{-4}$ & $5.4 \times 10^{-3}$ & $8.4 \times 10^{-4}$ \\
A3a3 $\ldots \ldots \ldots \ldots \ldots$ & $5.5 \times 10^{-4}$ & $5.5 \times 10^{-3}$ & $1.3 \times 10^{-3}$ \\
A4a1 $\ldots \ldots \ldots \ldots$. & $5.6 \times 10^{-4}$ & $5.6 \times 10^{-3}$ & $1.4 \times 10^{-3}$ \\
\hline
\end{tabular}

The 1980 potentiometric surfaces (pls. $12-16$, fig. 38 ) and transient water budget (fig. 39) computed by the final calibrated model were compared with those of the steady-state model to determine the quantitative effects of pumping on subregional ground-water flow. Overall, after 80 years of simulated ground-water development, ground-water discharge to regional drains was reduced about 19 percent from predevelopment rates to about 670 $\mathrm{ft}^{3} / \mathrm{s}$ (fig. 39). Related reductions in aquifer storage of about $22 \mathrm{ft}^{3} / \mathrm{s}$ resulted in the formation of several substantial cones of depression. Simulated downward leakage from the source-sink layer increased about 27 percent over the predevelopment rate to $725 \mathrm{ft}^{3} / \mathrm{s}$. Corresponding upward leakage increased from $368 \mathrm{ft}^{3} / \mathrm{s}$ to about $430 \mathrm{ft}^{3} / \mathrm{s}$. Accordingly, downgradient discharge by 1980 equaled about $370 \mathrm{ft}^{3} / \mathrm{s}$. Horizontal flow to specified heads at model layer boundaries by 1980 had decreased from about 57 to about $19 \mathrm{ft}^{3} / \mathrm{s}$. Although budget differences are substantial between predevelopment and 1980, the general patterns and distributions of subregional ground-water flow simulated for predevelopment conditions were altered only slightly in most aquifers by 1980 .

Simulated water-level declines for the period January 1900 to December 1980 are shown by model layer in figures 40-44.

For model layer A2a2, transient flow simulations ending in December 1980 resulted in a total reduction in aquifer discharge to streams and to regional drains of about 10 percent from simulated predevelopment rates. Downward leakage from the source-sink layer A2a1 increased approximately 23 percent from predevelopment rates, and downward leakage to layer A3a1 increased by about 350 percent (fig. 39). Subregional ground-water flow was most affected in the vicinity of Savannah, Ga., where upward leakage to layer A2a1, which represents the heavily pumped Upper Floridan aquifer in southeastern and coastal Georgia (Krause and Randolph, 1989), increased an order of magnitude over predevelopment rates. Maximum simulated water-level declines near Savannah, Ga., were in excess of $100 \mathrm{ft}$ in model layer A2a2. Ground-water pumping in Dougherty, Twiggs, Wilkinson, and Laurens Counties, Ga., and in
Aiken County, S.C., produced local, relatively minor water-level changes that were generally $25 \mathrm{ft}$ or less (pl. 12, fig. 40).

Transient model simulations of pumping from model layer A3a1 indicated that discharge to the regional drains decreased about 21 percent from rates simulated by the steady-state model. Net leakage across the underlying confining unit, A3c1, reversed from about $63 \mathrm{ft}^{3} / \mathrm{s}$ upward in the steady-state model (fig. 32) to $37 \mathrm{ft}^{3} / \mathrm{s}$ downward in the transient model (fig. 39). A large area of simulated water-level declines is shown in parts of Dougherty, Early, Randolph, Terrell, Webster, and Sumter Counties, Ga. (pl. 13, fig. 41). These declines in southwestern Georgia reflect pumping from the Clayton aquifer for irrigation and municipal purposes (Clarke and others, 1984). Maximum simulated water-level declines near Albany, Ga., are in excess of $200 \mathrm{ft}$. The steep hydraulic gradient east of Albany is the result of the relatively low transmissivities of the aquifer in that area (fig. 23). In nearby Houston County, Ala., a smaller area of simulated water-level declines is the result of groundwater pumping from the Clayton aquifer in the vicinity of Dothan, Ala. A comparison of the predevelopment and 1980 simulated potentiometric maps (pls. 6, 13) indicates that pumping from these areas altered the direction of downgradient flow in the western part of the subregion, turning it slightly southwestward; under predevelopment conditions, flow generally was due south. In Hampton County in western South Carolina, a small area of simulated water-level declines occurred in the vicinity of Hampton and Varneville. Simulated ground-water pumping in Twiggs County, Ga., also produced a small area of water-level declines (fig. 41). Simulated pumping in Houston and Laurens Counties, Ga., produced only local water-level declines (fig. 41).

Simulated pumping from model layer A3a2 resulted in a decrease in discharge to regional drains from simulated predevelopment conditions of about 28 percent (figs. 32 , 39). Downward leakage to layer A3a3 increased from about $8 \mathrm{ft}^{3} / \mathrm{s}$ to about $30 \mathrm{ft}^{3} / \mathrm{s}$ by 1980 . Two major areas and one minor area of water-level declines are shown in plate 13 and figure 41 . A maximum, simulated decline of about $200 \mathrm{ft}$ occurred in the vicinity of Albany, Ga., largely in response to upward leakage to overlying layer A3al. Another area of major decline occurred in Allendale and Barnwell Counties, S.C., largely as a result of pumping at the Savannah River Plant and at the city of Allendale. A less extensive area of decline, shown in Twiggs County, Ga., probably is the result of pumping related to the mining and processing of kaolin. Substantial ground-water pumping in Houston, Wilkinson, and Washington Counties, Ga., produced only minor, local declines in water levels, $25 \mathrm{ft}$ or less. Although pumping rates are relatively high in these areas, the small declines 


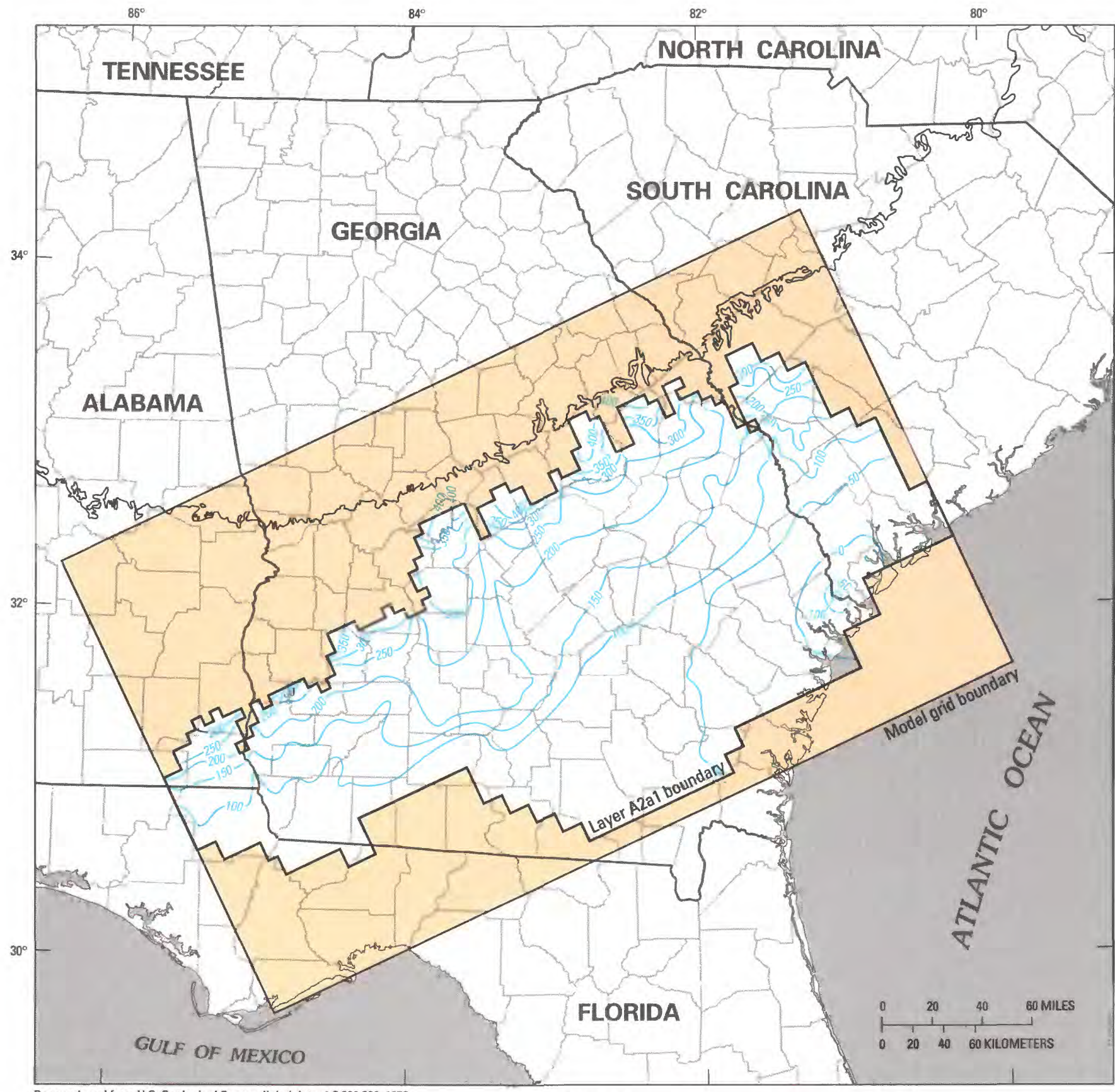

Base reduced from U.S. Geological Survey digital data, 1:2,000,000, 1972

\section{EXPLANATION}

Inactive nodes

Potentiometric contour-Shows altitude at which water level would have stood in tightly cased wells. Contour interval 50 feet. Datum is sea level

Shutn Inner margin of Coastal Plain sediments

FigURE 38. - Potentiometric surface of specified-head, source-sink model layer A2a1 (Barnwell-Upper Floridan aquifer), 1980. 
TABLE 14. - Summary of statistical evaluations of the simulated 1980 potentiometric surfaces

\begin{tabular}{|c|c|c|c|c|c|c|}
\hline \multirow{2}{*}{$\begin{array}{l}\text { Model } \\
\text { layer }\end{array}$} & \multirow{2}{*}{$\begin{array}{l}\text { Number of } \\
\text { residuals }\end{array}$} & \multicolumn{3}{|c|}{ Residual quartile (feet) } & \multirow{2}{*}{$\begin{array}{l}\text { Number of } \\
\text { residuals } \\
\text { less than or } \\
\text { equal to } 15 \text { feet }\end{array}$} & \multirow{2}{*}{$\begin{array}{l}\text { Root mean } \\
\text { square } \\
\text { error } \\
\text { (feet) }\end{array}$} \\
\hline & & First & Second & Third & & \\
\hline $\mathrm{A} 2 \mathrm{a} 2 \ldots \ldots \ldots \ldots$ & 108 & 6.0 & 13.0 & 23.0 & 65 & 23.6 \\
\hline $\mathrm{A} 3 \mathrm{a} 1 \ldots \ldots \ldots \ldots$ & 55 & 10.0 & 18.0 & 28.0 & 24 & 29.8 \\
\hline $\mathrm{A} 3 \mathrm{a} 2 \ldots \ldots \ldots \ldots$ & 42 & 8.0 & 15.0 & 34.0 & 21 & 32.5 \\
\hline A3a3 ............ & 76 & 9.0 & 16.0 & 27.0 & 36 & 30.0 \\
\hline A4a1 $\ldots \ldots \ldots \ldots$ & 10 & 8.0 & 27.0 & 40.0 & 4 & 33.0 \\
\hline All layers ......... & 291 & 8.0 & 15.0 & 28.0 & 150 & 28.2 \\
\hline
\end{tabular}

probably are the result of both relatively high transmissivities and the proximity of pumping to recharge areas. A comparison of 1980 and predevelopment potentiometric surfaces (pls. 7,14 ) indicates that subregional flow directions in the western part of the study area were altered from a southerly direction prior to development to a direction toward the major pumping center at Albany, Ga., by 1980 .

Simulated discharge to regional drains from layer A3a3 at the end of transient model simulations equaled about 77 percent of simulated predevelopment discharge (figs. 32, 39). Upward leakage from layer A4al increased from about $1.3 \mathrm{ft}^{3} / \mathrm{s}$ prior to development to about 2.3 $\mathrm{ft}^{3} / \mathrm{s}$ by December 1980 . In layer $\mathrm{A} 3 \mathrm{a} 3$, the areas of greatest ground-water pumping are just south of the Inner Margin of Coastal Plain sediments in central and eastern Georgia and in western South Carolina (pl. 10). Simulated pumping rates in these areas are relatively high; however, the high transmissivity of the aquifer, especially in Barnwell County, S.C., and the proximity

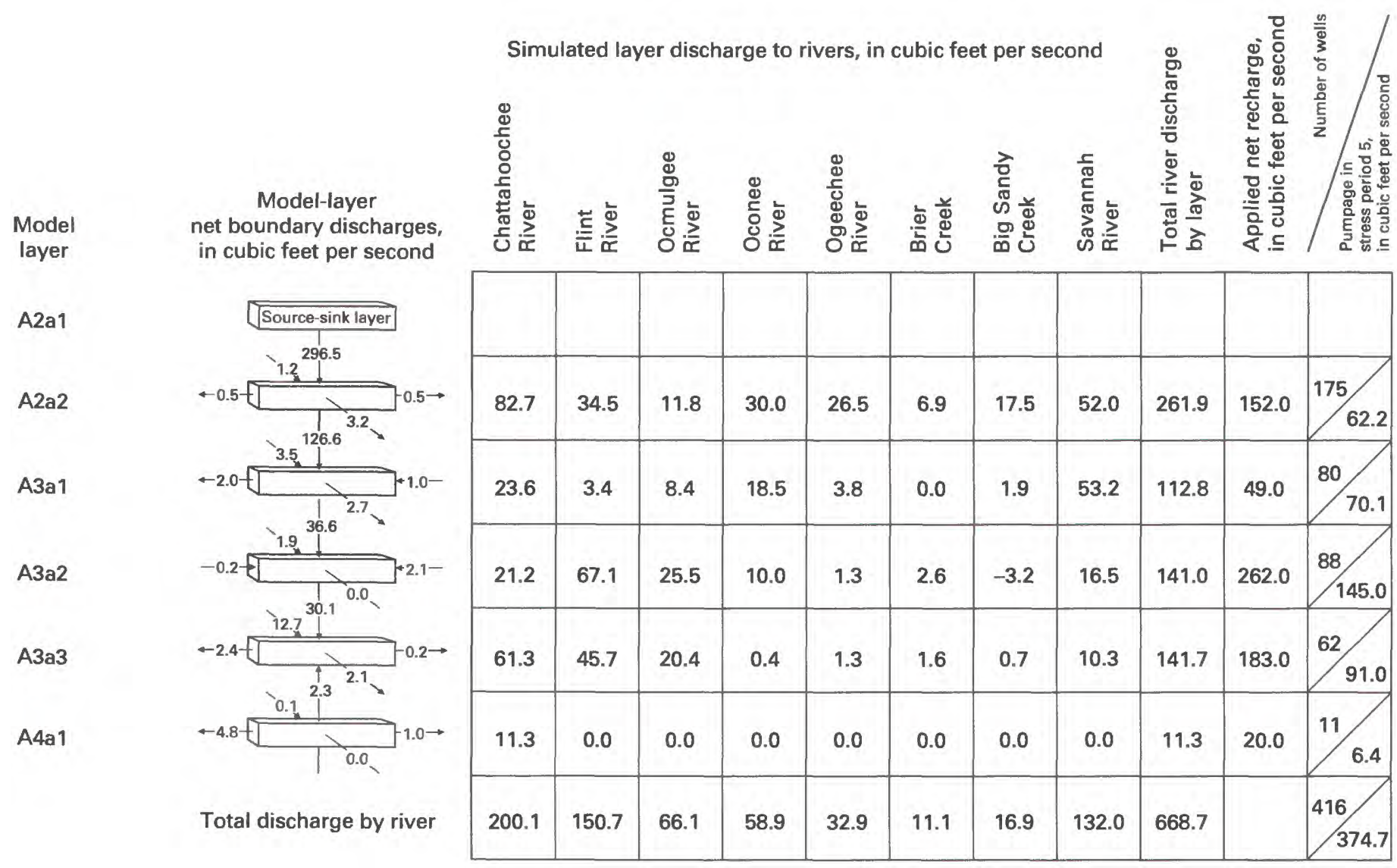

FIGURE 39. - Simulated components of the 1980 water budget, by model layer. 


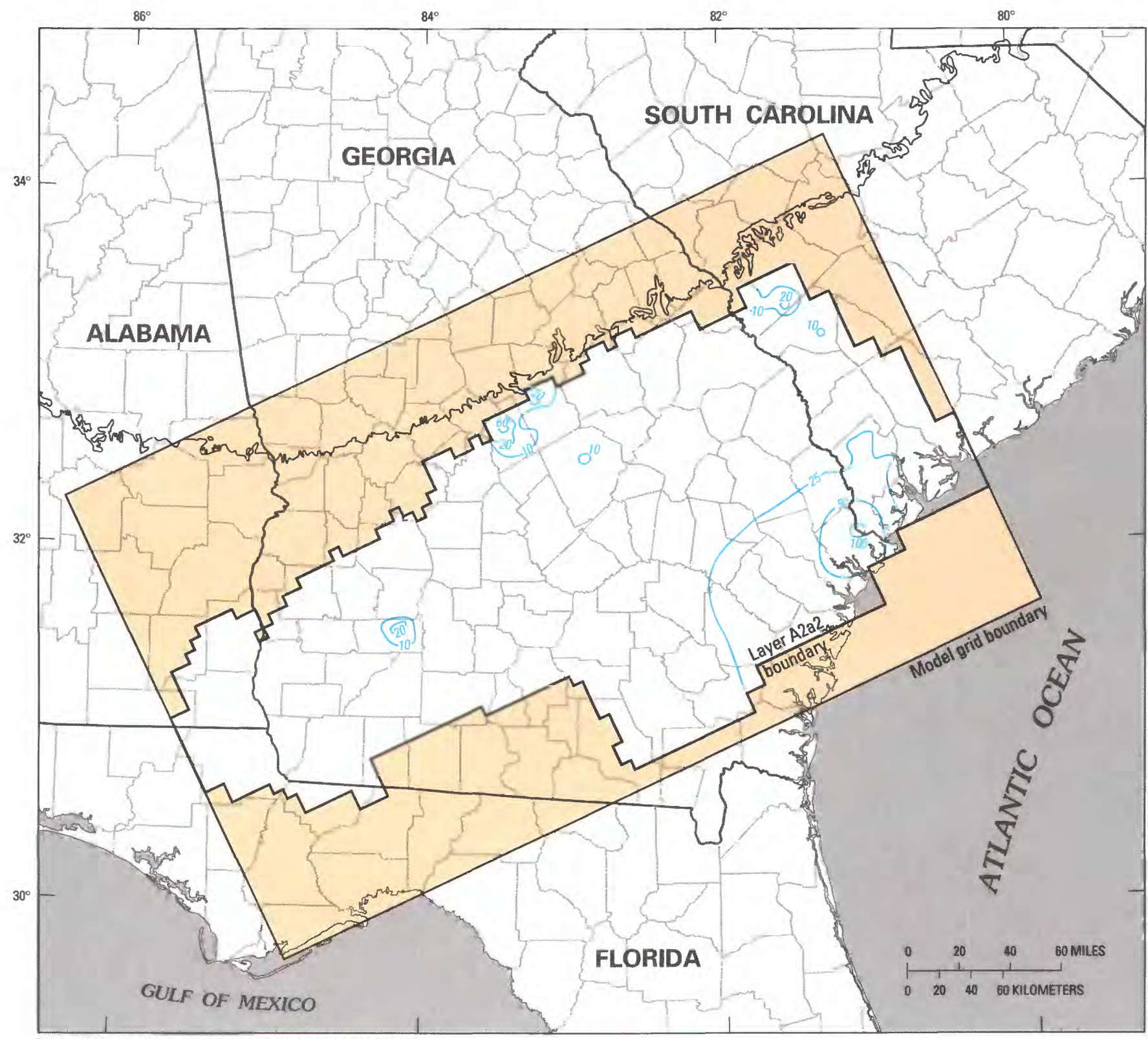

Base reduced from U.S. Geological Survey digital data, 1:2,000,000, 1972

\section{EXPLANATION}

Inactive nodes

- 10- Line of equal water-level decline-Shows amount of decline of water level. Interval, in feet, is variable

Shorn Inner margin of Coastal Plain sediments

FIGURE 40. - Simulated water-level decline for model layer A2a2 (Tallahatta-Gordon aquifer), January 1900 to December 1980.

to recharge areas resulted in only small areas of minor water-level declines (fig. 43). A comparison of simulated, predevelopment, and 1980 potentiometric surfaces for layer A3a3 (pls. 8, 15) indicates that a general head decline occurs in areas south of major pumping centers. This is best illustrated by the change in the position of the $250-\mathrm{ft}$ and $300-\mathrm{ft}$ potentiometric contours in central and west-central Georgia. In Barnwell County, S.C., the 


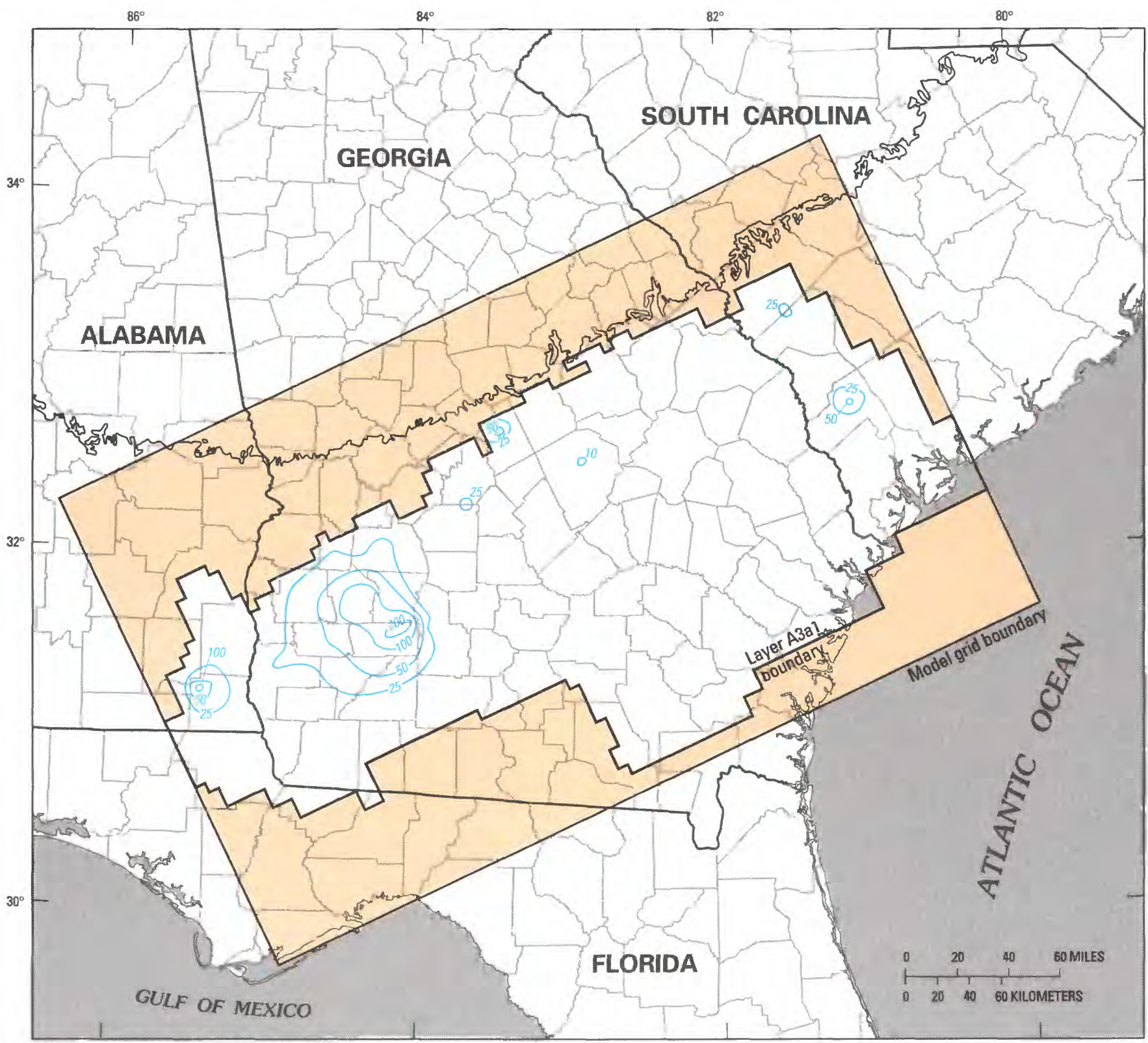

Base reduced from U.S. Geological Survey digital data, 1:2,000,000, 1972

\section{EXPLANATION}

Inactive nodes

- 50 - Line of equal water-level decline-Shows amount of decline of water level. Interval, in feet, is variable

Shorn Inner margin of Coastal Plain sediments

FIGURE 41. - Simulated water-level decline for model layer A3al (Clayton-Ellenton aquifer), January 1900 to December 1980.

noticeable curvature of the 200-ft contour in December 1980 (pl. 15) is the result of ground-water pumping near Snelling, which is near the center of the county.

The simulated pumping in layer A4a1 was minor and had little or no effect on discharge to regional drains when compared with predevelopment conditions (figs. 32 , 39). Substantial ground-water pumping was simulated in Barbour County, Ala., which resulted in a small area of water-level declines near the city of Eufaula (fig. 44). The pumping slightly affected subregional ground- 


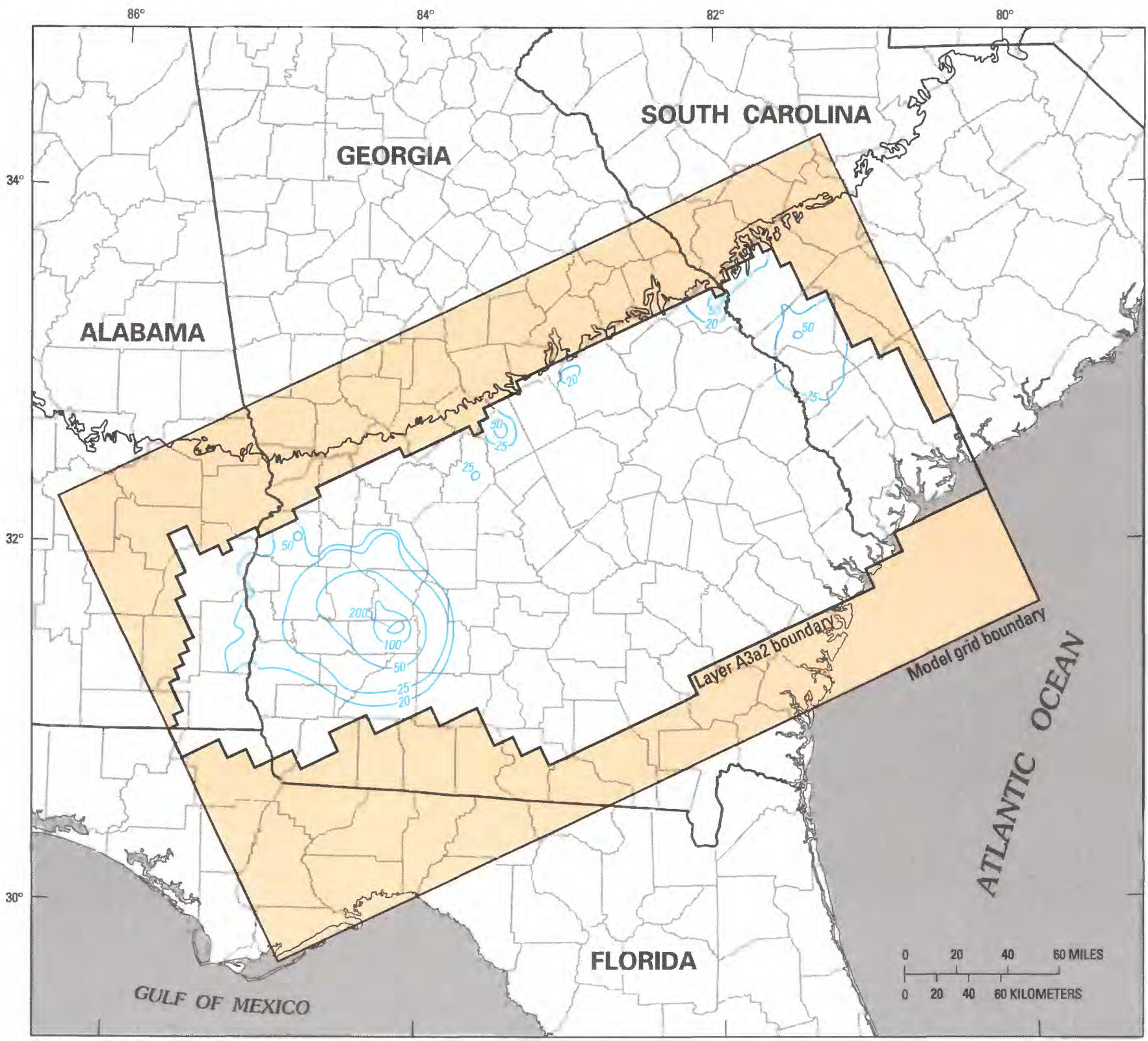

Base reduced from U.S. Geological Survey digital data, 1:2,000,000, 1972

\section{EXPLANATION}

Inactive nodes

Line of equal water-level decline-Shows amount of decline of water level. Interval, in feet, is variable

SAvon Inner margin of Coastal Plain sediments

FIGURE 42. - Simulated water-level decline for model layer A3a2 (Providence Sand-Peedee aquifer), January 1900 to December 1980.

water flow, as shown by a comparison of the 250 -ft contours in the western part of the study area for conditions prior to development and for 1980 (pls. 9, 16). Other minor ground-water pumping at Georgetown in Quitman County, Ga., and in Chattahoochee and Macon
Counties, Ga., produced local water-level declines of $25 \mathrm{ft}$ or less.

Simulated discharge to Big Sandy Creek is considered representative of discharge from local and intermediate flow regimes to streams in the northern part of the 


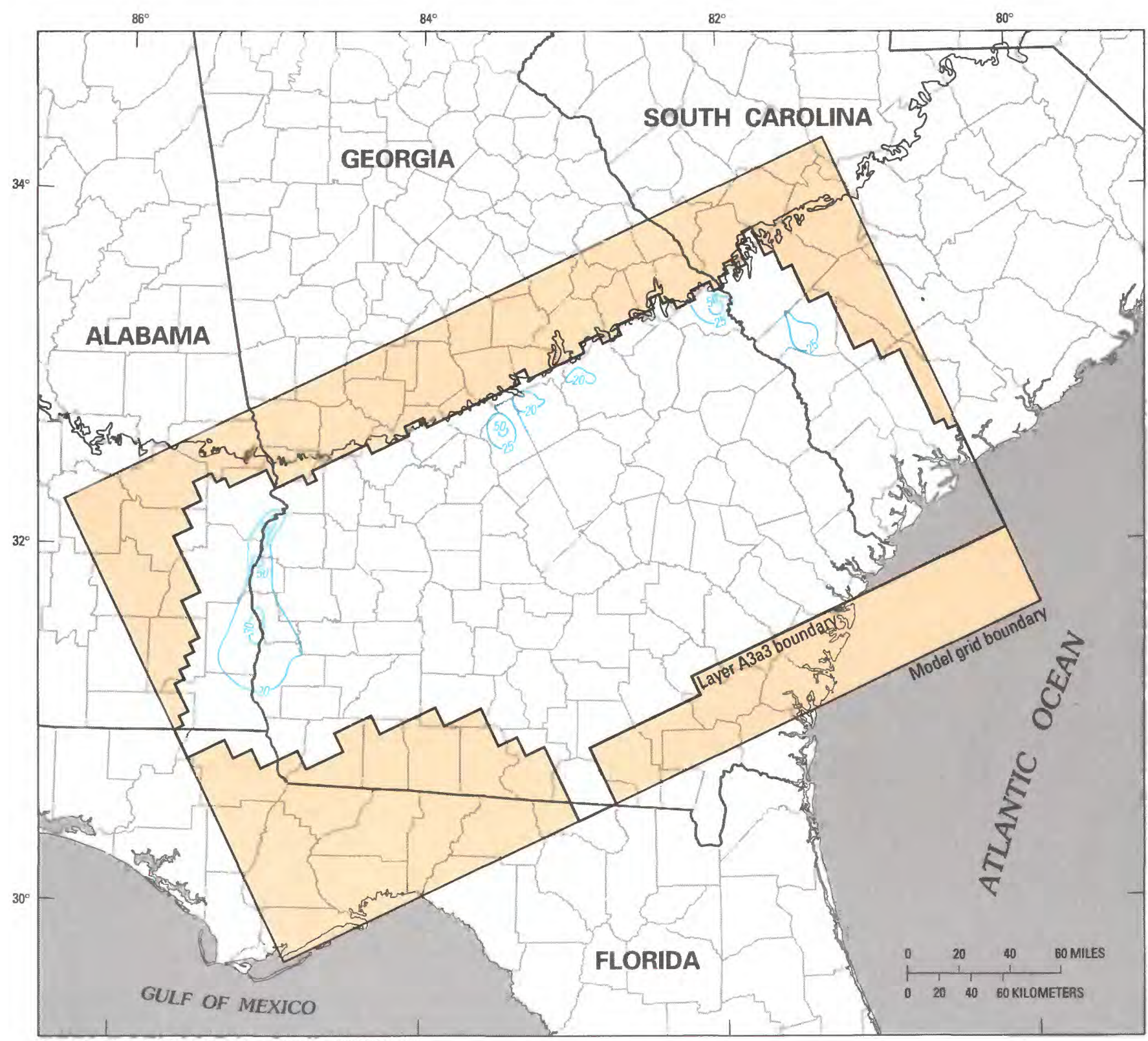

Base reduced from U.S. Geological Survey digital data, 1:2,000,000, 1972

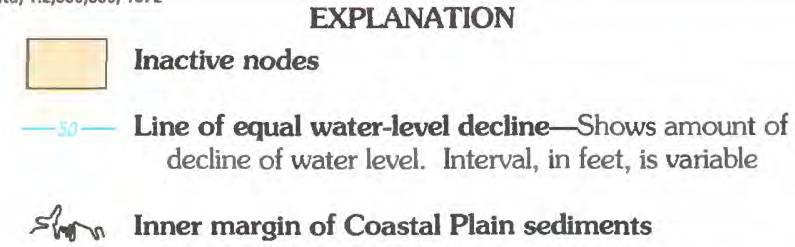

Figure 43. - Simulated water-level decline for model layer A3a3 (Eutaw-Midville aquifer), January 1900 to December 1980.

subregion. As such, transient model simulations of substantial ground-water pumping near Big Sandy Creek may serve as a general example of stream-aquifer response to ground-water resource development in and near areas of outcrop of subregional aquifers. Combined discharge to Big Sandy Creek from all model layers during simulated predevelopment conditions was $44 \mathrm{ft}^{3} / \mathrm{s}$ (fig. 32). Corresponding aquifer discharges at the end of transient model simulations totaled about $17 \mathrm{ft}^{3} / \mathrm{s}$ (fig. 39). Reductions in simulated discharge were noted for 


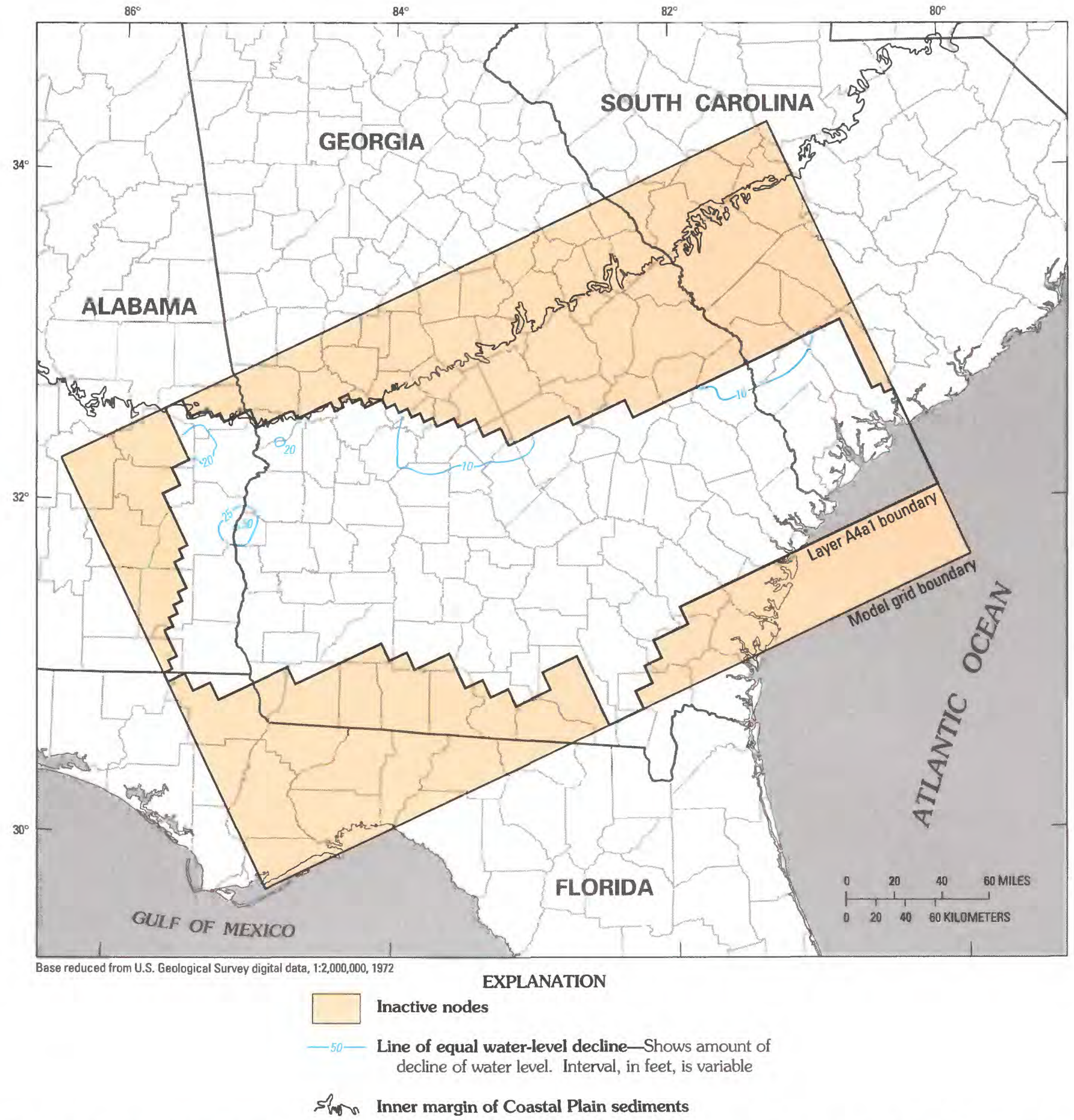

FIGURE 44 - Simulated water-level decline for model layer A4a1 (upper Atkinson-upper Tuscaloosa aquifer), January 1900 to December 1980.

every model layer related to Big Sandy Creek and were substantial for model layers A2a2 (about 26 to $18 \mathrm{ft}^{3} / \mathrm{s}$ ) and $\mathrm{A} 3 \mathrm{a} 2$ (about 10 to $-3 \mathrm{ft}^{3} / \mathrm{s}$ ). Simulated pumping from these layers in the vicinity of Big Sandy Creek was relatively great during the last three stress periods and apparently intercepted flow that originally discharged to the creek as well as flow from the creek itself. Similar stream-aquifer interactions probably will occur else- 
TABLE 15.-Summary of sensitivity analyses of transient model simulations

$[-$, up; + , down $]$

\begin{tabular}{lccccc}
\hline & $\begin{array}{c}\text { Root mean } \\
\text { square } \\
\text { error } \\
\text { (feet) }\end{array}$ & $\begin{array}{c}\text { Total river } \\
\text { discharge } \\
\text { (cubic feet } \\
\text { per second) }\end{array}$ & $\begin{array}{c}\text { Net vertical } \\
\text { leakage } \\
\text { (cubic feet } \\
\text { per second) }\end{array}$ & $\begin{array}{c}\text { Net horizontal boundary } \\
\text { discharge from model } \\
\text { (cubic feet } \\
\text { per second) }\end{array}$ \\
\hline Calibrated ......... & Factor & 28.2 & 672 & +487 & +4.4 \\
Storage coefficient .... & 1.0 & 32.2 & 658 & +513 & +6.8 \\
Storage coefficient .... & 2.0 & 31.6 & 701 & +453 & +.1 \\
Storage coefficient.... & 10.0 & 39.3 & 743 & +363 & -8.6 \\
\hline
\end{tabular}

where in areas of outcrop of subregional aquifers in response to substantial ground-water resource development.

Comparisons of simulated and observed water levels in four model layers are shown in plate 11 in the form of hydrographs at 10 observation wells. The length of record represented by the hydrographs is variable and ranges from about 2 to 30 years. In addition, field observations were made at irregular intervals in time at most sites. Regardless, the quality of hydrograph simulations generally is good, and computed water levels match field heads within $20 \mathrm{ft}$ or less at most sites. These simulations generally conform to and complement the areal representations of potentiometric surfaces described previously (pls. 12-16, fig. 38).

\section{SENSITIVITY ANALYSIS OF TRANSIENT MODEL}

The sensitivity of the transient model was evaluated by adjusting storativity by factors of $0.5,2.0$, and 10.0 (table 15). Other model data matrices remained unchanged from the final calibrated values. Root mean square errors were computed using 291 comparisons of simulated with interpolated field heads. The results of the sensitivity analysis indicate that the model results are less sensitive to changes in storativity than to corresponding changes in transmissivity and recharge (table 15). With a reduction in storativity to one-half of calibrated values, less water was released from storage per unit volume of aquifer than during corresponding calibrated simulations, and simulated heads were lowered throughout the model. Total river discharge was slightly decreased. The greatest declines occurred near areas of pumping, where the reduced storage coefficients resulted in greater drawdowns and slightly larger cones of depression than those simulated using calibrated storativity values. Almost all of the increase in downward net vertical leakage indicated in table 15 was from the specified-head layer (A2a1). Simulated doubling of storativity allowed more water to be removed from storage per unit volume of aquifer in comparison with simulations using calibrated storativity values. This doubling slightly raised simulated heads, increased total river discharge, and reduced net vertical downward leakage from layer A2a1 slightly below the calibrated value. Near areas of pumping, the simulated heads were higher than the calibrated heads, but elsewhere, heads generally were unchanged. Increasing storativity by a factor of 10.0 produced a somewhat exaggerated but similar response to that produced by doubling storativity.

\section{LINKAGE WITH FLORIDAN REGIONAL AQUIFER-SYSTEM} ANALYSIS MODELS

The Georgia subregion digital ground-water flow model was linked with two previously calibrated Floridan RASA models: a ground-water flow model of the Upper Floridan aquifer in the Dougherty Plain and adjacent areas of southwestern Georgia and southeastern Alabama (Maslia and Hayes, 1988), and a model of the Upper and Lower Floridan aquifers in eastern Georgia and southwestern South Carolina (Krause and Randolph, 1989). The common areas of the Georgia subregion model and the Floridan aquifer models are shown in figure 45. The model of flow in the Upper Floridan aquifer of the Dougherty Plain and adjacent areas was linked to the Georgia subregion model by simulating leakage to and from the Barnwell-Upper Floridan aquifer (source-sink model layer A2a1) through the LisbonMcBean confining unit (model layerA2c1). Linkage with the eastern part of the Floridan aquifer was accomplished by simulating leakage through the TuscahomaFishburne confining unit (model layer C2) into the Lower Floridan aquifer, which is generally equivalent to the Tallahatta-Gordon aquifer (model layerA2a2) of this report, seaward of the Gulf trough. In both cases, the Floridan aquifer models were calibrated by using the top of these respective confining units (layers A2c1 and C2) as no-flow boundaries (Maslia and Hayes, 1988; Krause and Randolph, 1989). Accordingly, appropriate linkage with the Georgia subregion model required that simulated, net vertical leakage across these confining units be small with respect to total simulated flow through the respective units of the Floridan aquifer. Comparisons were made only for the predevelopment (steady-state) condition. 


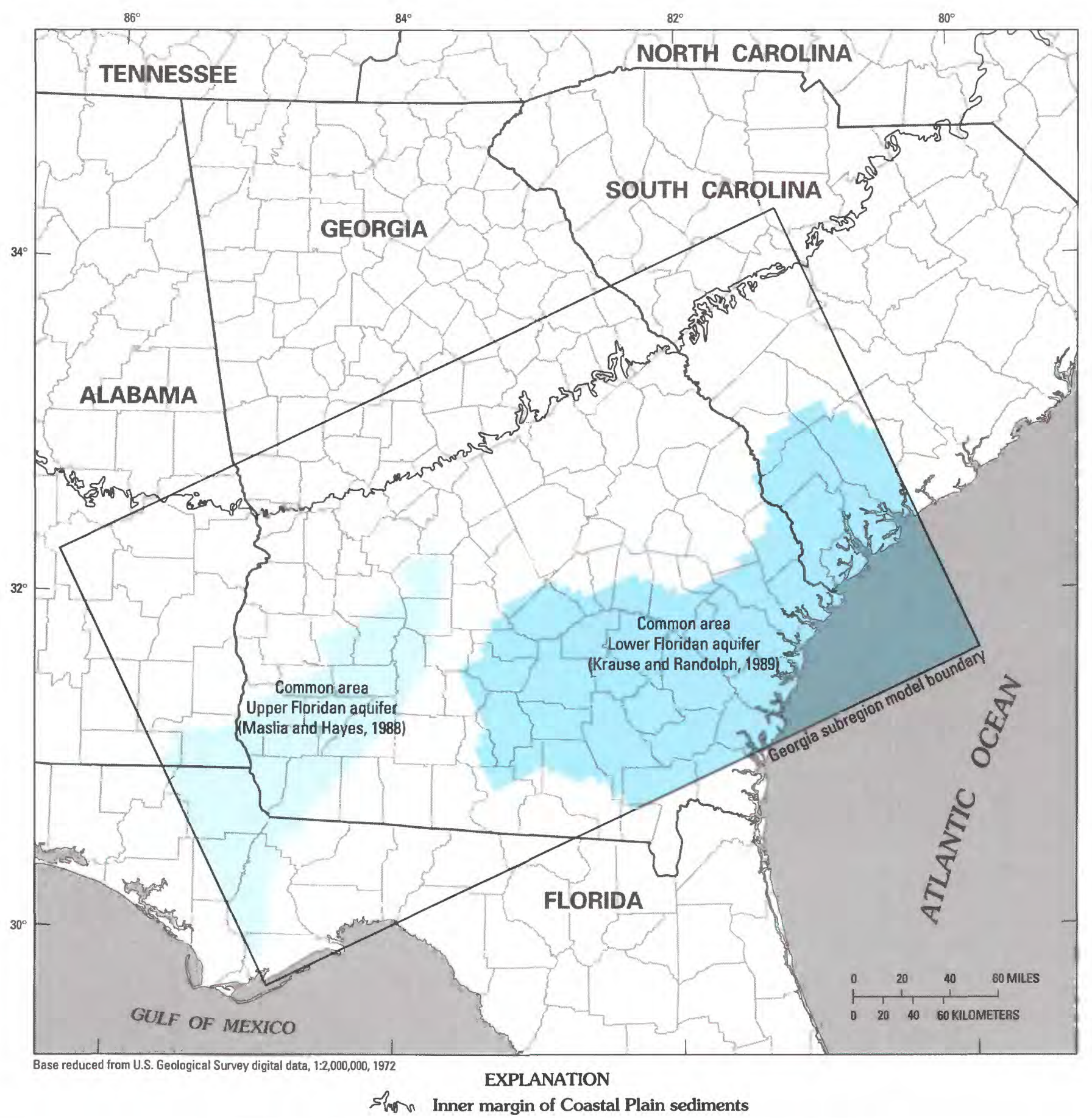

FIGURE 45. - Areas common to Floridan Regional Aquifer-System Analysis models.

Additional correspondence between the flow simulated within the Tallahatta-Gordon aquifer (model layer A2a2) of this report and the Lower Floridan aquifer of Krause and Randolph (1989) was accomplished by using identical distributions of transmissivity within the common area, southeast of the Gulf trough (R.E. Krause, U.S. Geological Survey, written commun., 1984) (figs. 1, 22).
Simulated, predevelopment leakage to the Upper Floridan aquifer across the Lisbon-McBean confining unit within the common area in the southwestern part of the Georgia subregion was about $10 \mathrm{ft}^{3} / \mathrm{s}$. Simulated recharge to the Tallahatta-Gordon aquifer was about $5 \mathrm{ft}^{3} / \mathrm{s}$. Total steady-state simulated flow through the Upper Floridan aquifer within this common area was 
about 4,000 $\mathrm{ft}^{3} / \mathrm{s}$ (Maslia and Hayes, 1988). Similarly, simulated predevelopment leakage to the Lower Floridan aquifer across the Tuscahoma-Fishburne confining unit within the common area in the southeastern part of the Georgia subregion was about $3 \mathrm{ft}^{3} / \mathrm{s}$. Total simulated flow through this part of the Lower Floridan aquifer was about $34 \mathrm{ft}^{3} / \mathrm{s}$ (Krause and Randolph, 1989). Thus, leakage rates simulated by the Georgia subregion RASA model apparently are small or within a reasonable error relative to simulated flow through overlying units of the Floridan aquifer system, and support the concept of no-flow boundaries at the base of the Floridan RASA models.

\section{SUMMARY AND CONCLUSIONS}

Ground-water flow in five areally extensive, generally clastic aquifers of the Georgia subregion, Southeastern Coastal Plain RASA, was simulated by using a digital, finite-difference model that accounts for horizontal flow in multiple, vertically contiguous aquifers and vertical leakage through intervening confining units. Aquifers investigated are part of a regionally extensive aquifer system composed largely of unconsolidated sediments ranging in age from early Tertiary through Late Cretaceous that extend from eastern South Carolina to Mississippi. Ground-water flow was simulated in the Tallahatta-Gordon, Clayton-Ellenton, Providence SandPeedee, Eutaw-Midville, and upper Atkinson-upper Tuscaloosa aquifers. The uppermost layer of the model was a source-sink layer and represented the BarnwellUpper Floridan aquifer. Intervening confining units were designated, respectively, the Lisbon-McBean, Tuscahoma-Fishburne, Providence Sand-Peedee, Ripley-Black Creek, and Eutaw-Cape Fear.

Areas of outcrop and recharge for Georgia subregional aquifers occur throughout the northern part of the Coastal Plain, typically extending west to east in zones ranging in width from about 5 to $15 \mathrm{mi}$. These areas are highly dissected by streams, which, depending on location and degree of channel incisement, are lines of discharge for one or more subregional aquifers. Groundwater flow within outcrop and adjacent areas is controlled by topography and by the location and extent of ground-water discharge to streams. Potentiometric surfaces of subregional aquifers in outcrop areas resemble subdued replicas of surface topography. Ground-water flow in this part of the subregion can be described in terms of local, intermediate, and regional flow regimes. Discharge from the regional flow regime probably occurs only to major Coastal Plain streams such as the Chattahoochee, Flint, Ocmulgee, Oconee, Ogeechee, and Savannah Rivers (regional drains). Mean annual dis- charge to these streams was of primary importance to this study as a standard for flow model calibration and was estimated to be $780 \mathrm{ft}^{3} / \mathrm{s}$, based on analyses of drought streamflow data and stream hydrograph separations. Subsurface discharge downgradient from outcrop areas was estimated to be $310 \mathrm{ft}^{3} / \mathrm{s}$ and also was used as a calibration standard.

Maximum dimensions of the grid used for the digital flow model were 50 rows and 82 columns. The actual number of active grid cells per layer was variable and dependent on the areal distribution of individual subregional aquifers. Grid size was constant and equaled $4 \mathrm{mi}$ per side, representing an area of $16 \mathrm{mi}^{2}$.

The Barnwell-Upper Floridan aquifer is the uppermost model layer and was simulated as a source-sink layer. Rocks at the base of Coastal Plain sediments or at the top of the middle Atkinson confining unit generally represented the base of the model. Lateral model boundaries generally coincided with the drainage divide of the Chattahoochee River in Alabama and the corresponding divide of the Savannah River in South Carolina. Lateral boundaries were simulated as specified head or no flow. The downgradient boundary in each layer was simulated as no flow near the seaward extent of freshwater. The southwestern downgradient boundary of the TallahattaGordon aquifer was simulated by specified heads. Steady-state (predevelopment) recharge to the model was applied in respective aquifer outcrop areas at rates ranging from about 0.01 to $9 \mathrm{in} / \mathrm{yr}$, the higher rates generally occurring along the major divides between regional drains. Mean annual recharge was about $1 \mathrm{in} / \mathrm{yr}$. The total mean annual rate of applied net recharge was $666 \mathrm{ft}^{3} / \mathrm{s}$. Predevelopment recharge from the source-sink layer was $574 \mathrm{ft}^{3} / \mathrm{s}$. Simulated predevelopment discharge to regional drains occurred at the rate of $826 \mathrm{ft}^{3} / \mathrm{s}$. Corresponding discharge to the source-sink layer and flow to specified heads along downgradient and lateral boundaries were $368 \mathrm{ft}^{3} / \mathrm{s}$ and $57 \mathrm{ft}^{3} / \mathrm{s}$, respectively. These discharges agreed closely with independently derived elements of a subregional water budget.

Simulations of transient conditions were accomplished for the period $1900-80$ by using five stress periods1900-44, 1945-60, 1961-70, 1971-75, and 1976-80. Pumpage for each stress period represented estimates of net withdrawal for industrial, municipal, and agricultural purposes; pumpage increased substantially with each stress period. Total mean annual pumpage for the period $1976-80$ was $375 \mathrm{ft}^{3} / \mathrm{s}$. Mean annual pumpage for the period $1900-44$ was about $16 \mathrm{ft}^{3} / \mathrm{s}$.

Storativity values used in the transient simulations ranged from about 0.008 to 0.0001 . Storativity generally decreased seaward of areas of outcrop.

After 80 years of simulated ground-water pumping, ground-water discharge to regional drains was reduced 
to about $670 \mathrm{ft}^{3} / \mathrm{s}$, about 19 percent below predevelopment rates. Related reductions in aquifer storage were about $22 \mathrm{ft}^{3} / \mathrm{s}$. Simulated downward leakage from the Barnwell-Upper Floridan aquifer increased 27 percent over the predevelopment rate to $725 \mathrm{ft}^{3} / \mathrm{s}$. Corresponding upward leakage to the Barnwell-Upper Floridan aquifer was about $430 \mathrm{ft}^{3} / \mathrm{s}$ during 1980 . Net boundary discharges decreased from $44 \mathrm{ft}^{3} / \mathrm{s}$ out of the model to about $3 \mathrm{ft}^{3} / \mathrm{s}$ into the model. Simulated rates of net recharge during transient simulations were maintained at the predevelopment rate of $666 \mathrm{ft}^{3} / \mathrm{s}$.

Major areas of water-level declines were simulated in the shallower aquifers and included substantial drawdowns in the Tallahatta-Gordon aquifer in southeastern Georgia and drawdowns in the Clayton-Ellenton aquifer in Houston County, Ala.; in the vicinity of Albany in southwestern Georgia; and in northern Hampton County, S.C. Areas of substantial water-level declines near Albany, Ga., also were simulated for the TallahattaGordon and Providence Sand-Peedee aquifers. Smaller areas of water-level declines were simulated relative to aquifers in Cretaceous sediments in east-central and southwestern Georgia. A small area of decline was simulated in the vicinity of Georgetown in southwestern Georgia, relative to the upper Atkinson-upper Tuscaloosa aquifer. The simulated and observed predevelopment and 1980 potentiometric data generally agreed to within $\pm 20 \mathrm{ft}$.

Sensitivity of predevelopment (steady-state) and transient simulations was evaluated by using root mean square error and by uniformly varying leakance, transmissivity, recharge, and storativity by factors of 0.5 , 2.0 , and 10.0. Simulations of head values and budget components were most sensitive to changes in recharge and transmissivity and least sensitive to changes in storativity.

\section{REFERENCES CITED}

Applin, E.R., 1955, A biofacies of Woodbine age in the southeastern Gulf Coast region: U.S. Geological Survey Professional Paper 264-I, p. I187-I197.

Applin, E.R., and Applin, P.L., 1964, Logs of selected wells in the Coastal Plains of Georgia: Georgia Geological Survey Bulletin 74, $229 \mathrm{p}$.

Applin, P.L., and Applin, E.R., 1947, Regional subsurface stratigraphy, structure, and correlation of middle and early Upper Cretaceous rocks in Alabama, Georgia, and north Florida: U.S. Geological Survey Oil and Gas Investigations Preliminary Chart 26, 3 sheets.

1967, The Gulf series in the subsurface in northern Florida and southern Georgia: U.S. Geological Survey Professional Paper 524-G, $34 \mathrm{p}$.

Aucott, W.R., 1988, The predevelopment ground-water flow system and hydrologic characteristics of the Coastal Plain aquifers of South Carolina: U.S. Geological Survey Water-Resources Investigations Report 86-4347, $66 \mathrm{p}$.
Aucott, W.R., Davis, M.E., and Speiran, G.K., 1987, Geohydrologic framework of the Coastal Plain aquifers of South Carolina: U.S. Geological Survey Water-Resources Investigations Report 85-4271, 7 plates.

Baker, R.M., Gillett, B., and Meng, P.M., 1982, Use of water in Alabama, 1980: Alabama Geological Survey Information Series 59, $50 \mathrm{p}$.

Barker, R.A., 1986, Preliminary results of a steady-state ground-water flow model of the Southeastern Coastal Plain regional aquifer system, in Proceedings of the Southern Regional Ground Water Conference, September 18-19, 1985, San Antonio, Texas: Association of Ground Water Scientists and Engineers, Division of the National Water Well Association, p. 315-338.

Behrendt, J.C., Hamilton, R.M., Ackermann, H.D., and Henry, V.J., 1981, Cenozoic faulting in the vicinity of the Charleston, South Carolina, 1886 earthquake: Geology, v. 9, no. 3, p. 117-122.

Bennett, C.S., Hayes, R.D., Gissendanner, J.W., and Herlong, H.E., 1983, Water resources data, South Carolina water year 1982: U.S. Geological SurveyWater-Data Report SC-82-1, 330 p.

Bingham, R.H., 1982, Low-flow characteristics of Alabama streams: U.S. Geological Survey Water-Supply Paper 2083, 27 p.

Brooks, Rebekah, Clarke, J.S., and Faye, R.E., 1985, Hydrogeology of the Gordon aquifer system of east-central Georgia: Georgia Geologic Survey Information Circular 75, $41 \mathrm{p}$.

Brown, P.M., Brown, D.L., Reid, M.S., and Lloyd, O.B., Jr., 1979 , Evaluation of the geologic and hydrologic factors related to the waste-storage potential of Mesozoic aquifers in the southern part of the Atlantic Coastal Plain, South Carolina and Georgia: U.S. Geological Survey Professional Paper 1088, 37p.

Buie, B.F., 1978, The Huber Formation of eastern central Georgia: Georgia Geological Survey Bulletin 93, p. 1-7.

Buie, B.F., Hetrick, J.H., Patterson, S.H., and Neeley, C.L., 1979, Geology and industrial mineral resources of the Macon-Gordon kaolin district, Georgia: U.S. Geological Survey Open-File Report 79-526, $36 \mathrm{p}$.

Cahill, J.M., 1982, Hydrology of the low-level radioactive solid waste burial site and vicinity near Barnwell, South Carolina: U.S. Geological Survey Open-File Report 82-863, 109p.

Callahan, J.T., 1964, The yield of sedimentary aquifers of the Coastal Plain, Southeast River Basins: U.S. Geological Survey WaterSupply Paper 1669-W, $56 \mathrm{p}$.

Carlston, C.W., 1944, Ground-water resources of the Cretaceous area of Alabama: Alabama Geological Survey Special Report 18, 203 p.

Carter, R.F., and Johnson, A.M.F., 1974, Use of water in Georgia, 1970, with projections to 1990: Georgia, Earth and Water Division, Water Resources Survey Hydrologic Report 2, $74 \mathrm{p}$.

Carter, R.F., and Stiles, H.R., 1983, Average annual rainfall and runoff in Georgia, 1941-70: Georgia Geologic Survey Hydrologic Atlas 9, 2 sheets, scale 1:500,000.

Carter, R.W., and Williams, M.R., 1949, Water resources and hydrology of southeastern Alabama: Alabama Geological Survey Special Report 20, $265 \mathrm{p}$.

Charm, W.B., Nesteroff, W.D., and Valdes, S., 1969, Detailed stratigraphic description of the JOIDES cores on the continental margin off Florida: U.S. Geological Survey Professional Paper 581-D, $13 \mathrm{p}$.

Chowns, T.M., and Williams, C.T., 1983, Pre-Cretaceous rocks beneath the Georgia Coastal Plain-Regional implications, in Gohn, G.S., ed., Studies related to the Charleston, South Carolina, earthquake of 1886-Tectonics and seismicity: U.S. Geological Survey Professional Paper 1313, p. L1-L42.

Christl, R.J., 1964, Storage of radioactive wastes in basement rock beneath the Savannah River Plant: E.I. DuPont De Nemours \& Company Report DP-844, 105 p. 
Christopher, R.A., 1982a, Palynostratigraphy of the basal Cretaceous units of the eastern Gulf and southern Atlantic Coastal Plains, in Arden, D.D., Beck, B.F., and Morrow, Eleanore, eds., Second symposium on the geology of the Southeastern Coastal Plain: Georgia Geologic Survey Information Circular 53, p. 10-23.

- 1982b, The occurrence of the Complexiopollis-Atlantopollis zone (palynomorphs) in the Eagleford Group (Upper Cretaceous) of Texas: Journal of Paleontology, v. 56, no. 2, p. 525-541.

Clark, L.D., 1965, Bauxite deposits of the Springvale District (Randolph and Quitman Counties) Georgia: U.S. Geological Survey Bulletin 1199-F, p. F1-F24.

Clarke, J.S., Faye, R.E., and Brooks, Rebekah, 1983, Hydrogeology of the Providence aquifer of southwest Georgia: Georgia Geologic Survey Hydrologic Atlas 11, 5 sheets, scale 1:1,000,000.

-1984 , Hydrogeology of the Clayton aquifer of southwest Georgia: Georgia Geologic Survey Hydrologic Atlas 13, 6 sheets.

-1985, Hydrogeology of the Dublin and Midville aquifer systems of east-central Georgia: Georgia Geologic Survey Information Circular 74, $62 \mathrm{p}$.

Cofer, H.E., Jr., and Frederiksen, N.O., 1982, Paleoenvironment and age of kaolin deposits in Andersonville, Georgia district, in Arden, D.D., ed., Second symposium on the geology of the Southeastern Coastal Plain: Georgia Geological Survey Information Circular 53, p. 24-37.

Cofer, H.E., Jr., and Manken, J.P., 1983, Geology and resources of the Andersonville, Georgia, kaolin and bauxite district: U.S. Geological Survey Open-File Report 83-580, $95 \mathrm{p}$.

Colquhoun, D.J., Oldham, R.W., Bishop, J.W., and Howell, P.D., 1982, Updip delineation of the Tertiary Limestone aquifer, South Carolina: U.S. Department of Interior, Office of Water Policy Report 97, 93 p.

Cooke, C.W., 1936, Geology of the Coastal Plain of South Carolina: U.S. Geological Survey Bulletin 867, $196 \mathrm{p}$.

1943, Geology of the Coastal Plain of Georgia: U.S. Geological Survey Bulletin 941, $121 \mathrm{p}$.

Cooke, C.W., and MacNeil, F.S., 1952, Tertiary stratigraphy of South Carolina: U.S. Geological Survey Professional Paper 120, p. 19-29.

Counts, H.B., and Donsky, Ellis, 1963, Salt-water encroachment, geology and ground-water resources of Savannah area, Georgia and South Carolina: U.S. Geological Survey Water-Supply Paper $1611,100 \mathrm{p}$.

Counts, H.B., and Krause, R.E., 1976, Digital model analysis of the principal artesian aquifer, Savannah, Georgia area: U.S. Geological Survey Water-Resources Investigations Report 76-133, 4 sheets.

Daniel, J.F., 1976, Estimating ground-water evapotranspiration from streamflow records: Water Resources Research, v. 12, no. 3, p. $360-364$.

Davis, M.E., 1980, Ground-water levels in Alabama: Alabama Geological Survey Circular 105, 74 p.

Eargle, D.H., 1955, Stratigraphy of the outcropping Cretaceous rocks in Georgia: U.S. Geological Survey Bulletin 1014, 101 p.

Faye, R.E., and Mayer, G.C., 1988, Ground-water flow and streamaquifer relations in the northern Coastal Plain of Georgia and adjacent parts of Alabama and South Carolina: U.S. Geological Survey Water-Resources Investigations Report 88-4143, $85 \mathrm{p}$.

Faye, R.E., and McFadden, K.W., 1986, Hydraulic characteristics of Upper Cretaceous and lower Tertiary clastic aquifers-Eastern Alabama, Georgia, and western South Carolina: U.S. Geological Survey Water-Resources Investigations Report 86-4210, 22 p.

Faye, R.E., and Prowell, D.C., 1982, Effects of Late Cretaceous and Cenozoic faulting on the geology and hydrology of the Coastal Plain near the Savannah River, Georgia and South Carolina: U.S. Geological Survey Open-File Report 82-156, 73 p.
Frazier, W.J., 1982, Sedimentology and paleoenvironmental analysis of the Upper Cretaceous, Tuscaloosa, and Eutaw Formations in western Georgia, in Arden, D.D., Beck, B.F., and Morrow, Eleanore, eds., Second symposium on the geology of the Southeastern Coastal Plain: Georgia Geologic Survey Information Circular 53, p. 39-52.

Frazier, W.J., and Taylor, R.S., 1980, Facies changes and paleogeographic interpretations of Eutaw Formation (Upper Cretaceous) from western Georgia to central Alabama, in Tull, J.F., ed., Field trips for the southeastern section of the Geological Society of America, Birmingham, Alabama, p. 1-27.

Frederiksen, N.O., 1980, Lower Tertiary sporomorph biostratigraphy: preliminary report, in Frey, R.W., ed., Excursions in southeastern geology, v. II: Geological Society of America and American Geological Institute Guidebook, p. 422-423.

Freeze, R.A., 1966, Theoretical analysis of regional ground water flow: Berkeley, Calif., University of California, unpublished Ph.D. thesis, $304 \mathrm{p}$.

Freeze, R.A., and Witherspoon, P.A., 1966, Theoretical analysis of regional ground water flow-1. Analytical and numerical solutions to the mathematical model: Water Resources Research, v. 2, no. 4, p. $641-656$.

-1967, Theoretical analysis of regional ground water flow-2. Effect of water-table configuration and subsurface permeability variation: Water Resources Research, v. 3, no. 2, p. 623-634.

Gelbaum, C.S., and Howell, J., 1982, The geohydrology of the Gulf trough-A preliminary investigation, in Arden, D.D., Beck, B.F., and Morrow, Eleanore, eds., Second symposium on the geology of the Southeastern Coastal Plain: Georgia Geologic Survey Information Circular 53, p. 140-153.

Georgia Department of Natural Resources, 1976, Geologic map of Georgia: Atlanta, Ga., l sheet, scale 1:500,000.

Gibson, T.G., 1980a, Facies changes of lower Paleocene strata, in Upper Cretaceous and lower Tertiary geology of the Chattahoochee River Valley, western Georgia and eastern Alabama, in Frey, R.W., ed., Excursions in southeastern geology, v. II: Geological Society of America and American Geological Institute Guidebook, p. 402-411.

$1980 \mathrm{~b}$, Molluscan and foraminiferal biostratigraphy and lower Paleocene strata, in Frey, R.W., ed., Excursions in southeastern geology, v. II: Geological Society of America and American Geological Institute Guidebook, p. 411-416.

1982a, New stratigraphic unit in the Wilcox Group (upper Paleocene-lower Eocene) in Alabama and Georgia: U.S. Geological Survey Bulletin 1529-H, p. 23-32.

1982b, Paleocene to middle Eocene depositional cycles in eastern Alabama and western Georgia, in Arden, D.D., Beck, B.F., and Morrow, Eleanore, eds., Second symposium on the geology of the Southeastern Coastal Plain: Georgia Geologic Survey Information Circular 53, p. 53-63.

Gibson, T.G., Edwards, L.E., and Frederiksen, N.O., 1980, Biological interpretation of depositional environments in lower Paleocene strata, in Frey, R.W., ed., Excursions in southeastern geology, v. II: Geological Society of America and American Geological Institute Guidebook, p. 428-431.

Gohn, G.S., 1983, Geology of the basement rocks near Charleston, South Carolina-Data from detrital rock fragments in lower Mesozoic(?) rocks in Clubhouse Crossroads Test Hole \#3, in Gohn, G.S., ed., Studies related to the Charleston, South Carolina, earthquake of 1886-Tectonics and seismicity: U.S. Geological Survey Professional Paper 1313, p. E1-E22.

Gohn, G.S., Bybell, L.M., Christopher, R.A., Owens, J.P., and Smith, C.C., 1982, A stratigraphic framework for Cretaceous and Paleogene sediments along the South Carolina and Georgia coastal margins, in Arden, D.D., Beck, B.F., and Morrow, Eleanore, 
eds., Second symposium on the geology of the Southeastern Coastal Plain: Georgia Geologic Survey Information Circular 53, p. 64-74.

Gohn, G.S., Bybell, L.M., Smith, C.C., and Owens, J.P., 1980, Preliminary stratigraphic cross sections of Atlantic Coastal Plain sediments of the Southeastern United States-Cenozoic sediments along the South Carolina coastal margin: U.S. Geological Survey Miscellaneous Field Studies Map MF-1015-B.

Gohn, G.S., Christopher, R.A., Smith, C.C., and Owens, J.P., 1978, Preliminary stratigraphic cross sections of the Atlantic Coastal Plain sediments of the Southeastern United States-Cretaceous sediments along the South Carolina coastal margin: U.S. Geological Survey Miscellaneous Field Studies Map MF-1015-A.

Gohn, G.S., Hazel, J.E., Bybell, L.M., and Edwards, L.E., 1983, The Fishburne Formation (lower Eocene), a newly defined subsurface unit in the South Carolina Coastal Plain: U.S. Geological Survey Bulletin 1537-C, $16 \mathrm{p}$.

Gohn, G.S., Higgins, B.A., Smith, C.C., and Owens, J.P., 1977, Lithostratigraphy of the deep corehole (Clubhouse Crossroads corehole 1) near Charleston, South Carolina, in Rankin, D.W., ed., Studies related to the Charleston, South Carolina, earthquake of 1886-A preliminary report: U.S. Geological Survey Professional Paper 1028-E, p. 59-70.

Gohn, G.S., Houser, B.B., and Schneider, R.R., 1983, Geology of the lower Mesozoic(?) sedimentary rocks in Clubhouse Crossroads Test Hole \#3, near Charleston, South Carolina, in Gohn, G.S., ed., Studies related to the Charleston, South Carolina, earthquake of 1886-Tectonics and seismicity: U.S. Geological Survey Professional Paper 1313, p. D1-D17.

Gohn, G.S., Smith, C.C., Christopher, R.A., and Owens, J.P., 1980, Preliminary stratigraphic cross sections of Atlantic Coastal Plain sediments along the Georgia coastal margin: U.S. Geological Survey Miscellaneous Field Studies Map MF-1015-C, 2 sheets.

Gorday, L.L., 1985, The hydrogeology of the Coastal Plain strata of Richmond and northern Burke Counties, Georgia: Georgia Geologic Survey Information Circular 61, $43 \mathrm{p}$.

Hack, J.T., 1982, Physiographic divisions and differential uplift in the Piedmont and Blue Ridge: U.S. Geological Survey Professional Paper $1265,49 \mathrm{p}$.

Hayes, L.R., 1979, The ground-water resources of Beaufort, Colleton, Hampton, and Jasper Counties, South Carolina: South Carolina Water Resources Commission Report 9, $91 \mathrm{p}$.

Hazel, J.E., 1969, Cythereis eaglefordensis Alexander, 1929-A guide fossil for deposits of latest Cenomanian age in the western interior and Gulf Coast regions of the United States: U.S. Geological Survey Professional Paper 650-D, p. D155-D158.

Hazel, J.E., and Brouwers, E.M., 1982, Biostratigraphic and chronostratigraphic distribution of ostracodes in the ConiacianMaastrichtian (Austinian-Navarroan) in the Atlantic and Gulf Coastal province, in Maddocks, R.E., ed., Texas OstracodaGuidebook of excursions and related papers for the Eighth Annual International Symposium on Ostracoda: Houston, Tex., University of Texas, Department of Geosciences, p. 166-198.

Hazel, J.E., Bybell, L.M., Christopher, R.A., Fredericksen, N.O., May, F.E., McLean, D.M., Poore, R.Z., Smith, C.C., Sohl, N.F., Valentine, P.C., and Witmer, R.J., 1977, Biostratigraphy of the deep corehole (Clubhouse Crossroads corehole 1) near Charleston, South Carolina, in Rankin, D.W., ed., Studies related to the Charleston, South Carolina, earthquake of $1886-$ A preliminary report: U.S. Geological Survey Professional Paper 1028-F, p. $71-89$.

Hazel, J.E., Edwards, L.F., and Bybell, L.M., 1984, Significant unconformities and hiatuses represented by them in the Paleogene of the Atlantic and Gulf Coastal province: American Association of Petroleum Geologists Memoir 36, p. 59-66.
Herrick, S.M., 1961, Well logs of the Coastal Plain of Georgia: Georgia Geological Survey Bulletin 70, 462 p.

1972, Age and correlation of the Clinchfield Sand in Georgia: U.S. Geological Survey Bulletin 1354-E, p. 1-17.

Herrick, S.M., and Counts, H.B., 1968, Late Tertiary stratigraphy of eastern Georgia: Georgia Geological Society Guidebook, Field Trip $3,88 \mathrm{p}$.

Hester, N.C., 1968, The origin of the Cusseta Sand: Cincinnati, University of Cincinnati, unpublished Ph.D. thesis, $219 \mathrm{p}$.

Hicks, D.W., Krause, R.E., and Clarke, J.S., 1981, Geohydrology of the Albany area, Georgia: Georgia Geologic Survey Information Circular 57, $31 \mathrm{p}$.

Hitchon, B., 1969, Fluid flow in the western Canada sedimentary basin: Water Resources Research, v. 5, no. 1, p. 186-195.

Huddlestun, P.F., 1982, The development of the stratigraphic terminology of the Claibornian and Jacksonian marine deposits of western South Carolina and eastern Georgia, in Nystrum, P.G., Jr., and Willoughby, R.H., eds., Geological investigations related to the stratigraphy in the kaolin mining district, Aiken County, South Carolina: Carolina Geological Society Field Trip Guidebook, p. 21-23.

Huddlestun, P.F., and Hetrick, J.H., 1978, Stratigraphy of the Tobacco Road Sand-A new formation: Georgia Geological Survey Bulletin 93, p. 56-77.

1979, The stratigraphy of the Barnwell Group of Georgia: Georgia Geological Survey Open-File Report 80-1, $89 \mathrm{p}$.

1982, Upper Eocene stratigraphy of eastern Georgia, in Arden, D.D., Beck, B.F., and Morrow, Eleanore, eds., Second symposium on the geology of the Southeastern Coastal Plain [abs.]: Georgia Geologic Survey Information Circular 53, p. 75.

Huddlestun, P.F., Marsalis, W.E., and Pickering, S.M., Jr., 1974, Tertiary stratigraphy of the central Georgia Coastal Plain: Geological Society of America Guidebook, 12th Annual Field Trip, $35 \mathrm{p}$.

Johnston, R.H., Healy, H.G., and Hayes, L.R., 1981, Potentiometric surface of the Tertiary limestone aquifer system, Southeastern United States, May 1980: U.S. Geological Survey Open-File Report 81-486, 1 sheet, scale 1:1,000,000.

Johnston, R.H., Krause, R.E., Meyer, R.W., Ryder, P.D., Tibbals, C.H., and Hunn, J.D., 1980, Estimated potentiometric surface for the Tertiary limestone aquifer system, Southeastern United States, prior to development: U.S. Geological Survey Open-File Report 80-406, 1 sheet, scale 1:1,000,000.

Krause, R.E., and Randolph, R.B., 1989, Hydrology of the Floridan aquifer system in southeast Georgia and adjacent parts of Florida and South Carolina: U.S. Geological Survey Professional Paper 1403-D, $65 \mathrm{p}$.

LaMoreaux, P.E., 1946, Geology and ground-water resources of the Coastal Plain of east-central Georgia: Georgia Geological Survey Bulletin 52, $173 \mathrm{p}$.

Laney, R.L., and Davidson, C.B., 1986, Aquifer nomenclature guidelines: U.S. Geological Survey Open-File Report 86-534, 46 p.

LeGrand, H.E., 1961, Summary of geology of Atlantic Coastal Plain: American Association of Petroleum Geologists Bulletin, v. 45, no. 9, p. 1557-1571.

1962, Geology and ground-water resources of the Macon area, Georgia: Georgia Geological Survey Bulletin 72, $68 \mathrm{p}$.

LeGrand, H.E., and Furcron, A.S., 1956, Geology and ground-water resources of central-east Georgia: Georgia Geological Survey Bulletin $64,174 \mathrm{p}$.

LeGrand, H.E., and Pettyjohn, W.A., 1981, Regional hydrogeologic concepts of homoclinal flanks: Groundwater, v. 19, no. 3, p. $303-310$.

Maher, J.C., 1971, Geologic framework and petroleum potential of the Atlantic Coastal Plain and continental shelf, with a section on 
stratigraphy by John C. Maher and Ester R. Applin: U.S. Geological Survey Professional Paper 659, 98 p.

Marine, I.W., 1979, Hydrology of buried crystalline rocks at the Savannah River Plant near Aiken, South Carolina: U.S. Geological Survey Open-File Report 79-1544, $160 \mathrm{p}$.

Marine, I.W., and Siple, G.E., 1974, Buried Triassic basin in the central Savannah River area, South Carolina and Georgia: Geological Society of America Bulletin, v. 85, p. 311-320.

Markewich, H.W., and Christopher, R.A., 1982, Geologic map of the La Place and Tuskegee quadrangles, Macon, Tallapoosa, and Elmore Counties, Alabama: U.S. Geological Survey Miscellaneous Investigations Series Map I-1417, 1 sheet, scale 1:48,000.

Marsalis, W.E., Jr., and Friddell, M.S., 1975, A guide to selected Upper Cretaceous and lower Tertiary outcrops in the lower Chattahoochee River valley of Georgia: Georgia Geological Society Guidebook 15, $85 \mathrm{p}$.

Maslia, M.L., and Hayes, L.R., 1988, Hydrogeology and simulated effects of ground-water development of the Floridan Aquifer System, southwest Georgia, northwest Florida, and southernmost Alabama: U.S. Geological Survey Professional Paper 1403-H, $71 \mathrm{p}$.

McCallie, S.W., 1898, A preliminary report on the artesian well system of Georgia: Geological Survey of Georgia Bulletin 7, $214 \mathrm{p}$.

1908, A preliminary report on the underground waters of Georgia: Geological Survey of Georgia Bulletin 15, $370 \mathrm{p}$.

McCollum, M.J., and Counts, H.B., 1964, Relation of saltwater encroachment to the major aquifer zones, Savannal area, Georgia and South Carolina: U.S. Geological Survey Water-Supply Paper $1613-\mathrm{D}, 26 \mathrm{p}$.

McDonald, M.G., and Harbaugh, A.W., 1984, A modular finitedifference ground-water flow model: U.S. Geological Survey OpenFile Report 83-875, 527 p.

McDowell, R.C., and Houser, B.B, 1983, Distribution of small-scale deformation structures in a part of the upper Coastal Plain of South Carolina and adjacent Georgia: U.S. Geological Survey Miscellaneous Field Studies Map MF-1538.

McFadden, S.S., Hetrick, J.H., Kellam, M.F., Rodenbeck, S.A., and Huddlestun, P.F., 1986, Geologic data of the Gulf trough areas, Georgia: Georgia Geologic Survey Information Circular 56, 345 p.

McLean, J.D., Jr., 1960, Stratigraphy of the Parris Island area, South Carolina: McLean Paleontological Laboratory Report 4 [unpaged].

Miller, J.A., 1982, Structural control of Jurassic sedimentation in Alabama and Florida [abs.], in Arden, D.D., Beck, B.F., and Morrow, Eleanore, eds., Second symposium on the geology of the Southeastern Coastal Plain: Georgia Geologic Survey Information Circular 53, p. 88.

1986, Hydrogeologic framework of the Floridan aquifer system in Florida and parts of Georgia, South Carolina, and Alabama: U.S. Geological Survey Professional Paper 1403-B, 91 p.

Miller, J.A., and Renken, R.A., 1988, Nomenclature of regional hydrogeologic units of the Southeastern Coastal Plain aquifer system: U.S. Geological Survey Water-Resources Investigations Report 87-4202, $21 \mathrm{p}$.

Milton, Charles, and Hurst, V.J., 1965, Subsurface basement rocks of Georgia: Georgia Geological Survey Bulletin 76, $56 \mathrm{p}$.

Moffett, T.B., Baker, R.M., and Richter, K.E., 1985, Reconnaissance of ground-water conditions in southeast Alabama: Alabama Geological Survey Circular 123, $78 \mathrm{p}$.

Newton, J.G., 1965, Geologic map of Barbour County, Alabama: Alabama Geological Survey Map 33, 1 sheet, scale 1:5,280.

-1968a, Geologic map of Dale County, Alabama: Alabama Geological Survey Map 63, 1 sheet, scale 1:10,560.

1968b, Geologic map of Henry County, Alabama: Alabama Geological Survey Map 70, 1 sheet, scale 1:10,560.
Newton, J.G., Golden, H.G., Avrett, J.R., and Scott, J.C., 1968, Water availability map of Dale County, Alabama: Alabama Geological Survey Map 64, 1 sheet, with separate text 26 p., scale $1: 10,560$.

Newton, J.G., McCain, J.F., and Avrett, J.R., 1968, Water availability map of Henry County, Alabama: Alabama Geological Survey Map 71, 1 sheet, with separate text 14 p., scale 1:10,560.

Newton, J.G., Powell, W.J., Golden, H.G., and Avrett, J.R., 1966, Water availability, Barbour County, Alabama: Alabama Geological Survey Map 34, 1 sheet, scale 1:5,280.

Nikravesh, R., 1967, The Foraminifera and paleoecology of the Blufftown Formation of Georgia and eastern Alabama: Baton Rouge, Louisiana State University, unpublished Ph.D. thesis, $159 \mathrm{p}$.

Nystrum, P.G., Jr., and Willoughby, R.H., 1982, Cretaceous, Tertiary, and Pleistocene(?) stratigraphy of Hollow Creek and Graniteville quadrangles, Aiken County, South Carolina, in Nystrum, P.G., Jr., and Willoughby, R.H., eds., Geological investigations related to the stratigraphy in the kaolin mining district, Aiken County, South Carolina: Carolina Geological Society Field Trip Guidebook, p. 80-113.

Oldham, R.W., 1981, Surface to subsurface geology of eastern Aiken, western Orangeburg, northern Bamberg, and northern Barnwell Counties and structural attitude and occurrence of the Black Mingo Formation in the subsurface between the Santee and Savannah Rivers, South Carolina: Columbia, University of South Carolina, unpublished M.S. thesis, $96 \mathrm{p}$.

Overstreet, W.C., and Bell, Henry, III, 1965, Geologic map of the crystalline rocks of South Carolina: U.S. Geological Survey Miscellaneous Geologic Investigations Map I-413, 1 sheet, scale $1: 250,000$

Owen, Vaux, Jr., 1951, The stratigraphy and lithology of Webster County, Georgia: Athens, University of Georgia, unpublished M.S. thesis, $82 \mathrm{p}$.

1959, A summary of ground-water resources of Sumter County, Georgia: Georgia Mineral Newsletter, v. 14, nos. 2-3, p. 41-51.

1963a, Geology and ground-water resources of Mitchell County, southwest Georgia: Georgia Geological Survey Information Circular 24, $40 \mathrm{p}$.

$1963 \mathrm{~b}$, Geology and ground-water resources of Lee and Sumter Counties, southwest Georgia: U.S. Geological Survey WaterSupply Paper 1666, $70 \mathrm{p}$.

Owens, J.P., and Gohn, G.S., 1985, Depositional history of the Cretaceous series in the U.S. Atlantic Coastal Plain-Stratigraphy, paleoenvironments, and tectonic control of sedimentation, in Poag, C.W., ed., Geologic evolution of the United States Atlantic margin: New York, Van Nostrand Reinholdt, p. 25-86.

Owens, J.P., Minard, J.P., Sohl, N.F., and Mello, J.F., 1970, Stratigraphy of the outcropping post-Magothy Upper Cretaceous formations in southern New Jersey and northern Delmarva Peninsula, Delaware, and Maryland: U.S. Geological Survey Professional Paper 674, $60 \mathrm{p}$.

Pessagno, E.A., Jr., 1967, Upper Cretaceous planktonic Foraminifera from the western Gulf Coastal Plain: Paleontographica Americana, v. 5, no. 37 , p. $243-255$.

Pickering, S.M., Jr., 1970, Stratigraphy, paleontology, and economic geology of portions of Perry and Cochran quadrangles, Georgia: Georgia Geological Survey Bulletin 81, $67 \mathrm{p}$.

Pierce, R.R., Barber, N.L., and Stiles, H.R., 1982, Water use in Georgia by county for 1980: Georgia Geologic Survey Information Circular 59, 180 p.

1984, Georgia irrigation, 1970-80-A decade of growth: U.S. Geological Survey Water-Resources Investigations Report 83-4177, 29 p. 
Pooser, W.K., 1965, Biostratigraphy of Cenozoic Ostracoda from South Carolina: University of Kansas Paleontological Contributions-Arthropoda, Article 8, $80 \mathrm{p}$.

Postuma, J.A., 1971, Manual of planktonic Foraminifera: New York, Elsevier Publishing Co., 417 p.

Prowell, D.C., 1983, Index of faults of Cretaceous and Cenozoic age in the Eastern United States: U.S. Geological Survey Miscellaneous Field Studies Map MF-1269, scale 1:2,500,000.

Prowell, D.C., Christopher, R.A., Edwards, L.E., Bybell, L.M., and Gill, H.E., 1985, Geologic section of the updip Coastal Plain of eastern Georgia and western South Carolina: U.S. Geological Survey Miscellaneous Field Studies Map MF-1737, scale 1:160,000.

Prowell, D.C., and O'Conner, B.J., 1978, Belair fault zone-Evidence of Tertiary fault displacement in eastern Georgia: Geology, v. 6, p. $681-684$.

Reinhardt, Juergen, 1980, Upper Cretaceous stratigraphy and depositional environments, in Upper Cretaceous and lower Tertiary geology of the Chattahoochee River valley, western Georgia and eastern Alabama: Geological Society of America Field Trip 20, Guidebook, p. 386-392.

1982, Lithofacies and depositional cycles in Upper Cretaceous rocks, central Georgia to eastern Alabama, in Arden, D.D., Beck, B.F., and Morrow, Eleanore, eds., Second symposium on the geology of the Southeastern Coastal Plain: Georgia Geologic Survey Information Circular 53, p. 89-96.

Renken, R.A., 1984, The hydrogeologic framework for the Southeastern Coastal Plain aquifer system of the United States: U.S. Geological Survey Water-Resources Investigations Report $84-4243,26 \mathrm{p}$

Robertson Research (U.S.) Inc., 1980, Framework for oil and gas occurrence in the Gulf Coast: Tertiary, v. 1,241 p. and pls. 3a, b and $4 \mathrm{a}, \mathrm{b}$.

Sandy, J., Carver, R.E., and Crawford, T.J., 1966, Stratigraphy and economic geology of the Coastal Plain of the central Savannah River area: Geological Society of America, Southeastern Section Guidebook, 3rd Annual Field Trip, 30 p.

Scott, J.C., 1960, Ground-water resources of Macon County, Alabama: Alabama Geological Survey Information Series 16, 95 p.

1961, Geologic map of Bullock County, Alabama: Alabama Geological Survey Map 19, 1 sheet, scale 1:10,560.

-1962a, Ground-water resources of Bullock County, Alabama: Alabama Geological Survey Information Series 29, 120 p.

1962b, Geologic map of Russell County, Alabama: Alabama Geological Survey Map 24, 1 sheet, scale 1:5,280.

1964, Ground-water resources of Russell County, Alabama: Alabama Geological Survey Bulletin 75, $77 \mathrm{p}$.

Scott, J.C., Golden, H.G., and Avrett, J.R., 1968, Water availability map of Geneva County, Alabama: Alabama Geological Survey Map 55,1 sheet, scale 1:10,560.

Scott, J.C., Law, L.R., and Cobb, R.H., 1984, Hydrology of the Tertiary-Cretaceous aquifer system in the vicinity of Fort Rucker Aviation Center, Alabama: U.S. Geological Survey WaterResources Investigations Report 84-4118, 221 p.

Scott, J.C., and Lines, G.C., 1972, Water availability of Lee County, Alabama: Alabama Geological Survey Map 131, 1 sheet, scale $1: 10,560$.

Scott, J.C., McCain, J.F., and Avrett, J.R., 1967, Water availability map of Houston County, Alabama: Alabama Geological Survey Map 59, 1 sheet, scale 1:5,280.

Scrudato, R.J., 1969a, Kaolin and associated sediments of east-central Georgia: Chapel Hill, University of North Carolina, unpublished Ph.D. thesis, $97 \mathrm{p}$.

1969b, Origin of east-central Georgia kaolin deposits: Economic Geology, v. 64 , p. 834 .
Sever, C.W., Jr., 1965a, Ground-water resources and geology of Seminole, Decatur, and Grady Counties, Georgia: U.S. Geological Survey Water-Supply Paper 1809-Q, 30 p.

$1965 \mathrm{~b}$, Ground-water resources of Bainbridge, Georgia: Georgia Geological Survey Information Circular $32,10 \mathrm{p}$.

1966, Reconnaissance of the ground water and geology of Thomas County, Georgia: Georgia Geological Survey Information Circular 34, 14 p.

Shamburger, V.M., Jr., 1968, Geologic map of Pike County, Alabama: Alabama Geological Survey Map 72, 1 sheet, scale 1:10,560.

Shamburger, V.M., Jr., Scott, J.C., Golden, H.G., and Avrett, J.R., 1968, Water availability map of Pike County, Alabama: Alabama Geological Survey Map 73, 1 sheet, with separate text 30 p., scale $1: 10,560$.

Siple, G.E., 1946, Ground-water investigations in South Carolina: South Carolina Research, Planning, and Development Board Bulletin $15,116 \mathrm{p}$.

- [1955?], Geology and ground water in parts of Aiken, Barnwell, and Allendale Counties, South Carolina: unpublished report prepared by the U.S. Geological Survey for the Savannah River Operations Office of the Atomic Energy Commission, $183 \mathrm{p}$.

1959, Guidebook for the South Carolina Coastal Plain field trip of the Carolina Geological Society-November 16-17, 1957: South Carolina State Development Board, Division of Geology Bulletin $24,27 \mathrm{p}$.

1967, Geology and ground water of the Savannah River Plant and vicinity, South Carolina: U.S. Geological Survey WaterSupply Paper 1841, 113 p.

1975, Ground-water resources of Orangeburg County, South Carolina: South Carolina State Development Board, Division of Geology Bulletin 36, 59 p.

Skinner, H.C., and Steinkraus, W.E., 1972, Atlas and catalogue of principal Gulf Coast index Foraminifera, in Skinner, H.C., ed., Gulf Coast stratigraphic correlation methods: New Orleans, Louisiana Heritage Press, p. 81-213.

Smith, E.A., 1904, Notes on the water resources of Alabama: U.S. Geological Survey Water-Supply Paper 102, p. 276-331.

Smith, G.E., III, 1979, Lithostratigraphic relationships of Coastal Plain units in Lexington County and adjacent areas, South Carolina: Columbia, University of South Carolina, unpublished M.S. thesis, $139 \mathrm{p}$.

1980, Preliminary report on the geology of Lexington County, South Carolina: South Carolina Geological Survey Open-File Report 20, $45 \mathrm{p}$.

Snipes, D.S., 1965, Stratigraphy and sedimentation of the Middendorf Formation between Lynches River, South Carolina, and the Ocmulgee River, Georgia: Chapel Hill, University of North Carolina, unpublished Ph.D. thesis, $140 \mathrm{p}$.

Sohl, N.F., and Smith, C.C., 1980, Notes on Cretaceous biostratigraphy, in Frey, R.W., ed., Excursions in southeastern geology, v. II: Geological Society of America and American Geological Institute Guidebook, p. 382-402.

South Carolina State Planning Board, 1944, Natural resources of South Carolina: South Carolina State Planning Board Bulletin 3, p. $36-44$.

South Carolina Water Resources Commission, 1971, Water use in South Carolina-1970: South Carolina Water Resources Commission, $114 \mathrm{p}$.

1977, Municipal and industrial water use in South Carolina (1976): South Carolina Water Resources Commission Report 127, $95 \mathrm{p}$.

1983, South Carolina State Water Assessment: South Carolina Water Resources Commission Report 140, p. 10.

Stainforth, R.M., Lamb, J.L., Lutherbacher, H., Beard, J.H., and Jeffords, R.M., 1975, Cenozoic planktonic foraminiferal zonation 
and characteristics of index forms: University of Kansas Paleontological Contributions, article 62, $162 \mathrm{p}$.

Stephenson, L.W., and Veatch, J.O., 1915, Underground waters of the Coastal Plain of Georgia: U.S. Geological Survey Water-Supply Paper 341, 539 p.

Stewart, J.W., 1973, Dewatering of the Clayton Formation during construction of the Walter F. George lock and dam, Fort Gaines, Clay County, Georgia: U.S. Geological Survey Water-Resources Investigations Report 2-73, $22 \mathrm{p}$.

Stricker, V.A., 1983, Baseflow of streams in the outcrop area of southeastern sand aquifer-South Carolina, Georgia, Alabama, and Mississippi: U.S. Geological Survey Water-Resources Investigations Report 83-4106, $17 \mathrm{p}$.

Stringfield, V.T., 1966, Artesian water in Tertiary limestone in the Southeastern States: U.S. Geological Survey Professional Paper $517,226 \mathrm{p}$.

Sun, R.J., 1986, Introduction, in Sun, R.J., ed., Regional AquiferSystem Analysis Program of the U.S. Geological Survey-Summary of projects, 1978-84: U.S. Geological Survey Circular 1002, p. $1-8$.

Swain, F.M., and Brown, P.M., 1964, Cretaceous Ostracoda from wells in the Southeastern United States: North Carolina Department of Conservation and Development Bulletin 78, $55 \mathrm{p}$.

Thomson, M.T., and Carter, R.F., 1955, Surface water resources of Georgia during the drought of 1954: Georgia Department of Mines and Geology Information Circular 17, $79 \mathrm{p}$.

Thomson, M.T., Herrick, S.M., Brown, Eugene, and others, 1956, The availability and use of water in Georgia: Georgia Department of Mines, Mining, and Geology Bulletin 65, 329 p.

Toth, Jozsef, 1962, A theory of ground-water motion in small drainage basins in central Alberta, Canada: Journal of Geophysical Research, v. 67 , no. 11 , p. $4375-4387$.

1963, A theoretical analysis of ground-water flow in small drainage basins: Journal of Geophysical Research, v. 68 , no. 16, p. $4795-4812$.

Toulmin, L.D., and LaMoreaux, P.E., 1963, Stratigraphy along the Chattahoochee River, connecting link between Atlantic and the Gulf Coastal Plains: American Association of Petroleum Geologists Bulletin, v. 47. no. 3, p. 385-404.

Tschudy, R.H., and Patterson, S.H., 1975, Palynological evidence for Late Cretaceous, Paleocene, and early middle Eocene ages for strata in the kaolin belt, central Georgia: U.S. Geological Survey Journal of Research, v. 3, no. 4, p. 437-445.

U.S. Army Corps of Engineers, 1945a, Apalachicola River system, Chattahoochee River profile: Mobile District, U.S. Army Corps of Engineers File 11-15-2-42.

1945b, Apalachicola River system, Flint River profile: Mobile District, U.S. Army Corps of Engineers File 11-15-8-41.

1949a, Altamaha River basin, Georgia profile II: Savannah District, U.S. Army Corps of Engineers File DAS 301/3. 1949b, Altamaha River basin, Georgia profile III: Savannah

District, U.S. Army Corps of Engineers File DAS 301/4. 1949c, Altamaha River basin, Georgia profile IV: Savannah

District, U.S. Army Corps of Engineers File DAS 301/5.

1949d, Altamaha River basin, Georgia profile V: Savannah

District, U.S. Army Corps of Engineers File DAS 301/6.

1959, Savannah River stream profile: Savannah District, U.S. Army Corps of Engineers File DSR 509.
1965, Savannah River survey-Savannah River below Augusta: Savannah District, U.S. Army Corps of Engineers, File DSR 100138.

1972, Stream mileage tables with drainage areas, Mobile District, U.S. Army Corps of Engineers, 165 p.

U.S. Department of Agriculture, 1982, Southwest Georgia land and water resource cooperative study: main report [variously paged].

-1985 , Southeast Georgia land and water resource cooperative study: main report [variously paged].

U.S. Study Commission-Southeast River Basins, 1963, Plan for development of the land and water resources of the southeast river basins: Hydrology, Appendix 10, $87 \mathrm{p}$.

Valentine, P.C., 1982, Upper Cretaceous subsurface stratigraphy and structure of coastal Georgia and South Carolina: U.S. Geological Survey Professional Paper 1222, $33 \mathrm{p}$.

1984, Turonian (Eaglefordian) stratigraphy of the Atlantic Coastal Plain and Texas: U.S. Geological Survey Professional Paper 1315, $21 \mathrm{p}$.

VanHinte, J.E., 1976, A Cretaceous time scale: American Association of Petroleum Geologists Bulletin, v. 60, no. 4, p. 498-516.

Vincent, H.R., 1982, Geohydrology of the Jacksonian aquifer in central and east-central Georgia: Georgia Geologic Survey Hydrologic Atlas 8, 3 sheets, scale 1:81,231.

Vorhis, R.C., 1972, Geohydrology of Sumter, Dooly, Pulaski, Lee, Crisp, and Wilcox Counties, Georgia: U.S. Geological Survey Hydrologic Atlas HA-435, 2 sheets, scale 1:40,229.

Wait, R.L., 1960a, Summary of the ground-water resources of Calhoun County, Georgia: Georgia Mineral Newsletter, v. 13, no. 1 , p. 26-31.

$1960 \mathrm{~b}$, Summary of the geology and ground-water resources of Clay County, Georgia: Georgia Mineral Newsletter, v. 13, no. 2, p. 93-101.

1960c, Summary of the ground-water resources of Terrell County, Georgia: Georgia Mineral Newsletter, v. 13, no. 3, p. $117-122$.

1963, Geology and ground-water resources of Dougherty County, Georgia: U.S. Geological Survey Water-Supply Paper 1539-P, $102 \mathrm{p}$.

Warren, M.A., 1945, Artesian water in southeastern Georgia: Georgia Geological Survey Bulletin 49-A, 83 p.

Warren, W.C., and Clark, L.D., 1965, Bauxite deposits of the Eufaula district, Alabama: U.S. Geological Survey Bulletin 1199-E, 31 p.

Watson, T.W., 1981, Geohydrology of the Dougherty Plain and adjacent area, southwest Georgia: Georgia Geological Survey Hydrologic Atlas 5, 4 sheets.

Wentworth, C.M., and Mergner-Keefer, Marcia, 1983, Regenerate faults of small Cenozoic offset-Probable earthquake sources in the southeastern United States, in Gohn, G.S., ed., Studies related to the Charleston, South Carolina, earthquake of 1886-Tectonics and seismicity: U.S. Geological Survey Professional Paper 1313, p. S1-S20.

Winter, T.C., 1976, Numerical simulation analysis of the interaction of lakes and ground water: U.S. Geological Survey Professional Paper 1001, $45 \mathrm{p}$.

Zapp, A.D., 1965, Bauxite deposits of the Andersonville district, Georgia: U.S. Geological Survey Bulletin 1199-G, p. G1-G37.

Zapp, A.D., and Clark, L.D., 1965, Bauxite in areas adjacent to and between the Springvale and Andersonville districts, Georgia: U.S. Geological Survey Bulletin 1199-H, p. H1-H10. 


is U. S. GOVERNMENT PRINTING OFFICE: $1997-548-646$ 


\section{SELECTED SERIES OF U.S. GEOLOGICAL SURVEY PUBLICATIONS}

\section{Periodical}

Preliminary Determination of Epicenters (issued monthly).

\section{Technical Books and Reports}

Professional Papers are mainly comprehensive scientific reports of wide and lasting interest and importance to professional scientists and engineers. Included are reports on the results of resource studies and of topographic, hydrologic, and geologic investigations. They also include collections of related papers addressing different aspects of a single scientific topic.

Bulletins contain significant data and interpretations that are of lasting scientific interest but are generally more limited in scope or geographic coverage than Professional Papers. They include the results of resource studies and of geologic and topographic investigations, as well as collections of short papers related to a specific topic.

Water-Supply Papers are comprehensive reports that present significant interpretive results of hydrologic investigations of wide interest to professional geologists, hydrologists, and engineers. The series covers investigations in all phases of hydrology, including hydrogeology, availability of water, quality of water, and use of water.

Circulars present administrative information or important scientific information of wide popular interest in a format designed for distribution at no cost to the public. Information is usually of short-term interest.

Water-Resources Investigations Reports are papers of an interpretive nature made available to the public outside the formal USGS publications series. Copies are reproduced on request unlike formal USGS publications, and they are also available for public inspection at depositories indicated in USGS catalogs.

Open-File Reports include unpublished manuscript reports, maps, and other material that are made available for public consultation at depositories. They are a nonpermanent form of publication that may be cited in other publications as sources of information.

\section{Maps}

Geologic Quadrangle Maps are multicolor geologic maps on topographic bases in 7.5- or 15-minute quadrangle formats (scales mainly $1: 24,000$ or 1:62,500) showing bedrock, surficial, or engineering geology. Maps generally include brief texts; some maps include structure and columnar sections only.

Geophysical Investigations Maps are on topographic or planimetric bases at various scales; they show results of surveys using geophysical techniques, such as gravity, magnetic, seismic, or radioactivity, which reflect subsurface structures that are of economic or geologic significance. Many maps include correlations with the geology.

Miscellaneous Investigations Series Maps are on planimetric or topographic bases of regular and irregular areas at various scales; they present a wide variety of format and subject matter. The series also includes 7.5-minute quadrangle photogeologic maps on planimetric bases that show geology as interpreted from aerial photographs. Series also includes maps of Mars and the Moon.
Coal Investigations Maps are geologic maps on topographic or planimetric bases at various scales showing bedrock or surficial geology, stratigraphy, and structural relations in certain coalresource areas.

Oil and Gas Investigations Charts show stratigraphic information for certain oil and gas fields and other areas having petroleum potential.

Miscellaneous Field Studies Maps are multicolor or blackand-white maps on topographic or planimetric bases for quadrangle or irregular areas at various scales. Pre-1971 maps show bedrock geology in relation to specific mining or mineral-deposit problems; post-1971 maps are primarily black-and-white maps on various subjects such as environmental studies or wilderness mineral investigations.

Hydrologic Investigations Atlases are multicolored or blackand-white maps on topographic or planimetric bases presenting a wide range of geohydrologic data of both regular and irregular areas; principal scale is $1: 24,000$, and regional studies are at $1: 250,000$ scale or smaller.

\section{Catalogs}

Permanent catalogs, as well as some others, giving comprehensive listings of U.S. Geological Survey publications are available under the conditions indicated below from the U.S. Geological Survey, Information Services, Box 25286, Federal Center, Denver, CO 80225. (See latest Price and Availability List.)

"Publications of the Geological Survey, 1879-1961" may be purchased by mail and over the counter in paperback book form and as a set of microfiche.

"Publications of the Geological Survey, 1962-1970" may be purchased by mail and over the counter in paperback book form and as a set of microfiche.

"Publications of the U.S. Geological Survey, 1971-1981" may be purchased by mail and over the counter in paperback book form (two volumes, publications listing and index) and as a set of microfiche.

Supplements for 1982, 1983, 1984, 1985, 1986, and for subsequent years since the last permanent catalog may be purchased by mail and over the counter in paperback book form.

State catalogs, "List of U.S. Geological Survey Geologic and Water-Supply Reports and Maps For (State)," may be purchased by mail and over the counter in paperback booklet form only.

"Price and Availability List of U.S. Geological Survey Publications," issued annually, is available free of charge in paperback booklet form only.

Selected copies of a monthly catalog "New Publications of the U.S. Geological Survey" are available free of charge by mail or may be obtained over the counter in paperback booklet form only. Those wishing a free subscription to the monthly catalog "New Publications of the U.S. Geological Survey" should write to the U.S. Geological Survey, 582 National Center, Reston, VA 20192.

Note-Prices of Government publications listed in older catalogs, announcements, and publications may be incorrect. Therefore, the prices charged may differ from the prices in catalog̀s, announcements, and publications. 